\title{
ASIAN DEVELOPMENT OUTLOOK FORECAST ACCURACY 2007-2016
}

Benno Ferrarini

NO. 568

January 2019
ADB ECONOMICS WORKING PAPER SERIES 


\section{Asian Development Outlook Forecast Accuracy 2007-2016}

\section{Benno Ferrarini}

No. 568 | January 2019
Benno Ferrarini (bferrarini@adb.org) is a Senior Economist in the Economic Research and Regional Cooperation Department (ERCD) of the Asian Development Bank.

The author is grateful to Marthe Hinojales for research assistance, and to Heili Bravo for support with editing and document conversion from LaTeX to MS Word. ERCD seminar participants and colleagues who provided valuable comments on an earlier draft are also acknowledged. 
(C) 2019 Asian Development Bank 6 ADB Avenue, Mandaluyong City, 1550 Metro Manila, Philippines

Tel +632632 4444; Fax +6326362444

www.adb.org

Some rights reserved. Published in 2019.

ISSN 2313-6537 (print), 2313-6545 (electronic)

Publication Stock No. WPS199903-2

DOI: http://dx.doi.org/10.22617/WPS199903-2

The views expressed in this publication are those of the authors and do not necessarily reflect the views and policies of the Asian Development Bank (ADB) or its Board of Governors or the governments they represent.

ADB does not guarantee the accuracy of the data included in this publication and accepts no responsibility for any consequence of their use. The mention of specific companies or products of manufacturers does not imply that they are endorsed or recommended by ADB in preference to others of a similar nature that are not mentioned.

By making any designation of or reference to a particular territory or geographic area, or by using the term "country" in this document, $A D B$ does not intend to make any judgments as to the legal or other status of any territory or area.

This work is available under the Creative Commons Attribution 3.0 IGO license (CC BY 3.0 IGO)

https://creativecommons.org/licenses/by/3.o/igo/. By using the content of this publication, you agree to be bound by the terms of this license. For attribution, translations, adaptations, and permissions, please read the provisions and terms of use at https://www.adb.org/terms-use\#openaccess.

This CC license does not apply to non-ADB copyright materials in this publication. If the material is attributed to another source, please contact the copyright owner or publisher of that source for permission to reproduce it. $\mathrm{ADB}$ cannot be held liable for any claims that arise as a result of your use of the material.

Please contact pubsmarketing@adb.org if you have questions or comments with respect to content, or if you wish to obtain copyright permission for your intended use that does not fall within these terms, or for permission to use the ADB logo.

Notes:

In this publication, “\$” refers to United States dollars.

Corrigenda to ADB publications may be found at http://www.adb.org/publications/corrigenda. 


\section{CONTENTS}

TABLES AND FIGURES

ABSTRACT $v$ V

$\begin{array}{lll}\text { I. INTRODUCTION } & 1\end{array}$

II. FORECAST ERRORS AND MEASURES OF ACCURACY 1

III. THE DATA: ASIAN DEVELOPMENT OUTLOOK AND WORLD 3 ECONOMIC OUTLOOK GROWTH AND INFLATION FORECASTS

IV. ASIAN DEVELOPMENT OUTLOOK COMPARATIVE FORECAST ACCURACY 6

A. Asia-43-Gross Domestic Product Growth Forecasts 6

B. Asia-43-Consumer Price Index Inflation Forecasts $\quad 15$

C. Asia-43-Are Growth Forecasts Overly Optimistic? 16

D. Asia-11-Growth and Inflation Forecasts 17

E. G3-Euro Area, Japan, and the United States Growth Forecasts 20

$\begin{array}{lll}\text { V. CONCLUSIONS } & 21\end{array}$

APPENDIXES $\quad 22$

Appendix 1: Asia-43 Growth and Inflation Forecast Errors 22

Appendix 2: G3 Growth Forecast Errors, 2007-2016 30

Appendix 3: Growth and Inflation Count Scores 31

Appendix 4: Asia-43-Gross Domestic Product Forecast Optimism, 2011-2016 34

Appendix 5: Asia-43 Forecast Errors and Brier Scores by Years 38

Appendix 6: Asia-43 Forecast Errors and Brier Scores by Economies 40

Appendix 7: Asia-11 Growth and Inflation Forecast Errors by Economies, Reports, and Years 44

Appendix 8: G3 Growth and Inflation Forecast Errors

Appendix 9: ADO Quarterly Updated GDP Forecast Errors, 2013-2016 Averages 58

$\begin{array}{ll}\text { REFERENCES } & 59\end{array}$ 


\section{TABLES AND FIGURES}

\section{TABLES}

$1 \quad$ Country Years with Growth and Inflation Data Available in All the Reports 4

22010 Growth and Inflation Data Sourcing Example

3 Asia-43 and Asia-11 Average Forecast Errors by Report, Across Countries, and Years 7

$4 \quad$ G3 Average Forecast Errors by Report and Periods 8

5 Asia-43 Gross Domestic Product Forecast Optimism, 2011-2016 16

6 Score Board 18

$7 \quad$ Asia-11, Brier, and Count Scores 19

8 G3 Gross Domestic Product Growth Projections-Brier Scores, 2007-2016 20

A.1.1 ADO GDP Average Forecast Errors by Descending Degree of Accuracy on RMSE1 22

A1.2 WEO GDP Average Forecast Errors by Descending Degree of Accuracy on RMSE1 23

A1.3 ADOU GDP Average Forecast Errors by Descending Degree of Accuracy on RMSE1 24

A1.4 WEOU GDP Average Forecast Errors by Descending Degree of Accuracy on RMSE1 25

A1.5 ADO CPI Average Forecast Errors by Descending Degree of Accuracy on RMSE1 26

A1.6 WEO CPI Average Forecast Errors by Descending Degree of Accuracy on RMSE1 27

A1.7 ADOU CPI Average Forecast Errors by Descending Degree of Accuracy on RMSE1 28

A1.8 WEOU CPI Average Forecast Errors by Descending Degree of Accuracy on RMSE1 29

A2.1 ADO GDP Average Forecast Errors by Descending Degree of Accuracy on RMSE1 30

A2.2 WEO GDP Average Forecast Errors by Descending Degree of Accuracy on RMSE1 30

A2.3 ADOU GDP Average Forecast Errors by Descending Degree of Accuracy on RMSE1 30

A2.4 WEOU GDP Average Forecast Errors by Descending Degree of Accuracy on RMSE1 30

A3.1 Gross Domestic Product Growth 31

A3.2 Inflation (Consumer Price Index) 32

A3.3 Asia-43 Average Count Scores by Years-Growth and Inflation 33

A3.4 Asia-11 Average Count Scores by Years-Growth and Inflation 33

A4.1 Asian Development Outlook Optimism 34

A4.2 Asian Development Outlook Update Optimism 35

A4.3 World Economic Outlook Optimism 36

A4.4 World Economic Outlook Update Optimism 37

\section{FIGURES}

1 Asia-43 Gross Domestic Product Growth Forecast Accuracy, 2007-2016 9

$2 \quad$ Asia-43 Inflation Forecast Accuracy, 2007-2016 10

3 Asia-11 GDP Growth Forecast Accuracy, 2007-2016 11

$4 \quad$ Asia-11 Inflation Forecast Accuracy, 2007-2016 12

$5 \quad$ G3 GDP Growth Forecast Accuracy 13

$6 \quad$ G3 GDP Growth Forecast Accuracy 14

A5.1 Asia-43 GDP Growth, Current Year and Year Ahead 38

A5.2 Asia-43 Inflation (CPI) Current Year and Year Ahead 39

A6.1 Asia-43 GDP Growth, Current Year 40

A6.2 Asia-43 GDP Growth, Year Ahead 41

A6.3 Asia-43 Inflation (CPI) Current Year 42

A6.4 Asia-43 Inflation (CPI) Year Ahead 43

A7.1 People's Republic of China 44

A7.2 Hong Kong, China 45 
$\begin{array}{lll}\text { A7.3 Indonesia } & 46\end{array}$

$\begin{array}{lll}\text { A7.4 India } & 47\end{array}$

A7.5 Republic of Korea $\quad 48$

$\begin{array}{lll}\text { A7.6 Malaysia } & 49\end{array}$

$\begin{array}{lll}\text { A7.7 } & \text { Philippines } & 50\end{array}$

A7.8 Singapore $\quad 51$

A7.9 Thailand $\quad 52$

A7.10 Taipei,China

A7.11 Viet Nam $\quad 54$

A8.1 Euro Area $\quad 55$

A8.2 Japan

A8.3 United States

A9 ADO Quarterly Updated GDP Forecast Errors, 2013-2016 Averages 58 



\begin{abstract}
This paper assesses the accuracy of Asian Development Outlook growth and inflation forecasts for 43 Asian economies from 2007 to 2016, against the benchmark of World Economic Outlook projections by the International Monetary Fund. They are found to overlap quite closely, notwithstanding much heterogeneity across countries and years. Forecast accuracy sharpens over time as additional data and evidence become available and get incorporated during quarterly revisions. However, errors widen during crisis years as forecasters struggle to reflect such events in their projections.
\end{abstract}

Keywords: Asian Development Bank, Asian Development Outlook, International Monetary Fund, macroeconomic forecasts, World Economic Outlook

JEL codes: E17, E37 



\section{INTRODUCTION}

Macroeconomic forecasts are not in short supply. Public bodies, both national and international, as well as investment banks and other private institutions, feed a stream of projections anticipating economies' growth performance, price inflation, and other variables for the years ahead. They meet a demand not only from investors, but also from policymakers and institutional bodies eager to sort out authentic information from noise and vested interest.

Absent genuine prescience, and the past being an unreliable guide to the future, forecasts are prone to errors. Forecasting models, however sophisticated, do not work particularly well, or not at all when large shocks occur. Inaccuracy being a given, it does not receive much consideration and hardly ever gets systematically assessed. Continuously sorting through the latest data and leading indicators, and with eyes on the future, forecasters rarely look back on their performance. To fill this gap, an earlier paper focused on Asian Development Bank's (ADB) macroeconomic forecasts from 2008 to 2011 (Ferrarini 2014). It found that the global economic crisis and heightened uncertainty posed a special challenge for forecasters during these years, leading to exceptionally wide errors.

This paper updates and expands earlier analysis in several aspects. The time horizon is broadened from 4 years to 10, with data now spanning the period 2007-2016 and the full set of 40 Asian Development Outlook (ADO) and World Economic Outlook (WEO) reports produced over that time by $A D B$ and the International Monetary Fund (IMF). The data set is expanded to cover 43 ADB developing member countries (DMCs) - up from 33 previously - and also added are the G3 economies, comprising the euro area, Japan, and the United States. The methodology is updated to compute actual growth and inflation rates, as well as optimism bias estimates. Finally, inconsistencies affecting the earlier data have been identified and removed.

\section{FORECAST ERRORS AND MEASURES OF ACCURACY}

The comparative accuracy assessment method in this paper builds on Ferrarini (2014). ADO and WEO forecast errors, $e_{n}$, are defined as difference vectors:

$$
e_{n}=x_{n}-f_{n}
$$

where $x_{n}$ is a vector of observations across countries $c$ and years $t$, and $f_{n}$ is a vector of forecasts. Together, the total number of observations sums over $n$, such that $\Sigma_{n}=\Sigma_{c} \Sigma_{t}$. Forecasts smaller than actual outcomes reflect in positive errors, and projections larger than observed values result in negative values of $e_{n}$.

For an average measure across $n$ forecasts, errors are taken at absolute value $\left|e_{n}\right|$ and averaged. The mean absolute error (MAE) is then computed as

$$
\operatorname{mae}_{n}=\frac{1}{N} \sum_{n}\left|e_{n}\right|
$$

and the root mean squared error (RMSE) as

$$
\mathrm{rmse}_{n}=\sqrt{m s e_{n}}=\sqrt{\frac{1}{N} \sum_{n} e_{n}^{2}} .
$$


The MAE implies equal weights of single items, and its interpretation is straightforward. The mean squared error assigns a relatively higher weight to larger errors, thus punishing forecasts where they occur more frequently. This makes it more sensitive to outliers compared to the MAE. However, in this analysis, the two measures are found to be yielding qualitatively similar results.

To evaluate comparative forecast accuracy, Brier scores are computed similar to those applied for meteorological forecast assessments (Brier 1950). Ex ante, Brier scores are typically derived from probability estimates in relation to actual outcomes. Ex post, when forecast errors from alternative methods or approaches are known, a Brier score can be obtained as an errors' ratio. In the context of this analysis, the Brier score, $b s_{n}$, derives from the ratio of ADO over WEO mean squared errors, which detracts from 1:

$$
b s_{n}=1-\frac{m s e_{n}^{A D O}}{m s e_{n}^{W E O}} \quad-\infty<b s_{n} \leq 1
$$

The Brier score thus defined ranges from negative infinity to 1, with the following interpretation:

$$
\begin{aligned}
& b s_{n}=1 \Rightarrow \text { denotes perfect ADO forecast accuracy, i.e. } m s e_{n}^{A D O}=0, \\
& b s_{n}>0 \Rightarrow \text { ADO outperforms WEO, i.e. } m s e_{n}^{A D O}<m s e_{n}^{W E O}, \\
& b s_{n}<0 \Rightarrow \text { WEO outperforms ADO, i.e. } m s e_{n}^{A D O}>m s e_{n}^{W E O} \text {, and } \\
& b s_{n}=0 \Rightarrow \text { identical accuracy, i.e. } m s e_{n}^{A D O}=m s e_{n}^{W E O} .
\end{aligned}
$$

In addition to gauging relative sizes of errors with the Brier score, a count score is computed, $c s_{n}$, as the relative number of instances in which ADO estimates or forecasts are more accurate than those in WEO. Specifically, the count score is expressed as:

$$
c s_{n}=\frac{1}{N} \sum_{n} s_{n},-1 \leq c s_{n} \leq 1
$$

and ranges from -1 to 1 . It sums across all the individual forecast scores, $s_{n}$, which themselves take values $-1,0$, or 1 according to the comparative size of the ADO and WEO absolute forecast errors:

$$
\begin{aligned}
& s_{n}=1 \text { if }\left|e_{n}\right|^{A D O}<\left|e_{n}\right|^{W E O}, \\
& s_{n}=-1 \text { if }\left|e_{n}\right|^{A D O}>\left|e_{n}\right|^{W E O} \text {, and } \\
& s_{n}=0 \text { if }\left|e_{n}\right|^{A D O}=\left|e_{n}\right|^{W E O} .
\end{aligned}
$$

The count score takes the extreme value -1 if $\left|e_{n}\right|^{A D O}>\left|e_{n}\right|^{W E O} \forall n \in 1 \ldots . . N$. At the opposite extreme, the score will be 1 if ADO errors are smaller than those in WEO for each of the economies 
and years in the sample. More generally, ADO is taken to outperform WEO if $c s_{n}>0$, and the opposite is true when $c s_{n}<0$.

To capture the presence of optimism bias in the forecasts, they are assessed for negative skewness. Also computed are mean errors, $m e_{n}$, across countries and years:

$$
m e_{n}=\frac{1}{N} \sum_{n} e_{n}, \quad-\infty \leq m e_{n} \leq \infty
$$

Optimism bias is present when $m e_{n}<0$, while a prevalence of forecasts lower than actual outcomes-or a more pessimistic stance, so to say-will be reflected in $m e_{n}>0$.

Another measure of optimism bias is the share of incidences in each report of negative forecast errors across countries and years:

$$
c o_{n}=\frac{1}{N-q} \sum_{n} o_{n}, \quad \text { (pessimistic) } 0 \leq c o_{n} \leq 1 \text { (optimistic) }
$$

where:

$$
o_{n}=1 \text { if } e_{n}<0 \text { and } o_{n}=0, q=1 \text { if } e_{n} \geq 0 \text {. }
$$

\section{THE DATA: ASIAN DEVELOPMENT OUTLOOK AND WORLD ECONOMIC OUTLOOK GROWTH AND INFLATION FORECASTS}

The ADO and WEO main reports are released in April each year. Later, in September each year, both institutions issue update reports on their latest data and projections. For short, this paper will refer to the main reports as ADO and WEO, and to their updates as ADOU and WEOU, or simply as updates.

Reflecting its regional area of competence, ADB releases macroeconomic forecasts and analyses for its DMCs, comprising 45 economies in Asia and the Pacific. ADO reports also include an economic outlook on G3 economies - the euro area, Japan, and the United States-which impacts the Asian economies through strong trade and investment links. By contrast, the WEO reports have a nearly global coverage, including ADB's DMCs.

The assessment of comparative forecast accuracy focuses on economies covered in both the ADO and WEO main reports and updates over the decade spanning from 2007 to 2016. 'The data set comprises 43 Asian economies with gross domestic product (GDP) growth and Consumer Price Index (CPI) inflation projections available for each year and from each of the four reports included. For ease of exposition, this data will henceforth be referred to set as Asia-43 and to the growth and inflation projections as "estimates" or "current-year" when they refer to the same year, and to "forecasts" or "year-ahead" when they concern the year to follow. Table 1 lists these economies' three-letter codes and names, and indicates the years for which a full set of data is available. For 33 economies, data availability spans the entire decade of observation. For the remaining economies, especially in the Pacific, some years are missing.

Actually, the analysis also includes reports released in 2006 as a source of year-ahead forecasts for 2007 . This allows the data set to span over an entire decade, from 2007 to 2016. 
Table 1: Economies and Years with Growth and Inflation Data Available in All the Reports

\begin{tabular}{|c|c|c|c|c|c|c|c|c|c|c|c|}
\hline Code & Name & 2007 & 2008 & 2009 & 2010 & 2011 & 2012 & 2013 & 2014 & 2015 & 2016 \\
\hline AFG & Afghanistan & 1 & 1 & 1 & 1 & 1 & 1 & 1 & 1 & 1 & 1 \\
\hline ARM & Armenia & 1 & 1 & 1 & 1 & 1 & 1 & 1 & 1 & 1 & 1 \\
\hline AZE & Azerbaijan & 1 & 1 & 1 & 1 & 1 & 1 & 1 & 1 & 1 & 1 \\
\hline BAN & Bangladesh & 1 & 1 & 1 & 1 & 1 & 1 & 1 & 1 & 1 & 1 \\
\hline BRU & Brunei Darussalam & & & & 1 & 1 & 1 & 1 & 1 & 1 & 1 \\
\hline $\mathrm{BHU}$ & Bhutan & 1 & 1 & 1 & 1 & 1 & 1 & 1 & 1 & 1 & 1 \\
\hline PRC & People's Republic of China ${ }^{a}$ & 1 & 1 & 1 & 1 & 1 & 1 & 1 & 1 & 1 & 1 \\
\hline FIJ & Fiji & 1 & 1 & 1 & 1 & 1 & 1 & 1 & 1 & 1 & 1 \\
\hline FSM & $\begin{array}{l}\text { Federated States of } \\
\text { Micronesia }\end{array}$ & & & & & & & & 1 & 1 & 1 \\
\hline GEO & Georgia & & & & 1 & 1 & 1 & 1 & 1 & 1 & 1 \\
\hline HKG & Hong Kong, China ${ }^{a}$ & 1 & 1 & 1 & 1 & 1 & 1 & 1 & 1 & 1 & 1 \\
\hline INO & Indonesia $^{\mathrm{a}}$ & 1 & 1 & 1 & 1 & 1 & 1 & 1 & 1 & 1 & 1 \\
\hline IND & India $^{a}$ & 1 & 1 & 1 & 1 & 1 & 1 & 1 & 1 & 1 & 1 \\
\hline KAZ & Kazakhstan & 1 & 1 & 1 & 1 & 1 & 1 & 1 & 1 & 1 & 1 \\
\hline KGZ & Kyrgyz Republic & 1 & 1 & 1 & 1 & 1 & 1 & 1 & 1 & 1 & 1 \\
\hline CAM & Cambodia & 1 & 1 & 1 & 1 & 1 & 1 & 1 & 1 & 1 & 1 \\
\hline KIR & Kiribati & & & 1 & 1 & 1 & 1 & 1 & 1 & 1 & 1 \\
\hline KOR & Republic of Korea ${ }^{a}$ & 1 & 1 & 1 & 1 & 1 & 1 & 1 & 1 & 1 & 1 \\
\hline LAO & $\begin{array}{l}\text { Lao People's Democratic } \\
\text { Republic }\end{array}$ & 1 & 1 & 1 & 1 & 1 & 1 & 1 & 1 & 1 & 1 \\
\hline SRI & Sri Lanka & 1 & 1 & 1 & 1 & 1 & 1 & 1 & 1 & 1 & 1 \\
\hline MLD & Maldives & 1 & 1 & 1 & 1 & 1 & 1 & 1 & 1 & 1 & 1 \\
\hline RMI & Marshall Islands & & & & & & & & 1 & 1 & 1 \\
\hline MYA & Myanmar & & & & & 1 & 1 & 1 & 1 & 1 & 1 \\
\hline $\begin{array}{l}\mathrm{MO} \\
\mathrm{N}\end{array}$ & Mongolia & 1 & 1 & 1 & 1 & 1 & 1 & 1 & 1 & 1 & 1 \\
\hline MAL & Malaysia $^{a}$ & 1 & 1 & 1 & 1 & 1 & 1 & 1 & 1 & 1 & 1 \\
\hline NEP & Nepal & 1 & 1 & 1 & 1 & 1 & 1 & 1 & 1 & 1 & 1 \\
\hline PAK & Pakistan & 1 & 1 & 1 & 1 & 1 & 1 & 1 & 1 & 1 & 1 \\
\hline $\mathrm{PHI}$ & Philippines $^{\mathrm{a}}$ & 1 & 1 & 1 & 1 & 1 & 1 & 1 & 1 & 1 & 1 \\
\hline PAL & Palau & & & & & & & & & 1 & 1 \\
\hline PNG & Papua New Guinea & 1 & 1 & 1 & 1 & 1 & 1 & 1 & 1 & 1 & 1 \\
\hline SIN & Singapore $^{a}$ & 1 & 1 & 1 & 1 & 1 & 1 & 1 & 1 & 1 & 1 \\
\hline $\mathrm{SOL}$ & Solomon Islands & 1 & 1 & 1 & 1 & 1 & 1 & 1 & 1 & 1 & 1 \\
\hline THA & Thailand $^{a}$ & 1 & 1 & 1 & 1 & 1 & 1 & 1 & 1 & 1 & 1 \\
\hline TAJ & Tajikistan & 1 & 1 & 1 & 1 & 1 & 1 & 1 & 1 & 1 & 1 \\
\hline TKM & Turkmenistan & & 1 & 1 & 1 & 1 & 1 & 1 & 1 & 1 & 1 \\
\hline TIM & Timor-Leste & & 1 & 1 & 1 & 1 & 1 & 1 & 1 & 1 & 1 \\
\hline TON & Tonga & 1 & 1 & 1 & 1 & 1 & 1 & 1 & 1 & 1 & 1 \\
\hline TUV & Tuvalu & & & & & & 1 & 1 & 1 & 1 & 1 \\
\hline TAP & Taipei,China $^{a}$ & 1 & 1 & 1 & 1 & 1 & 1 & 1 & 1 & 1 & 1 \\
\hline UZB & Uzbekistan & 1 & 1 & 1 & 1 & 1 & 1 & 1 & 1 & 1 & 1 \\
\hline VIE & Viet $\mathrm{Nam}^{\mathrm{a}}$ & 1 & 1 & 1 & 1 & 1 & 1 & 1 & 1 & 1 & 1 \\
\hline VAN & Vanuatu & 1 & 1 & 1 & 1 & 1 & 1 & 1 & 1 & 1 & 1 \\
\hline SAM & Samoa & & 1 & 1 & 1 & 1 & 1 & 1 & 1 & 1 & 1 \\
\hline
\end{tabular}

"Included in the Asia-11 subgroup of economies.

Source: Author. 
Table 2: 2010 Growth and Inflation Data Sourcing Example

\begin{tabular}{lccc}
\hline & $\begin{array}{c}2010 \text { Forecasts } \\
\text { (year ahead) }\end{array}$ & $\begin{array}{c}\text { 2010 Estimates } \\
\text { (current year) }\end{array}$ & $\begin{array}{c}2010 \text { Observations } \\
\text { (previous year) }\end{array}$ \\
\hline ADO/WEO & 2009 & 2010 & 2011 \\
ADOU/WEOU & 2009 & 2010 & 2011 \\
Computed: & as is & as is & ADOU/WEOU average \\
\hline
\end{tabular}

$\mathrm{ADO}=$ Asian Development Outlook, $\mathrm{ADOU}=$ Asian Development Outlook Update, $\mathrm{WEO}=$ World Economic Outlook, WEOU = World Economic Outlook Update.

Source: Author.

Table 2 illustrates how the data was sourced and sorted. For example, in relation to 2010 growth and inflation, the ADO and WEO reports released in April 2009 featured the earliest available set of forecasts, which later got revised in the September 2009 ADOU and WEOU reports, and then again in the April 2010 main and the September 2010 update reports as current-year estimates. Altogether, there are four projections in relation to 2010 variables. These are followed by a first, preliminary, gauge of 2010 growth and inflation, available in the 2011 spring reports, and later revised measures in the fall update reports, on the basis of more consolidated evidence and data.

Occasionally, ADOU and WEOU growth and inflation consolidated statistics may differ slightly. For a common reference of actual data against which to measure the distance of projections, average ADOU and WEOU figures are computed from the reports released in the year immediately following the projections. This departs from Ferrarini (2014), which used the latest GDP and inflation series available at the time of writing. However, if official estimates of past GDP and inflation get revised substantially over time, using their latest updates unduly affects accuracy measures because of factors unrelated to the evidence available at the time when forecasts were made.

Besides the Asia-43 group of economies, average forecast errors and accuracy scores are computed across a smaller sample of 11 key economies in the region: Hong Kong, China; India; Indonesia; Malaysia; the People's Republic of China (PRC); the Philippines; the Republic of Korea; Singapore; Taipei,China; Thailand; and Viet Nam. The Asia-11 aggregate allows for a more focused set of measures, without the clutter and volatility associated with the highly heterogenous group of Asia43 economies, which also includes the Pacific island economies. Moreover, each of the 11 economies has a full set of data available for the entire period of analysis, so that the Asia-11 sample can be suitably split into two equally spaced 5 -year periods. This allows for investigation of any substantial difference in forecast performance in the two periods, one spanning from 2007 to 2011 and including the crisis years, and another from 2012 to 2016, comprising much of the postcrisis recovery.

Besides the data extracted from the regular ADO and WEO main and update reports, another data set is created to include a subsample of ADO data only, to which are added growth and inflation projections from the ADO Supplements (ADOS). Starting 2012, these forecasts have been released in July and December every year, to integrate ADO and ADOU projections with quarterly updates. This will allow control for the absorption of information that becomes progressively available throughout the year, and its effects in terms of sharper forecasts as time closes in. Four projections made 1 year ahead plus four updates in the current year bring to eight the total number of projections corresponding to each growth and inflation data point in this data set. 
An additional data set includes the euro area, Japan, and the United States. ADO features GDP growth and inflation forecasts for the G3 economies as a group, and also growth projections for the euro area, Japan, and the United States individually. However, disaggregate inflation forecasts are not available, and the analysis is limited to growth projections.

\section{ASIAN DEVELOPMENT OUTLOOK COMPARATIVE FORECAST ACCURACY}

The core findings from comparative measures of forecast accuracy computed across the Asia-43, Asia-11, and G3 data sets are organized as charts and tables by economy groupings and variables. Figure 1 shows average GDP growth forecast errors and scores across Asia-43 economies and years. Figure 2 shows the same for Asia-43 inflation. Figure 3 and Figure 4 feature similar sets of charts on Asia-11, and Figure 5 and Figure 6 on the $\mathrm{G} 3$ economies.

The more finely disaggregated tabulations and charts are relegated to a number of appendixes. Figure A5.1 and Figure A5.2 show yearly averages of errors and scores across the whole of Asia- 43. Figures A6.1-A6.4 show period averages for the 43 economies individually. At the finest level of detail, Appendix 7 contains yearly bar charts for selected economies.

For an overview of results, Table 3 summarizes the core statistics by country aggregates and time periods. For each of the four reports, shown are mean average errors and RMSEs, in relation to current-year estimates (MAEO and RMSE0) and year-ahead forecasts (MAE1 and RMSE1). Also shown are actual growth and inflation averages (Avg) and the coefficient of variation (CoV), to account for the varying degrees of volatility across the aggregates.

\section{A. Asia-43-Gross Domestic Product Growth Forecasts}

Both forecasters' growth projections contain large errors on average. For current-year estimates, e.g., 2010 growth projected in 2010, the average error is nearly one-third of average growth (Table 3 and Figure 1). For year-ahead forecasts, e.g., 2010 growth projected in April 2009, it is nearly one-half. For example, an average country growing by $5 \%$ in any given year would have been expected to expand by as little as $2.6 \%$ or nearly $7.6 \%$ instead. Aggregate RMSEs of year-ahead forecasts are even larger, exceeding 3.2 percentage points on average, because of the heavier weights assigned to larger errors.

On average across Asia-43, ADO forecast errors are smaller than those of WEO. This is also the case for ADOU-compared to WEOU-but distances are less pronounced. Brier scores are positive as a result. At less than 0.1, they are negligible for all but ADO versus WEO current-year estimates, which measures 0.16 (Figure 1). ${ }^{2}$ This suggests that ADO and ADOU come out just ahead of WEO and WEOU, but only marginally so.

2 The Brier scale has a maximum of 1, which would be reached if ADO forecast errors were either zero or infinitely smaller than WEO errors across all the economies and years. 
Table 3: Asia-43 and Asia-11 Average Forecast Errors by Report, Across Countries, and Years (Percentage points)

\begin{tabular}{|c|c|c|c|c|c|c|}
\hline \multirow[b]{2}{*}{ Sample } & \multirow[b]{2}{*}{ Variable } & \multirow[b]{2}{*}{ Report } & \multicolumn{2}{|c|}{ Current Year } & \multicolumn{2}{|c|}{ Year Ahead } \\
\hline & & & MAEO & RMSEO & MAE1 & RMSE1 \\
\hline & GDP & ADO & 1.52 & 2.29 & 2.29 & 3.38 \\
\hline & Avg: 4.97 & WEO & 1.65 & 2.50 & 2.39 & 3.51 \\
\hline & CoV: 0.77 & ADOU & 1.08 & 1.62 & 2.14 & 3.21 \\
\hline & & WEOU & 1.09 & 1.69 & 2.14 & 3.24 \\
\hline \multirow{9}{*}{$\begin{array}{l}\text { Asia-43 } \\
\text { 2007-2016 }\end{array}$} & & & & & & \\
\hline & CPI & ADO & 2.11 & 3.39 & 2.97 & 4.44 \\
\hline & Avg: 5.44 & WEO & 1.82 & 2.87 & 2.92 & 4.45 \\
\hline & CoV: 0.90 & ADOU & 1.15 & 1.90 & 2.90 & 4.47 \\
\hline & & WEOU & 0.96 & 1.49 & 2.86 & 4.34 \\
\hline & GDP & ADO & 1.25 & 1.79 & 2.03 & 2.88 \\
\hline & Avg: 4.85 & WEO & 1.31 & 1.98 & 2.21 & 3.23 \\
\hline & CoV: 0.62 & ADOU & 0.72 & 1.12 & 1.87 & 2.72 \\
\hline & & WEOU & 0.63 & 0.94 & 1.72 & 2.49 \\
\hline \multirow{9}{*}{$\begin{array}{l}\text { Asia-11 } \\
\text { 2007-2016 }\end{array}$} & & & & & & \\
\hline & CPI & ADO & 1.06 & 1.54 & 1.99 & 2.93 \\
\hline & Avg: 3.85 & WEO & 1.05 & 1.54 & 1.92 & 2.85 \\
\hline & CoV: 0.91 & ADOU & 0.43 & 0.78 & 2.00 & 3.07 \\
\hline & & WEOU & 0.47 & 0.72 & 1.90 & 2.82 \\
\hline & GDP & ADO & 1.66 & 2.28 & 2.69 & 3.69 \\
\hline & Avg: 5.26 & WEO & 1.82 & 2.57 & 3.03 & 4.22 \\
\hline & CoV: 0.70 & ADOU & 1.04 & 1.47 & 2.54 & 3.51 \\
\hline & & WEOU & 0.88 & 1.20 & 2.30 & 3.16 \\
\hline \multirow{9}{*}{$\begin{array}{l}\text { Asia-11 } \\
\text { 2007-2011 }\end{array}$} & & & & & & \\
\hline & $\mathrm{CPI}$ & $A D O$ & 1.39 & 1.99 & 2.50 & 3.70 \\
\hline & Avg: 4.78 & WEO & 1.23 & 1.85 & 2.42 & 3.60 \\
\hline & CoV: 0.88 & ADOU & 0.55 & 1.03 & 2.70 & 4.05 \\
\hline & & WEOU & 0.48 & 0.68 & 2.44 & 3.63 \\
\hline & GDP & ADO & 0.85 & 1.10 & 1.37 & 1.73 \\
\hline & Avg: 4.45 & WEO & 0.80 & 1.12 & 1.39 & 1.75 \\
\hline & CoV: 0.47 & ADOU & 0.40 & 0.58 & 1.19 & 1.58 \\
\hline & & WEOU & 0.38 & 0.57 & 1.14 & 1.56 \\
\hline \multirow{5}{*}{$\begin{array}{l}\text { Asia-11 } \\
\text { 2012-2016 }\end{array}$} & & & & & & \\
\hline & $\mathrm{CPI}$ & $A D O$ & 0.74 & 0.90 & 1.48 & 1.87 \\
\hline & Avg: 2.92 & WEO & 0.87 & 1.13 & 1.43 & 1.82 \\
\hline & CoV: 0.78 & ADOU & 0.31 & 0.42 & 1.30 & 1.58 \\
\hline & & WEOU & 0.46 & 0.76 & 1.37 & 1.66 \\
\hline
\end{tabular}

$\mathrm{ADO}=$ Asian Development Outlook, $\mathrm{ADOU}=$ Asian Development Outlook Update, $\mathrm{CPI}=$ Consumer Price Index, $\mathrm{GDP}=$ gross domestic product, $\mathrm{MAE}=$ mean absolute error, $\mathrm{RMSE}=$ root mean squared error, $\mathrm{WEO}=$ World Economic Outlook, WEOU = World Economic Outlook Update.

Notes: Averages (Avg) and coefficients of variation (CoV) are computed across observed growth and inflation rates. Asia-43 refers to 45 developing member countries of ADB; Cook Islands and Nauru are excluded due to data issues. Asia-11 refers to Hong Kong, China; India; Indonesia; Malaysia; the People's Republic of China; the Philippines; the Republic of Korea; Singapore; Thailand; Taipei,China; and Viet Nam.

Source: Author's calculations. 
Table 4: G3 Average Forecast Errors by Report and Periods

(Percentage points)

\begin{tabular}{lllcccc}
\hline & & & \multicolumn{2}{c}{ Current Year } & \multicolumn{2}{c}{ Year Ahead } \\
\cline { 4 - 7 } Period & Variable & Report & MAEO & RMSE0 & MAE1 & RMSE1 \\
\hline \multirow{3}{*}{$2007-2016$} & GDP & ADO & 0.76 & 1.03 & 1.51 & 2.26 \\
& Avg: 0.88 & WEO & 0.60 & 0.85 & 1.51 & 2.22 \\
& CoV: 2.31 & ADOU & 0.41 & 0.59 & 1.43 & 2.06 \\
& & WEOU & 0.36 & 0.52 & 1.20 & 1.76 \\
\hline \multirow{3}{*}{$2007-2011$} & GDP & ADO & 1.07 & 1.34 & 2.34 & 3.05 \\
& Avg: 0.43 & WEO & 0.75 & 1.07 & 2.39 & 2.99 \\
& CoV: 6.10 & ADOU & 0.49 & 0.70 & 2.17 & 2.78 \\
& & WEOU & 0.43 & 0.62 & 1.84 & 2.37 \\
\hline \multirow{2}{*}{$2012-2016$} & GDP & ADO & 0.45 & 0.57 & 0.68 & 0.93 \\
& Avg: 1.33 & WEO & 0.44 & 0.57 & 0.64 & 0.94 \\
& CoV: 0.81 & ADOU & 0.32 & 0.44 & 0.68 & 0.87 \\
& & WEOU & 0.29 & 0.40 & 0.55 & 0.75 \\
\hline
\end{tabular}

$\mathrm{ADO}=$ Asian Development Outlook, $\mathrm{ADOU}=$ Asian Development Outlook Update, $\mathrm{GDP}=$ gross domestic product, $\mathrm{MEA}=$ mean absolute error, $\mathrm{RMSE}=$ root mean squared error, WEO = World Economic Outlook, WEOU = World Economic Outlook Update.

Note: Averages (Avg) and coefficients of variation (CoV) are computed across observed growth and inflation rates.

Source: Author's calculations.

ADOU and WEOU projections, released in fall each year, are far more accurate than those of the main reports released earlier, in spring, because both forecasters can access evidence that is more up-to-date and reliable compared to that available half a year earlier. Over a period of revisions spanning 2 years - such as from year-ahead forecasts in ADO 2009, to ADOU 2009, on to currentyear estimates in ADO 2010 and then to ADOU 2010-forecast errors can indeed be seen getting smaller and smaller (Figure 1). This is confirmed by the analysis of quarterly updates of the Asia-11 aggregate, discussed below.

Count scores, shown in the third row of Figure 1, confirm Brier scores, by and large. Again, scores are small and far from reaching the upper boundary of 1 , which would entail consistently more accurate ADO forecasts across each of the 43 economies and 10 years of data. Instead, ADO main reports are just slightly ahead of WEO in terms of current and year-ahead forecasts, and ADOU has a small lead in relation to current-year estimates. Not so for WEOU, which beats ADOU on year-ahead forecasts. Anyway, the differences observed are small, suggesting a fairly close match across the reports.

Appendix 5, Figure A5.1, breaks down GDP forecast errors and scores by years. Charts in the upper half show that errors were larger during the first few years, especially in 2009 and 2010, when the global financial crisis hit Asia. Again, ADO and WEO errors appear to be similar in size, with some exceptions, such as the 2010 year-ahead forecasts, when WEO was farther off target. Any such differences translate into positive or negative values of the Brier and count scores, shown in the bottom charts of Figure A5.1. Even if the balance is slightly in favor of ADO and ADOU, particularly with regard to current-year estimates, many years have Brier and count scores in favor of the WEO and WEOU. 
Figure 1: Asia-43 Gross Domestic Product Growth Forecast Accuracy, 2007-2016
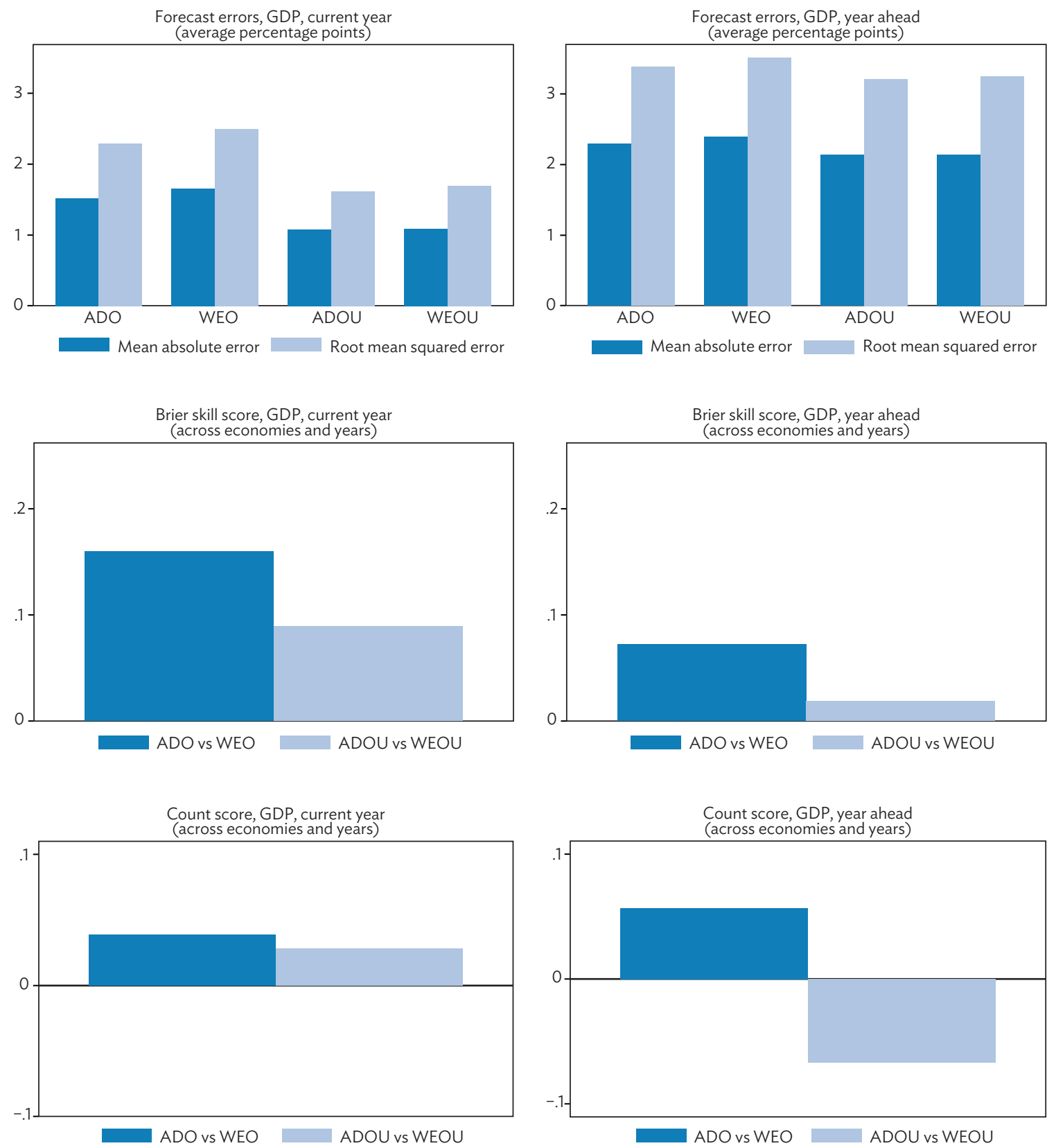

$\mathrm{ADO}=$ Asian Development Outlook, $\mathrm{ADOU}=$ Asian Development Outlook Update, $\mathrm{GDP}=$ gross domestic product, $\mathrm{vs}=$ versus WEO $=$ World Economic Outlook, WEOU = World Economic Outlook Update.

Note: Asia-43 refers to 45 developing member countries of ADB; Cook Islands and Nauru are excluded due to data issues.

Source: Author's calculations. 


\section{Figure 2: Asia-43 Inflation Forecast Accuracy, 2007-2016}
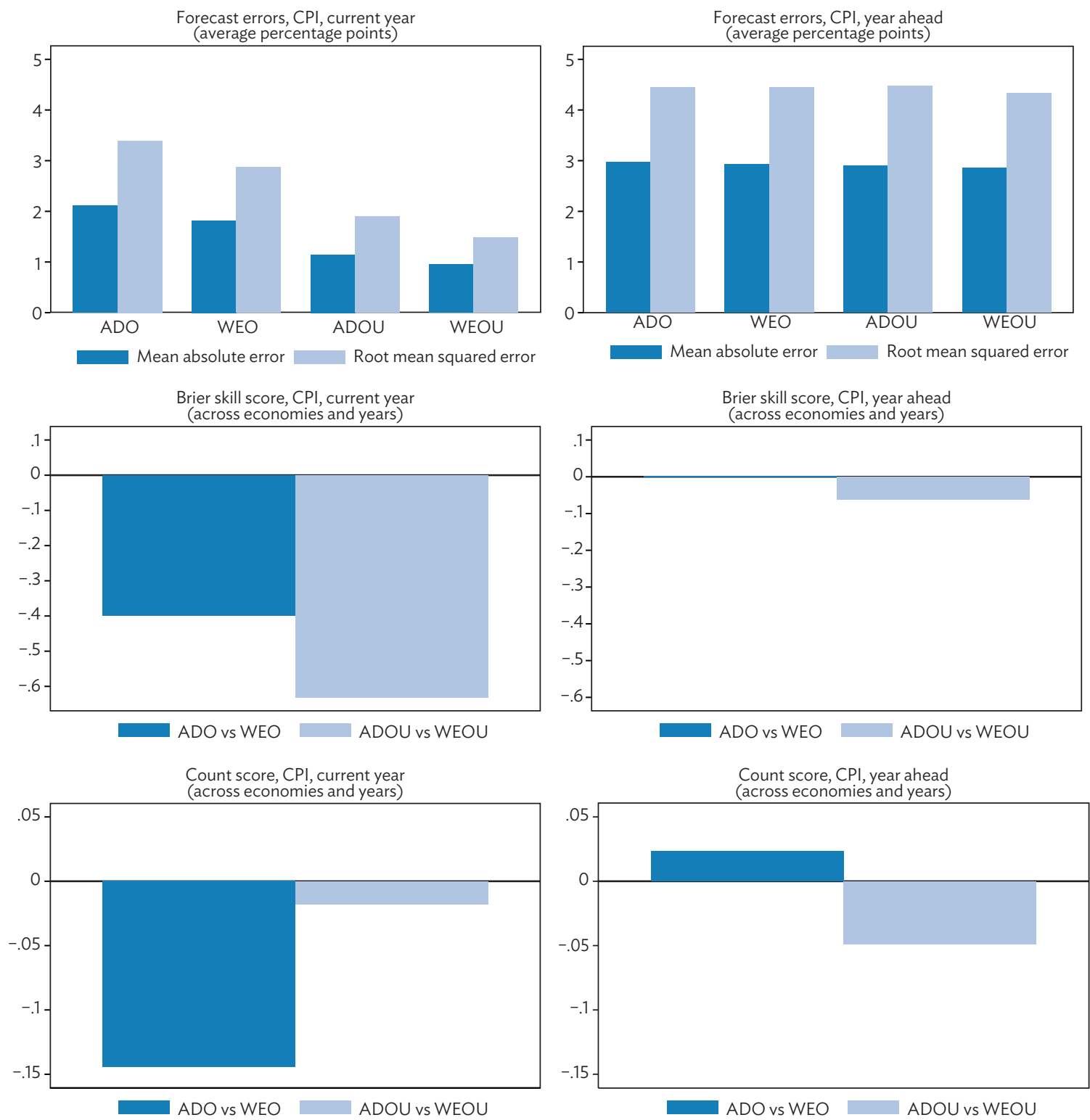

$\mathrm{ADO}=$ Asian Development Outlook, $\mathrm{ADOU}=\mathrm{Asian}$ Development Outlook Update, $\mathrm{CPI}=$ Consumer Price Index, vs $=$ versus, $\mathrm{WEO}=$ World Economic Outlook, WEOU = World Economic Outlook Update.

Note: Asia-43 refers to 45 developing member countries of ADB; Cook Islands and Nauru are excluded due to data issues.

Source: Author's calculations. 
Figure 3: Asia-11 Gross Domestic Product Growth Forecast Accuracy, 2007-2016
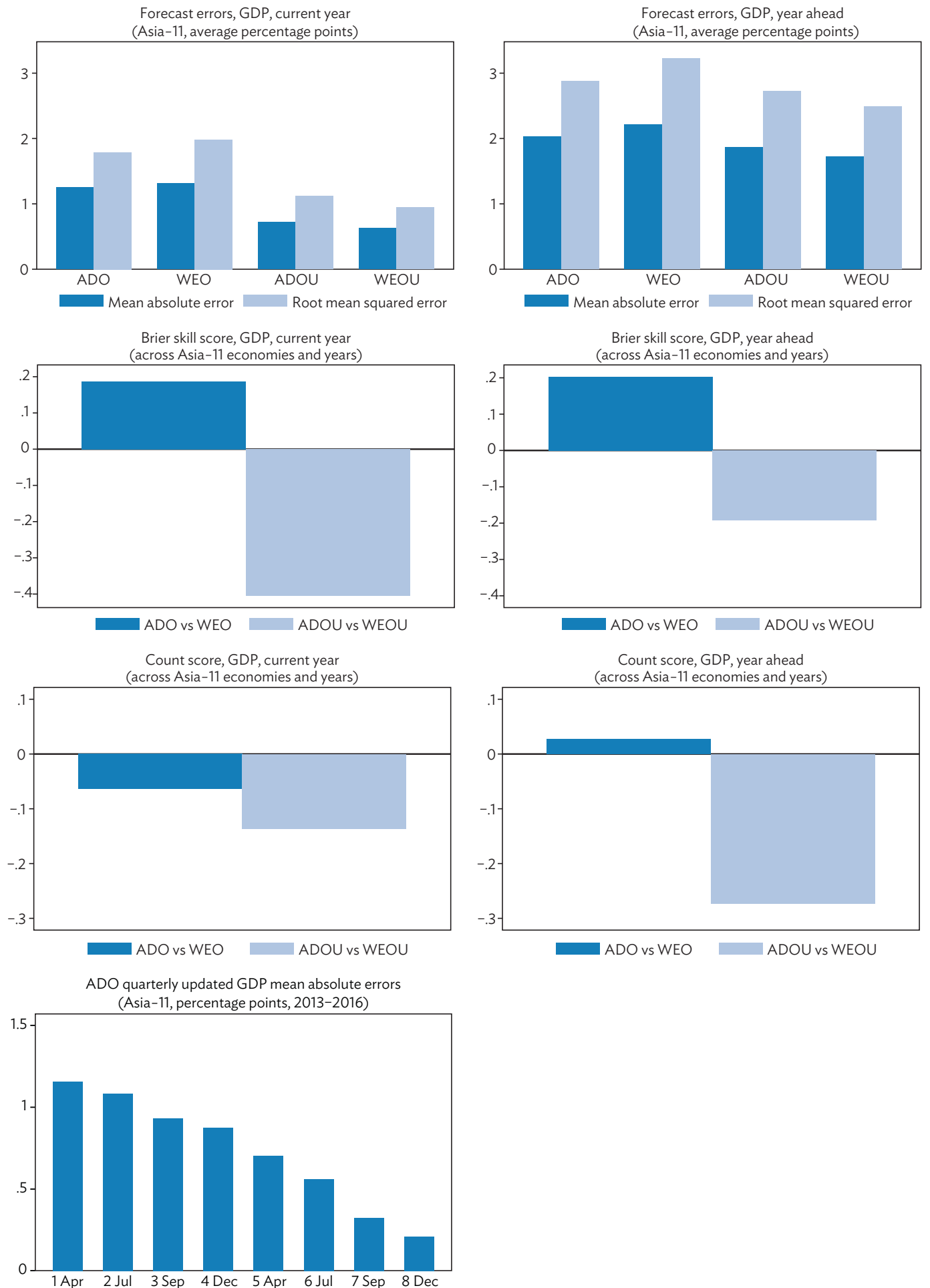

$\mathrm{ADO}=$ Asian Development Outlook, $\mathrm{ADOU}=$ Asian Development Outlook Update, $\mathrm{GDP}=$ gross domestic product, vs $=$ versus WEO = World Economic Outlook, WEOU = World Economic Outlook Update.

Note: Asia-11 refers to Hong Kong, China; India; Indonesia; Malaysia; the People's Republic of China; the Philippines; the Republic of Korea; Singapore; Thailand; Taipei,China; and Viet Nam.

Source: Author's calculations. 


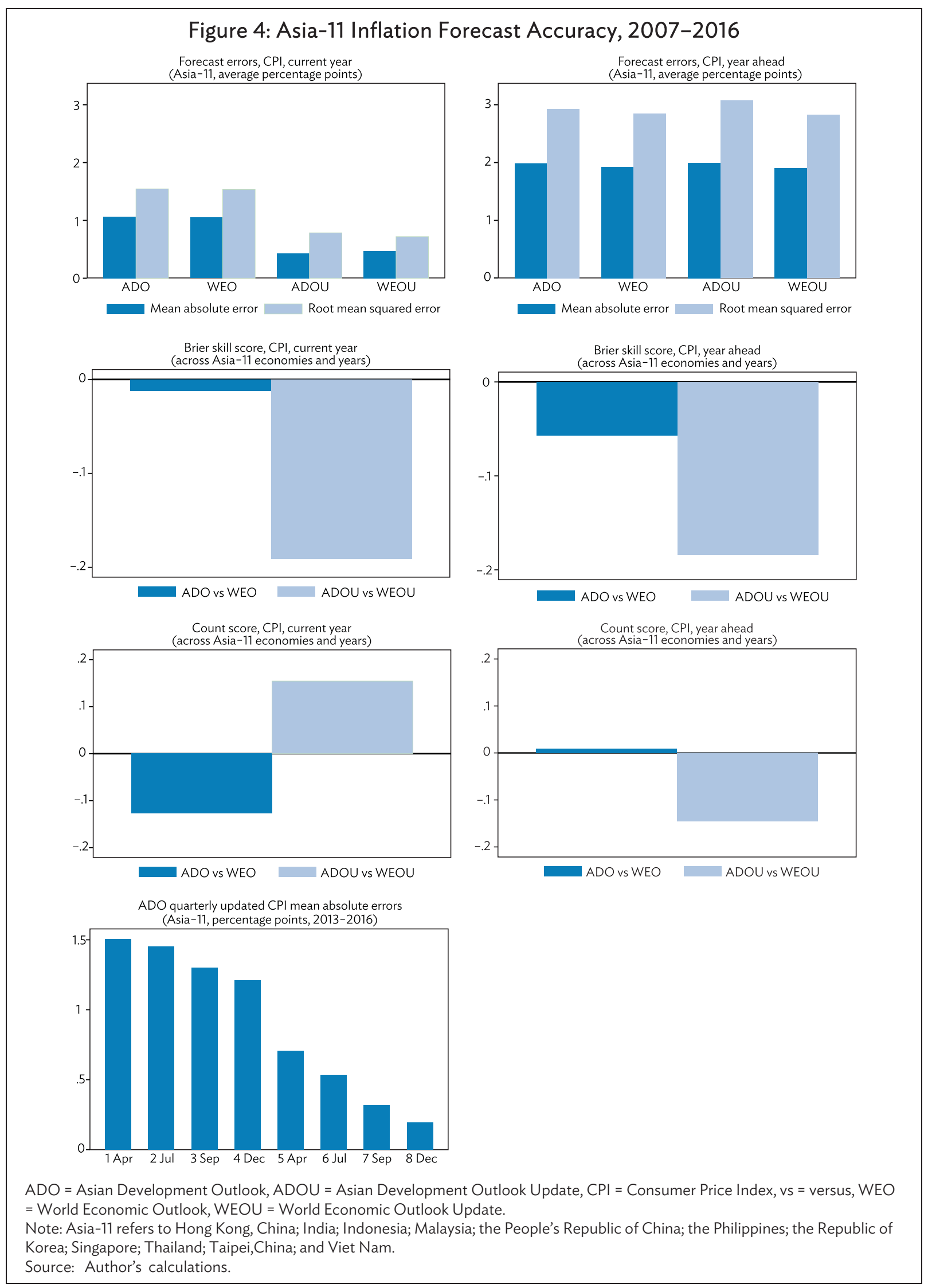




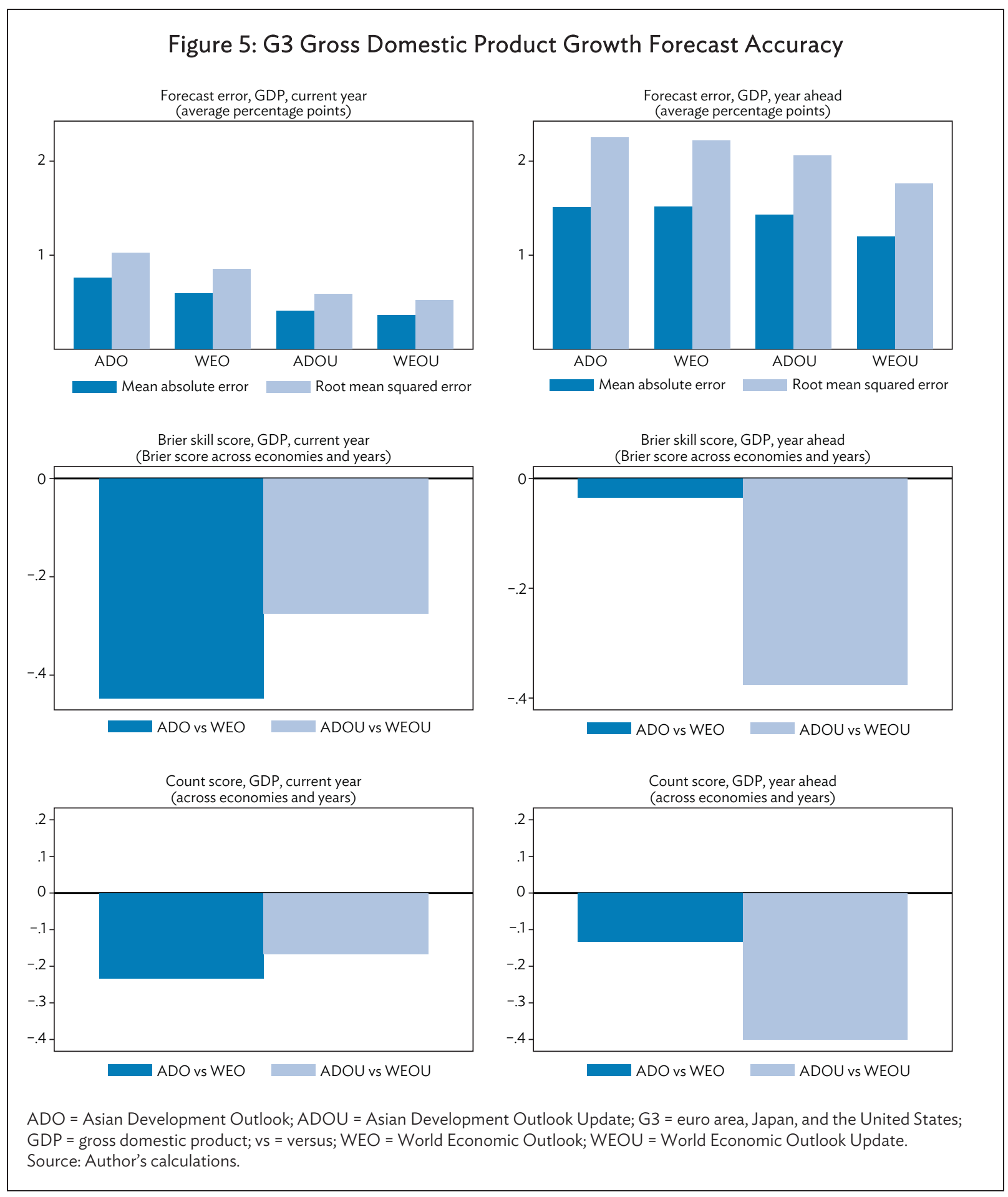




\section{Figure 6: G3 Gross Domestic Product Growth Forecast Accuracy}
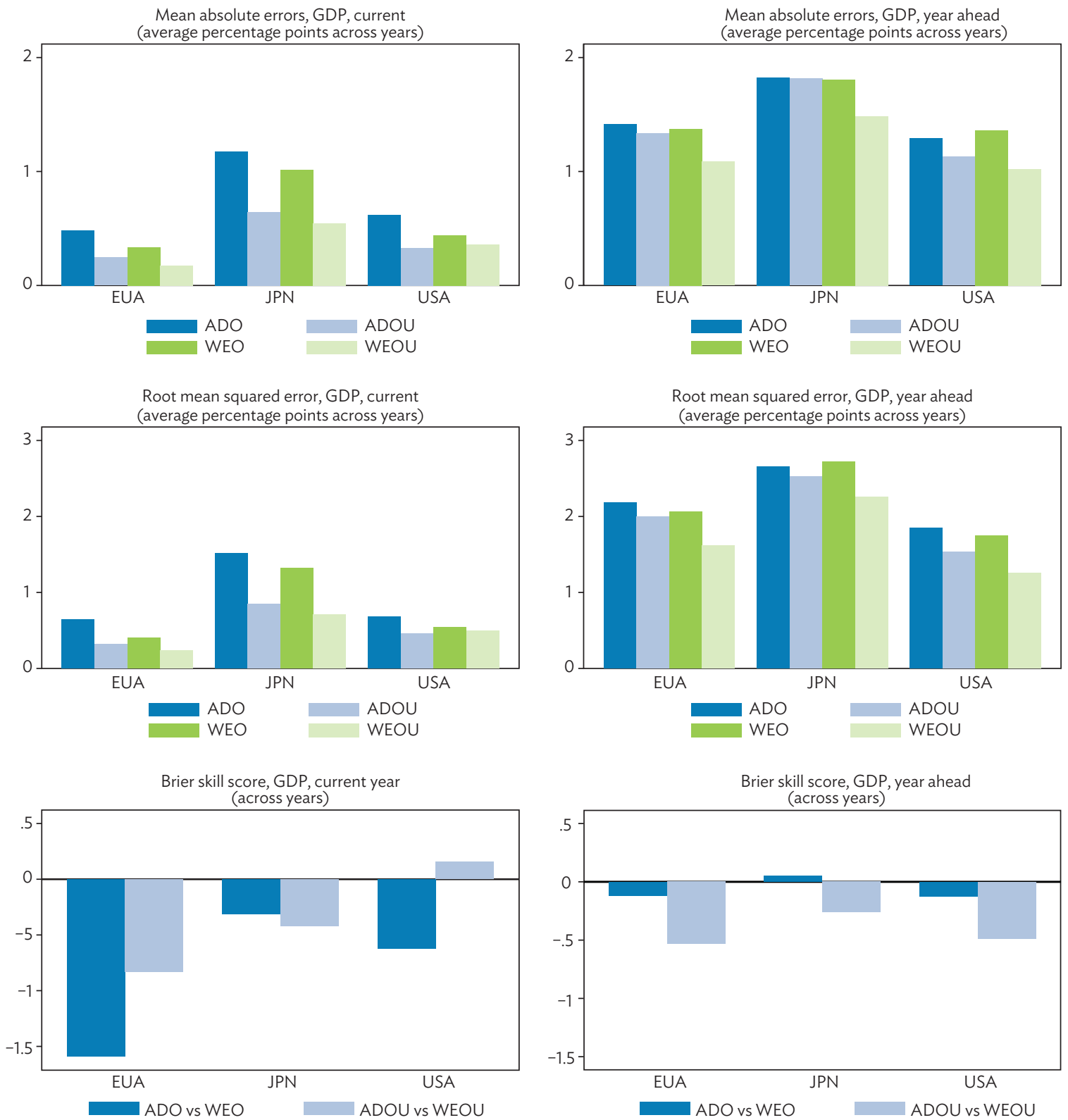

ADO = Asian Development Outlook; ADOU = Asian Development Outlook Update; EUA = euro area; G3 = euro area, Japan, and the United States; GDP = gross domestic product; JPN = Japan; USA = United States of America; vs = versus; WEO = World Economic Outlook; WEOU = World Economic Outlook Update.

Source: Author's calculations. 
Much of the variation within the Asia-43 aggregate comes from the small economies and those depending on oil exports, which tend to be associated with large forecast errors. For current-year GDP growth projections, this is shown in Appendix 6, Figure A6.1, which breaks down RMSEs and Brier scores by country averages across years. For example, ADO growth projections are least accurate for Armenia, Afghanistan, and the Kyrgyz Republic. Conversely, projections are most precise for countries like Bangladesh, Indonesia, or Viet Nam.

Economies' Brier scores are largest where the size of average errors differs the most among the reports. For example, the right-hand chart in Figure A6.2 indicates that ADO and ADOU score highest for the Marshall Islands, Brunei Darussalam, and Kiribati. They are lowest for the Federated States of Micronesia, Bangladesh, and Tuvalu. For some economies, such as the PRC and Indonesia, ADO's advantage over WEO got lost entirely by the time the update reports were released, when WEOU managed to come up with more precise growth projections compared to ADOU. The reverse is true for some other economies, such as Mongolia. Some of these patterns are confirmed by count scores for individual economies, shown in Appendix 3, Table A3.1, and summarized in Tables A3.2-A3.4.

For completeness of exposition, Appendix 1, Tables A1.1 to A1.4, provide detailed tabulations of individual economies' errors for each of the four reports, ranked by descending RMSEs. Also shown is the coefficient of variation, which tends to be higher for economies associated with larger forecast errors and rank lower in the tables. There are exceptions, especially the Pacific economies with only few years of observation available, which affects the CoV measure.

In sum, the average magnitudes of errors in the ADB and IMF growth forecasts in the Asia-43 sample are similar. Although ADO and ADOU projections score slightly higher on average, results are very mixed indeed, and they vary across individual years and economies. For all the reports, accuracy tends to improve over time, as more information becomes available and projections converge toward actual growth rates, causing errors to shrink.

\section{B. Asia-43-Consumer Price Index Inflation Forecasts}

Inflation tends to be forecast less accurately than growth (Figure 2). Projections 1 year ahead entail mean average errors of nearly 3 percentage points (Table 3). Moreover, average accuracy improves only slightly from the main reports to the release of updates. WEO and WEOU current-year inflation estimates are more accurate than those in ADO and ADOU, and Brier scores are negative as a result. Not so in relation to year-ahead inflation forecasts, where scores close to zero suggest a more even match, and differences are rather negligible. Count scores corroborate these findings.

Unsurprisingly, inflation errors are largest in 2008-2010, during the global economic crisis (Figure A5.2). Brier and count scores both suggest that WEO and WEOU projections were significantly more accurate for 2008, 2009, 2012, and 2014 estimates, as well as for 2007 forecasts. The evidence is mixed for the other years, especially in relation to year-ahead inflation forecasts, where ADO and ADOU did better in some years, such as in 2010.

Breaking down results by economies, Figure A6.3 and Figure A6.4 identify smaller and more vulnerable economies as the main sources of error, driving up averages. ADO's largest RMSE is recorded for Afghanistan, in excess of 8 percentage points in relation to current-year inflation, and 10 percentage points with regard to inflation forecasts. Yearly data reveal that this reflects extremely large errors in both 2008 and 2009. 
Brier scores tend to favor WEO and WEOU, especially in relation to current-year estimates. Scores are largest where the difference in mean square errors among the reports is most pronounced, such as for Turkmenistan (Figure A6.3) and Tuvalu (Figure A6.4). ${ }^{3}$

In sum, WEO and WEOU inflation projections tend to be more accurate than those in ADO and ADOU, especially in relation to current-year estimates. Differences in year-ahead projections are too small to be conclusive, but they too point to somewhat higher accuracy of the WEOU reports. Similarly to growth, accuracy measures of inflation projections reveal a great deal of heterogeneity across the Asia-43 aggregate and years considered. ${ }^{4}$

\section{Asia-43-Are Growth Forecasts Overly Optimistic?}

For each of the Asia-43 economies, size and count measures of optimism are computed according to the method described in section II. ${ }^{5}$ Data from 2007 to 2010 is excluded because the economic crisis took forecasters by surprise, so much as to cause a break in the data that would overshadow and invalidate the optimism measure. What remains are 6 years of GDP projections, from 2011 to 2016.

Table 5 shows skewness, as well as averages of the size and count measures in relation to each of the four reports. On account of current-year estimates, ADO has the strongest optimistic bias among these reports, with a size measure equal to -0.24 . WEO is less optimistic, at -0.11 , and both the update reports are fairly balanced, at 0.04, without any significant bias. Far more significant are the readings with regard to year-ahead forecasts, where uncertainty is higher and optimism comes to play. Indeed, large negative average errors in all the reports point to a somewhat overoptimistic bias throughout, especially in ADO (-0.63). Count measures in excess of 0.5 and negative skewness across year-ahead forecasts confirm the presence of an optimism bias.

Table 5: Asia-43 Gross Domestic Product Forecast Optimism, 2011-2016

\begin{tabular}{lcccccc}
\hline & \multicolumn{3}{c}{ Current Year } & \multicolumn{3}{c}{ Year Ahead } \\
\hline Report & Skew & Size & Count & Skew & Size & Count \\
\hline ADO & 0.11 & -0.24 & 0.52 & -0.17 & -0.63 & 0.59 \\
ADOU & 0.36 & 0.04 & 0.44 & -0.06 & -0.49 & 0.59 \\
WEO & -0.31 & -0.11 & 0.51 & -0.29 & -0.43 & 0.59 \\
WEOU & 0.49 & 0.04 & 0.50 & -0.30 & -0.46 & 0.59 \\
\hline
\end{tabular}

$\mathrm{ADO}=$ Asian Development Outlook, $\mathrm{ADOU}=$ Asian Development Outlook Update, WEO = World Economic Outlook, WEOU = World Economic Outlook Update.

Note: Asia-43 refers to 45 developing member countries of ADB; Cook Islands and Nauru are excluded due to data issues.

Source: Author's calculations.

3 However, even for these economies, an apparently large difference is likely caused by an outlier year, rather than a significant qualitative difference of forecast quality over the entire period of observation. For example, ADOU 2009 failed to reverse the ADO current-year inflation estimates for Turkmenistan, which turned out experiencing deflation that year. By contrast, WEOU was able to anticipate that turnaround and adjust its inflation estimates accordingly, thereby ending up committing a significantly smaller error compared to ADOU. Besides this specific lapse, and another in relation to 2010 year-ahead forecasts, the inflation projections for Turkmenistan in the two reports are quite similar.

4 Tables A1.5 to A1.8 in Appendix 1 provide detailed tabulations of CPI forecast errors for each of the four reports, ranked by descending RMSEs.

5 It will be recalled from the definition in section II, that a negative size measure is taken to indicate an overoptimistic bias of projections because it derives from errors computed as actual minus projected growth. 
Appendix 4, Tables A4.1 to A4.4 break down results for the individual economies. For each of the reports, economies are ranked by decreasing size of average bias in the year-ahead forecasts. Clearly, there is a wide spectrum of bias. For example, in relation to ADO, Azerbaijan tops the list of overly optimistic forecasts (Table A4.1); an average error of -3.82 and a count measure of 0.83 indicates that year-ahead forecasts were far too sanguine, both in terms of average distance to actual growth and the number of years in which they remained unfulfilled. At the opposite extreme is Palau, with an error of 1.65 , because forecasts (fewer in number than for other economies) on average fell short of actual growth, and Tajikistan, with a count measure equal to zero because forecast errors are positive throughout. In between these extremes, there is much variation across economies. For example, ADO projections of PRC growth, in row 21 of Table A4.1, were overly optimistic, especially by count of the years when growth expectations were not met in reality.

\section{Asia-11-Growth and Inflation Forecasts}

The Asia-43 economies are highly heterogeneous and associated with a broad range of forecast errors. By contrast, the Asia-11 sample allows for a comparison of average errors and scores among a more compact group of economies. To recall, this includes the PRC and India-the largest emerging economies in the region - the Republic of Korea; Hong Kong, China; Singapore; and Taipei,China-the co-called Asian Tigers-as well as Indonesia, Malaysia, Thailand, the Philippines, and Viet Nam-the major Southeast Asian emerging economies.

Compared to Asia-43, Asia-11 errors across the reports are significantly smaller (Table 3). For example, year-ahead GDP forecasts across the sample were off by more than one-half of average growth during the 2007-2011 crisis years, and nearly by a third in the quinquennium from 2012. Current-year and year-ahead growth Brier scores are in favor of ADO versus WEO, but year-ahead growth scores see WEOU prevail over ADOU (Figure 3). On inflation, the IMF reports are ahead on most counts but, again, average differences do not seem to be particularly significant (Figure 4). Count scores only partly confirm, and the score board (Table 6) suggests that, by and large, they tilt the balance in favor of the IMF reports, mainly because of superior accuracy in the year-ahead forecasts.

Table 6 summarizes also the scores for the 11 economies individually, which are shown also in the charts in Appendix 6. Results are mixed, but for 7 out the 11 economies - including the PRC and India-WEOU reports are more accurate, if only so slightly. The pattern is less clear in relation to the main reports, where ADO's accuracy is higher across the board for a number of economies, including the Republic of Korea; Malaysia; and Taipei,China.

A more granular analysis, based on charts by economies and years in Appendix 6, provides additional insights. For example, charts in Figure A7.1 on the PRC show that ADO and WEO yearly forecasts resemble each other quite closely. Scores are determined not by a qualitative difference between the reports, but by somewhat larger discrepancies during specific years, such as 2007 and 2008, when ADOU projections where farther removed from actual growth rates.

To assess whether there are significant differences in the aggregate size of forecast errors over time, the Asia-11 sample is split into two 5-year periods. The first halve spans from 2007 to 2011, and the second from 2012 to 2016. Table 3 shows that average errors during the latter 5 years are roughly half the size of those during the earlier period, when the Asian region had to deal with the global economic crisis. A comparison of Brier and count scores for the entire decade and the two subperiods suggests that higher accuracy of WEO and especially WEOU reports over the entire decade is mainly reflective of the earlier period. Indeed, the period from 2012 onward scores mostly in favor of the ADO and ADOU reports, except for current-year growth estimates, where WEOU prevails (Tables 6 and 7). 
Table 6: Score Board

\begin{tabular}{|c|c|c|c|c|c|}
\hline \multirow[b]{2}{*}{ Group/Economy } & \multirow[b]{2}{*}{ Period } & \multicolumn{2}{|c|}{ Growth } & \multicolumn{2}{|c|}{ Inflation } \\
\hline & & Estimates & Forecasts & Estimates & Forecasts \\
\hline \multirow[t]{4}{*}{ Asia-43 } & $2007-2016$ & ADO & ADO & WEO & ADO \\
\hline & & ADOU & - & WEOU & WEOU \\
\hline & $2007-2016$ & - & ADO & WEO & - \\
\hline & & WEOU & WEOU & - & WEOU \\
\hline \multirow[t]{4}{*}{ Asia-11 } & 2007-2011 & ADO & ADO & WEO & WEO \\
\hline & & WEOU & WEOU & - & WEOU \\
\hline & $2012-2016$ & - & ADO & - & - \\
\hline & & WEOU & ADOU & ADOU & ADOU \\
\hline \multirow[t]{2}{*}{ PRC } & 2007-2016 & ADO & ADO & WEO & WEO \\
\hline & & WEOU & WEOU & WEOU & WEOU \\
\hline \multirow[t]{2}{*}{ HKG } & 2007-2016 & ADO & ADO & WEO & ADO \\
\hline & & WEOU & WEOU & ADOU & WEOU \\
\hline \multirow[t]{2}{*}{ INO } & 2007-2016 & ADO & ADO & WEO & WEO \\
\hline & & ADOU & WEOU & WEOU & ADOU \\
\hline \multirow[t]{2}{*}{ IND } & 2007-2016 & WEO & WEO & WEO & ADO \\
\hline & & WEOU & WEOU & WEOU & WEOU \\
\hline \multirow[t]{2}{*}{ KOR } & $2007-2016$ & ADO & ADO & ADO & ADO \\
\hline & & WEOU & WEOU & WEOU & WEOU \\
\hline \multirow[t]{2}{*}{ MAL } & 2007-2016 & ADO & ADO & ADO & ADO \\
\hline & & ADOU & ADOU & ADOU & ADOU \\
\hline \multirow[t]{2}{*}{$\mathrm{PHI}$} & $2007-2016$ & ADO & ADO & WEO & WEO \\
\hline & & ADOU & WEOU & WEOU & WEOU \\
\hline \multirow[t]{2}{*}{ SIN } & 2007-2016 & ADO & ADO & WEO & WEO \\
\hline & & WEOU & WEOU & WEOU & WEOU \\
\hline \multirow[t]{2}{*}{ THA } & 2007-2016 & WEO & ADO & ADO & WEO \\
\hline & & WEOU & WEOU & WEOU & WEOU \\
\hline \multirow[t]{2}{*}{ TAP } & 2007-2016 & ADO & ADO & ADO & ADO \\
\hline & & WEOU & WEOU & ADOU & ADOU \\
\hline \multirow[t]{4}{*}{ VIE } & 2007-2016 & ADO & ADO & ADO & WEO \\
\hline & & ADOU & ADOU & ADOU & WEOU \\
\hline & $2007-2016$ & WEO & WEO & n.a. & n.a. \\
\hline & & WEOU & WEOU & n.a. & n.a. \\
\hline \multirow[t]{4}{*}{ G3 } & 2007-2011 & WEO & WEO & n.a. & n.a. \\
\hline & & WEOU & WEOU & n.a. & n.a. \\
\hline & $2012-2016$ & WEO & ADO & n.a. & n.a. \\
\hline & & WEOU & WEOU & n.a. & n.a. \\
\hline
\end{tabular}

- = not available; $A D O=$ Asian Development Outlook; ADOU = Asian Development Outlook Update; G3 = euro area, Japan, and the United States; HKG = Hong Kong, China; IND = India; INO = Indonesia; $K O R=$ Republic of Korea; $M A L=$ Malaysia; n.a. = not applicable; $\mathrm{PHI}=$ Philippines; PRC = People's Republic of China, $\mathrm{SIN}=$ Singapore; TAP = Taipei,China; THA = Thailand; VIE = Viet Nam; WEO = World Economic Outlook; WEOU = World Economic Outlook Update.

Notes: Asia-43 and Asia-11,"-" indicates opposite Brier and Count scores. G3 and single economies, Brier only. Asia-43 refers to 45 developing member countries of ADB; Cook Islands and Nauru are excluded due to data issues. Asia-11 refers to Hong Kong, China; India; Indonesia; Malaysia; the People's Republic of China; the Philippines; the Republic of Korea; Singapore; Thailand; Taipei,China; and Viet Nam. Source: Author's calculations. 
Table 7: Asia-11, Brier, and Count Scores

\begin{tabular}{|c|c|c|c|c|}
\hline & \multicolumn{2}{|c|}{ Estimates } & \multicolumn{2}{|c|}{ Forecasts } \\
\hline & ADO/WEO & ADOU/WEOU & ADO/WEO & ADOU/WEOU \\
\hline \multicolumn{5}{|c|}{ GDP Growth, Brier Scores } \\
\hline 2007-2016 & 0.19 & -0.40 & 0.20 & -0.19 \\
\hline 2007-2011 & 0.21 & -0.49 & 0.23 & -0.23 \\
\hline $2012-2016$ & 0.04 & -0.02 & 0.02 & -0.03 \\
\hline \multicolumn{5}{|c|}{ GDP Growth, Count Scores } \\
\hline 2007-2016 & -0.06 & -0.14 & 0.03 & -0.27 \\
\hline 2007-2011 & 0.07 & -0.27 & 0.02 & -0.44 \\
\hline 2012-2016 & -0.20 & 0.00 & 0.04 & -0.11 \\
\hline \multicolumn{5}{|c|}{ CPI Inflation, Brier Scores } \\
\hline $2007-2016$ & -0.01 & -0.19 & -0.06 & -0.18 \\
\hline 2007-2011 & -0.15 & -1.28 & -0.06 & -0.24 \\
\hline 2012-2016 & 0.37 & 0.69 & -0.05 & 0.10 \\
\hline \multicolumn{5}{|c|}{ CPI Inflation, Count Scores } \\
\hline 2007-2016 & -0.13 & 0.15 & 0.01 & -0.15 \\
\hline 2007-2011 & -0.22 & 0.24 & -0.07 & -0.33 \\
\hline $2012-2016$ & -0.04 & 0.07 & 0.09 & 0.04 \\
\hline
\end{tabular}

$\mathrm{ADO}=$ Asian Development Outlook, $\mathrm{ADOU}=$ Asian Development Outlook Update, $\mathrm{CPI}=$ Consumer Price Index, GDP = gross domestic product, $\mathrm{WEO}=$ World Economic Outlook, WEOU = World Economic Outlook Update.

Note: Asia-11 refers to Hong Kong, China; India; Indonesia; Malaysia; the People's Republic of China; the Philippines; the Republic of Korea; Singapore; Thailand; Taipei,China; and Viet Nam.

Source: Author's calculations.

Similarly to Asia-43, Asia-11 forecast errors tend to shrink as more information becomes available over time, leading to a gradual correction of the projections (Figure 3 and Figure 4). For a closer assessment of this pattern in relation to ADO forecasts, July and December GDP and CPI forecasts from the ADO Supplement reports are added to the data set, with coverage from 2012 onward. In addition to the April and September releases of data, this brings to four the total number of projections available each year, and to eight over the period of 2 years, considering both year-ahead and current-year estimates. ${ }^{6}$ The full series of data, averaged across Asia-11, is shown in the bottom charts of Figure 3, on growth, and of Figure 4, on inflation. In either case, forecasts tend to sharpen considerably as new information becomes available and gets reflected in the quarterly updated reports. The same is true for individual economies, as suggested by the charts in Appendix 9. In part, this would explain smaller average errors observed in the IMF forecasts, which are usually released weeks later than ADB's thus incorporating the latest information, such as national accounts estimates and leading indicators.

6 For example, the ADO April 2012 report issued the earliest projections of 2013 growth forecasts, which then got updated eight times up until the release of the ADO Supplement in December 2013, with the latest projections prior to the availability of actual data in the quarter to follow. 
In sum, Asia-11 aggregate scores are prevalently in favor of the IMF reports, which tend to be more accurate. However, this applies mainly to projections in relation to the earlier period of heightened volatility, not otherwise. Average scores for the 5 years from 2012 suggest not only that errors were lower for all the reports, compared to 5 years earlier, but also that net differences were larger for ADO and ADOU reports, which improved accuracy more significantly. This is further corroborated by the marked fall of growth and inflation projection errors observed in relation to ADO quarterly projection updates, which display a correcting trend over time.

\section{E. G3-Euro Area, Japan, and the United States Growth Forecasts}

G3 forecast errors are smaller than those of both the Asia-43 and Asia-11 samples (Figure 5). Both Brier and count scores are clearly in favor of the WEO and WEOU projections, both in relation to current-year estimates and year-ahead forecasts.

Among G3, ADO euro area projections score the lowest. This is because the euro area has a higher relative discrepancy, compared to WEO and WEOU forecast errors, notwithstanding smaller absolute errors than Japan and the United States (Figure 6). Yearly averages further indicate that euro area growth projections are associated with large errors not only during 2009-2011, when also Japan and United States errors were high, but also afterwards, in 2012 and 2013, when the euro crisis seems to have caught forecasters by surprise (Appendix 8, Figures A8.1 to A8.3).

Japan has the largest average errors among G3, which seems partly justified by a higher coefficient of variation, of 5.6 during 2007-2016, compared to 3.2 for the euro area and 1.0 for the United States (Appendix 2). Against this backdrop, Japan's marginally positive ADO versus WEO score in year-ahead growth forecasts and a smaller negative ADOU versus WEOU score compare somewhat favorably against the other two economies (Figure 6).

Finally, the comparison of G3 forecast errors across the two subperiods, 2007-2011 and 20122016, shows that errors are significantly smaller in the latter period (Table 4). The same is true for the coefficient of variation, partly because of higher average growth. In both periods, ADO and ADOU errors are larger than those in WEO and WEOU, respectively. This translates into Brier scores that are mostly negative across both periods (Table 8 ) and the IMF reports' higher accuracy across G3 growth projections, with the only exception of year-ahead growth forecasts (Table 6).

Table 8: G3 Gross Domestic Product Growth Projections-Brier Scores, 2007-2016

\begin{tabular}{lccccc}
\hline & \multicolumn{3}{c}{ Estimates } & & \multicolumn{2}{c}{ Forecasts } \\
\cline { 2 - 3 } \cline { 5 - 6 } Period & ADO/WEO & ADOU/WEOU & & ADO/WEO & ADOU/WEOU \\
\hline $2007-2016$ & -0.45 & -0.27 & & -0.03 & -0.38 \\
$2007-2011$ & -0.57 & -0.30 & & -0.04 & -0.38 \\
$2012-2016$ & -0.02 & -0.21 & & 0.02 & -0.35 \\
\hline
\end{tabular}

$\mathrm{ADO}=$ Asian Development Outlook; ADOU = Asian Development Outlook Update; G3 = euro area, Japan, and the United States; WEO = World Economic Outlook; WEOU = World Economic Outlook Update.

Source: Author's calculations. 
In sum, WEO and WEOU growth projections for $\mathrm{G} 3$ economies tend to be more reliable than ADB's. Unlike the Asia-11 aggregate, where IMF projections were found to be more accurate mainly in the period spanning from 2007 to 2011 but not afterwards, for the G3 group of economies they are somewhat sharper than ADB's throughout much of the decade considered.

\section{CONCLUSIONS}

This paper assessed the comparative accuracy of ADO against the WEO yearly growth and inflation forecasts for 43 Asian economies from 2007 to 2016. Results are mixed, with one forecaster prevailing over the other in relation to different reference periods and economies. However, the two sets of forecasts are a fairly close match overall. Average errors are quite substantial, but projections do sharpen significantly as additional information gets incorporated closer to the reference dates. Indeed, there is strong evidence of progressively shrinking errors over forecasts' life span of 2 years, from the earliest year-ahead projections to the latest current-year estimates.

Both ADB and IMF projections are found to be somewhat optimistic and they often err in the same direction. Evidently, a shared set of models and assumptions about the main macroeconomic forces at play are reflected in similar projections. However, similar forecast numbers do not necessarily imply overlapping narratives. Besides the numbers as such, macroeconomic forecasting is about the way in which various available indicators and policy analyses are brought together within a coherent narrative that captures a forecaster's view about a country's short-run macro environment and prospects. It is within these narratives that certain differences and qualities are often observed in relation to the ADO and WEO reports, conferring a unique and special value to each. However, capturing these qualities is entirely beyond the reach of this paper. 


\section{APPENDIXES}

Appendix 1: Asia-43 Growth and Inflation Forecast Errors

Table A1.1: ADO GDP Average Forecast Errors by Descending Degree of Accuracy on RMSE1

\begin{tabular}{|c|c|c|c|c|c|c|c|}
\hline \multirow[b]{2}{*}{ Rank } & \multirow[b]{2}{*}{ ISO } & \multirow[b]{2}{*}{ Economy } & \multicolumn{2}{|c|}{ Current Year } & \multicolumn{2}{|c|}{ Year Ahead } & \multirow[b]{2}{*}{$\mathrm{CoV}$} \\
\hline & & & MAEO & RMSEO & MAE1 & RMSE1 & \\
\hline 1 & BAN & Bangladesh & 0.34 & 0.42 & 0.55 & 0.63 & 0.07 \\
\hline 2 & RMI & Marshall Islands & 1.83 & 2.08 & 0.67 & 0.71 & 0.65 \\
\hline 3 & TUV & Tuvalu & 0.37 & 0.57 & 0.67 & 0.87 & 0.55 \\
\hline 4 & LAO & Lao People's Democratic Republic & 0.48 & 0.68 & 0.67 & 0.88 & 0.06 \\
\hline 5 & INO & Indonesia & 0.44 & 0.52 & 0.90 & 1.03 & 0.13 \\
\hline 6 & KIR & Kiribati & 0.95 & 1.08 & 0.86 & 1.04 & 0.62 \\
\hline 7 & MYA & Myanmar & 0.95 & 1.25 & 1.13 & 1.33 & 0.15 \\
\hline 8 & VIE & Viet Nam & 0.45 & 0.50 & 1.04 & 1.35 & 0.16 \\
\hline 9 & PRC & People's Republic of China & 0.80 & 1.03 & 1.10 & 1.42 & 0.19 \\
\hline 10 & UZB & Uzbekistan & 0.73 & 0.96 & 1.02 & 1.47 & 0.06 \\
\hline 11 & PAK & Pakistan & 0.70 & 1.13 & 1.12 & 1.79 & 0.29 \\
\hline 12 & SRI & Sri Lanka & 0.99 & 1.21 & 1.67 & 1.88 & 0.25 \\
\hline 13 & NEP & Nepal & 0.81 & 1.05 & 1.35 & 1.92 & 0.41 \\
\hline 14 & $\mathrm{TON}$ & Tonga & 0.91 & 1.21 & 1.59 & 1.96 & 1.54 \\
\hline 15 & TAJ & Tajikistan & 1.26 & 1.61 & 1.70 & 2.10 & 0.20 \\
\hline 16 & GEO & Georgia & 1.43 & 2.00 & 1.74 & 2.13 & 0.39 \\
\hline 17 & KOR & Republic of Korea & 1.16 & 1.53 & 1.70 & 2.19 & 0.53 \\
\hline 18 & VAN & Vanuatu & 1.22 & 1.45 & 1.80 & 2.25 & 0.67 \\
\hline 19 & IND & India & 1.27 & 1.46 & 2.03 & 2.30 & 0.23 \\
\hline 20 & $\mathrm{PHI}$ & Philippines & 1.52 & 1.80 & 1.90 & 2.42 & 0.37 \\
\hline 21 & $\mathrm{BHU}$ & Bhutan & 1.57 & 2.22 & 1.88 & 2.52 & 0.48 \\
\hline 22 & TKM & Turkmenistan & 2.12 & 2.77 & 2.34 & 2.61 & 0.30 \\
\hline 23 & MAL & Malaysia & 0.87 & 1.06 & 1.40 & 2.61 & 0.52 \\
\hline 24 & FSM & Federated States of Micronesia & 1.72 & 1.80 & 2.38 & 2.88 & 34.83 \\
\hline 25 & BRU & Brunei Darussalam & 2.11 & 2.45 & 2.29 & 2.90 & -8.04 \\
\hline 26 & SAM & Samoa & 1.49 & 2.09 & 2.29 & 3.14 & 2.17 \\
\hline 27 & HKG & Hong Kong, China & 0.94 & 1.14 & 2.46 & 3.17 & 0.95 \\
\hline 28 & CAM & Cambodia & 0.95 & 1.59 & 2.04 & 3.28 & 0.49 \\
\hline 29 & $\mathrm{FIJ}$ & Fiji & 1.65 & 1.84 & 2.62 & 3.28 & 2.49 \\
\hline 30 & KAZ & Kazakhstan & 1.28 & 1.77 & 3.02 & 3.58 & 0.62 \\
\hline 31 & THA & Thailand & 1.78 & 2.26 & 3.09 & 3.67 & 1.01 \\
\hline 32 & SOL & Solomon Islands & 2.22 & 2.85 & 3.10 & 3.87 & 0.80 \\
\hline 33 & KGZ & Kyrgyz Republic & 3.19 & 3.85 & 3.39 & 4.06 & 0.89 \\
\hline 34 & TAP & Taipei,China & 2.22 & 2.78 & 3.31 & 4.26 & 1.27 \\
\hline 35 & MLD & Maldives & 2.65 & 3.18 & 3.37 & 4.39 & 0.80 \\
\hline 36 & TIM & Timor-Leste & 2.07 & 2.75 & 3.52 & 4.57 & 0.37 \\
\hline 37 & SIN & Singapore & 2.31 & 3.27 & 3.41 & 4.69 & 1.14 \\
\hline 38 & PNG & Papua New Guinea & 1.80 & 2.56 & 3.34 & 4.73 & 0.33 \\
\hline 39 & AFG & Afghanistan & 3.26 & 5.04 & 3.74 & 5.25 & 0.94 \\
\hline 40 & AZE & Azerbaijan & 2.78 & 3.17 & 4.66 & 5.37 & 1.34 \\
\hline 41 & PAL & Palau & 1.25 & 1.26 & 5.75 & 5.98 & 0.94 \\
\hline 42 & MON & Mongolia & 2.70 & 3.46 & 5.80 & 6.53 & 0.76 \\
\hline 43 & ARM & Armenia & 3.17 & 5.11 & 4.34 & 7.61 & 2.33 \\
\hline
\end{tabular}

$\mathrm{ADO}=$ Asian Development Outlook, $\mathrm{CoV}=$ coefficient of variation, $\mathrm{GDP}=$ gross domestic product, ISO = International Organization for Standardization, $\mathrm{MAE}=$ mean absolute error, $\mathrm{RMSE}=$ root mean squared error.

Source: Author's calculations. 
Table A1.2: WEO GDP Average Forecast Errors by Descending Degree of Accuracy on RMSE1

\begin{tabular}{|c|c|c|c|c|c|c|c|}
\hline \multirow[b]{2}{*}{ Rank } & \multirow[b]{2}{*}{ ISO } & \multirow[b]{2}{*}{ Economy } & \multicolumn{2}{|c|}{ Current Year } & \multicolumn{2}{|c|}{ Year Ahead } & \multirow[b]{2}{*}{$\mathrm{CoV}$} \\
\hline & & & MAEO & RMSEO & MAE1 & RMSE1 & \\
\hline 1 & BAN & Bangladesh & 0.41 & 0.47 & 0.44 & 0.51 & 0.07 \\
\hline 2 & TUV & Tuvalu & 0.45 & 0.52 & 0.63 & 0.79 & 0.55 \\
\hline 3 & INO & Indonesia & 0.42 & 0.69 & 0.92 & 1.19 & 0.13 \\
\hline 4 & RMI & Marshall Islands & 1.20 & 1.62 & 1.03 & 1.30 & 0.65 \\
\hline 5 & LAO & $\begin{array}{l}\text { Lao People's Democratic } \\
\text { Republic }\end{array}$ & 0.65 & 0.96 & 1.07 & 1.32 & 0.06 \\
\hline 6 & VIE & Viet Nam & 0.66 & 0.84 & 1.28 & 1.45 & 0.16 \\
\hline 7 & PRC & People's Republic of China & 0.68 & 1.05 & 1.18 & 1.51 & 0.19 \\
\hline 8 & FSM & Federated States of Micronesia & 1.05 & 1.47 & 1.02 & 1.52 & 34.83 \\
\hline 9 & MYA & Myanmar & 0.98 & 1.32 & 1.35 & 1.53 & 0.15 \\
\hline 10 & KIR & Kiribati & 0.68 & 0.92 & 1.24 & 1.55 & 0.62 \\
\hline 11 & NEP & Nepal & 0.92 & 1.09 & 1.09 & 1.75 & 0.41 \\
\hline 12 & PAK & Pakistan & 0.67 & 1.07 & 1.13 & 1.83 & 0.29 \\
\hline 13 & SRI & Sri Lanka & 1.13 & 1.29 & 1.51 & 1.92 & 0.25 \\
\hline 14 & UZB & Uzbekistan & 1.36 & 1.49 & 1.65 & 1.92 & 0.06 \\
\hline 15 & TON & Tonga & 1.15 & 1.45 & 1.55 & 1.95 & 1.54 \\
\hline 16 & IND & India & 1.18 & 1.43 & 1.87 & 2.16 & 0.23 \\
\hline 17 & GEO & Georgia & 1.43 & 2.08 & 1.96 & 2.20 & 0.39 \\
\hline 18 & TAJ & Tajikistan & 1.89 & 2.28 & 1.90 & 2.25 & 0.20 \\
\hline 19 & KOR & Republic of Korea & 1.23 & 1.69 & 1.87 & 2.34 & 0.53 \\
\hline 20 & VAN & Vanuatu & 1.52 & 1.71 & 2.05 & 2.50 & 0.67 \\
\hline 21 & $\mathrm{PHI}$ & Philippines & 1.55 & 1.85 & 2.11 & 2.88 & 0.37 \\
\hline 22 & MAL & Malaysia & 0.87 & 1.13 & 1.65 & 2.95 & 0.52 \\
\hline 23 & $\mathrm{BHU}$ & Bhutan & 1.49 & 1.61 & 2.46 & 3.05 & 0.48 \\
\hline 24 & FIJ & Fiji & 2.05 & 2.77 & 2.55 & 3.21 & 2.49 \\
\hline 25 & CAM & Cambodia & 0.92 & 1.29 & 1.97 & 3.33 & 0.49 \\
\hline 26 & $\mathrm{SOL}$ & Solomon Islands & 2.85 & 3.52 & 2.80 & 3.38 & 0.80 \\
\hline 27 & SAM & Samoa & 2.62 & 3.47 & 2.73 & 3.52 & 2.17 \\
\hline 28 & TKM & Turkmenistan & 2.36 & 2.87 & 3.16 & 3.53 & 0.30 \\
\hline 29 & HKG & Hong Kong, China & 1.00 & 1.20 & 2.75 & 3.56 & 0.95 \\
\hline 30 & KAZ & Kazakhstan & 1.62 & 2.08 & 2.89 & 3.62 & 0.62 \\
\hline 31 & MLD & Maldives & 2.04 & 2.54 & 3.05 & 3.64 & 0.80 \\
\hline 32 & KGZ & Kyrgyz Republic & 2.23 & 3.00 & 3.02 & 3.67 & 0.89 \\
\hline 33 & THA & Thailand & 1.69 & 2.07 & 3.47 & 4.24 & 1.01 \\
\hline 34 & $\mathrm{BRU}$ & Brunei Darussalam & 2.33 & 3.34 & 3.60 & 4.29 & -8.04 \\
\hline 35 & TAP & Taipei,China & 2.33 & 2.87 & 3.56 & 4.63 & 1.27 \\
\hline 36 & PNG & Papua New Guinea & 2.17 & 3.71 & 3.61 & 5.00 & 0.33 \\
\hline 37 & PAL & Palau & 3.65 & 5.09 & 4.00 & 5.12 & 0.94 \\
\hline 38 & SIN & Singapore & 2.81 & 4.17 & 3.65 & 5.44 & 1.14 \\
\hline 39 & MON & Mongolia & 2.99 & 3.75 & 4.54 & 5.51 & 0.76 \\
\hline 40 & TIM & Timor-Leste & 3.14 & 4.31 & 4.25 & 5.54 & 0.37 \\
\hline 41 & AZE & Azerbaijan & 2.98 & 3.82 & 4.42 & 5.56 & 1.34 \\
\hline 42 & AFG & Afghanistan & 3.20 & 5.00 & 4.16 & 5.63 & 0.94 \\
\hline 43 & ARM & Armenia & 2.83 & 3.87 & 4.03 & 7.57 & 2.33 \\
\hline
\end{tabular}

$\mathrm{CoV}=$ coefficient of variation, $\mathrm{GDP}=$ gross domestic product, ISO = International Organization for Standardization, MAE = mean absolute error, $\mathrm{RMSE}=$ root mean squared error, $\mathrm{WEO}=$ World Economic Outlook.

Source: Author's calculations. 
Table A1.3: ADOU GDP Average Forecast Errors by Descending Degree of Accuracy on RMSE1

\begin{tabular}{|c|c|c|c|c|c|c|c|}
\hline \multirow[b]{2}{*}{ Rank } & \multirow[b]{2}{*}{ ISO } & \multirow[b]{2}{*}{ Economy } & \multicolumn{2}{|c|}{ Current Year } & \multicolumn{2}{|c|}{ Year Ahead } & \multirow[b]{2}{*}{$\mathrm{CoV}$} \\
\hline & & & MAEO & RMSEO & MAE1 & RMSE1 & \\
\hline 1 & BAN & Bangladesh & 0.14 & 0.16 & 0.50 & 0.58 & 0.07 \\
\hline 2 & RMI & Marshall Islands & 1.83 & 2.08 & 0.67 & 0.71 & 0.65 \\
\hline 3 & INO & Indonesia & 0.11 & 0.14 & 0.70 & 0.82 & 0.13 \\
\hline 4 & TUV & Tuvalu & 0.43 & 0.57 & 0.65 & 0.86 & 0.55 \\
\hline 5 & LAO & $\begin{array}{l}\text { Lao People's Democratic } \\
\text { Republic }\end{array}$ & 0.44 & 0.65 & 0.64 & 0.86 & 0.06 \\
\hline 6 & KIR & Kiribati & 0.84 & 0.94 & 0.86 & 1.01 & 0.62 \\
\hline 7 & VIE & Viet Nam & 0.25 & 0.30 & 0.84 & 1.03 & 0.16 \\
\hline 8 & PRC & People's Republic of China & 0.38 & 0.54 & 0.86 & 1.16 & 0.19 \\
\hline 9 & MYA & Myanmar & 0.93 & 1.24 & 1.13 & 1.29 & 0.15 \\
\hline 10 & PAK & Pakistan & 0.56 & 0.94 & 0.93 & 1.39 & 0.29 \\
\hline 11 & UZB & Uzbekistan & 0.69 & 0.83 & 0.97 & 1.42 & 0.06 \\
\hline 12 & TON & Tonga & 0.74 & 1.10 & 1.40 & 1.61 & 1.54 \\
\hline 13 & SRI & Sri Lanka & 0.74 & 0.94 & 1.54 & 1.78 & 0.25 \\
\hline 14 & NEP & Nepal & 0.42 & 0.48 & 1.25 & 1.82 & 0.41 \\
\hline 15 & IND & India & 0.76 & 0.93 & 1.73 & 1.99 & 0.23 \\
\hline 16 & KOR & Republic of Korea & 0.75 & 1.10 & 1.57 & 2.03 & 0.53 \\
\hline 17 & $\mathrm{PHI}$ & Philippines & 0.62 & 0.75 & 1.77 & 2.21 & 0.37 \\
\hline 18 & VAN & Vanuatu & 0.77 & 0.95 & 1.81 & 2.21 & 0.67 \\
\hline 19 & TAJ & Tajikistan & 1.64 & 1.97 & 1.74 & 2.24 & 0.20 \\
\hline 20 & GEO & Georgia & 0.79 & 1.01 & 2.03 & 2.39 & 0.39 \\
\hline 21 & FSM & Federated States of Micronesia & 1.18 & 1.46 & 2.02 & 2.45 & 34.83 \\
\hline 22 & $\mathrm{BHU}$ & Bhutan & 1.45 & 2.10 & 1.86 & 2.50 & 0.48 \\
\hline 23 & MAL & Malaysia & 0.59 & 0.71 & 1.51 & 2.50 & 0.52 \\
\hline 24 & BRU & Brunei Darussalam & 1.91 & 2.32 & 2.11 & 2.63 & -8.04 \\
\hline 25 & TKM & Turkmenistan & 2.01 & 2.57 & 2.45 & 2.88 & 0.30 \\
\hline 26 & CAM & Cambodia & 0.42 & 0.59 & 1.91 & 2.99 & 0.49 \\
\hline 27 & HKG & Hong Kong, China & 0.63 & 0.90 & 2.32 & 3.07 & 0.95 \\
\hline 28 & SAM & Samoa & 1.23 & 1.49 & 2.31 & 3.11 & 2.17 \\
\hline 29 & FIJ & Fiji & 1.27 & 1.40 & 2.53 & 3.21 & 2.49 \\
\hline 30 & $K G Z$ & Kyrgyz Republic & 1.53 & 1.80 & 2.73 & 3.31 & 0.89 \\
\hline 31 & KAZ & Kazakhstan & 1.11 & 1.33 & 2.76 & 3.33 & 0.62 \\
\hline 32 & THA & Thailand & 1.21 & 1.65 & 3.02 & 3.60 & 1.01 \\
\hline 33 & $\mathrm{SOL}$ & Solomon Islands & 1.69 & 2.13 & 3.15 & 3.93 & 0.80 \\
\hline 34 & TAP & Taipei,China & 1.48 & 1.99 & 3.08 & 4.03 & 1.27 \\
\hline 35 & MLD & Maldives & 1.44 & 2.18 & 3.20 & 4.14 & 0.80 \\
\hline 36 & TIM & Timor-Leste & 2.33 & 2.98 & 3.49 & 4.49 & 0.37 \\
\hline 37 & PNG & Papua New Guinea & 0.88 & 1.19 & 2.94 & 4.50 & 0.33 \\
\hline 38 & SIN & Singapore & 1.12 & 1.64 & 3.16 & 4.54 & 1.14 \\
\hline 39 & AZE & Azerbaijan & 2.52 & 3.00 & 3.96 & 4.59 & 1.34 \\
\hline 40 & AFG & Afghanistan & 2.29 & 3.16 & 3.76 & 5.37 & 0.94 \\
\hline 41 & MON & Mongolia & 1.67 & 2.41 & 4.26 & 5.45 & 0.76 \\
\hline 42 & PAL & Palau & 0.35 & 0.43 & 7.25 & 7.25 & 0.94 \\
\hline 43 & ARM & Armenia & 2.31 & 2.67 & 4.23 & 7.59 & 2.33 \\
\hline
\end{tabular}

$\mathrm{ADOU}=$ Asian Development Outlook Update, $\mathrm{CoV}=$ coefficient of variation, $\mathrm{GDP}=$ gross domestic product, ISO = International Organization for Standardization, MAE = mean absolute error, RMSE = root mean squared error Source: Author's calculations. 
Table A1.4: WEOU GDP Average Forecast Errors by Descending Degree of Accuracy on RMSE1

\begin{tabular}{|c|c|c|c|c|c|c|c|}
\hline \multirow[b]{2}{*}{ Rank } & \multirow[b]{2}{*}{ ISO } & \multirow[b]{2}{*}{ Economy } & \multicolumn{2}{|c|}{ Current Year } & \multicolumn{2}{|c|}{ Year Ahead } & \multirow[b]{2}{*}{$\mathrm{CoV}$} \\
\hline & & & MAEO & RMSEO & MAE1 & RMSE1 & \\
\hline 1 & BAN & Bangladesh & 0.32 & 0.40 & 0.24 & 0.33 & 0.07 \\
\hline 2 & TUV & Tuvalu & 0.35 & 0.39 & 0.51 & 0.58 & 0.55 \\
\hline 3 & INO & Indonesia & 0.19 & 0.25 & 0.48 & 0.62 & 0.13 \\
\hline 4 & PRC & People's Republic of China & 0.26 & 0.34 & 0.71 & 0.93 & 0.19 \\
\hline 5 & LAO & Lao People's Democratic Republic & 0.56 & 0.88 & 0.70 & 0.96 & 0.06 \\
\hline 6 & VIE & Viet Nam & 0.24 & 0.31 & 0.91 & 1.06 & 0.16 \\
\hline 7 & RMI & Marshall Islands & 1.23 & 1.62 & 1.03 & 1.30 & 0.65 \\
\hline 8 & PAK & Pakistan & 0.59 & 0.97 & 0.89 & 1.31 & 0.29 \\
\hline 9 & KIR & Kiribati & 0.54 & 0.86 & 1.06 & 1.39 & 0.62 \\
\hline 10 & FSM & Federated States of Micronesia & 1.22 & 1.53 & 0.88 & 1.39 & 34.83 \\
\hline 11 & MYA & Myanmar & 0.87 & 1.14 & 1.33 & 1.46 & 0.15 \\
\hline 12 & UZB & Uzbekistan & 1.04 & 1.09 & 1.40 & 1.48 & 0.06 \\
\hline 13 & SRI & Sri Lanka & 0.81 & 0.94 & 1.27 & 1.51 & 0.25 \\
\hline 14 & TON & Tonga & 1.01 & 1.33 & 1.30 & 1.59 & 1.54 \\
\hline 15 & NEP & Nepal & 0.46 & 0.58 & 1.22 & 1.71 & 0.41 \\
\hline 16 & KOR & Republic of Korea & 0.52 & 0.77 & 1.51 & 1.82 & 0.53 \\
\hline 17 & IND & India & 0.82 & 0.93 & 1.66 & 1.91 & 0.23 \\
\hline 18 & $\mathrm{PHI}$ & Philippines & 0.61 & 0.81 & 1.69 & 2.10 & 0.37 \\
\hline 19 & TAJ & Tajikistan & 1.19 & 1.41 & 1.87 & 2.27 & 0.20 \\
\hline 20 & GEO & Georgia & 0.74 & 0.83 & 1.90 & 2.37 & 0.39 \\
\hline 21 & VAN & Vanuatu & 0.75 & 0.87 & 2.13 & 2.44 & 0.67 \\
\hline 22 & MAL & Malaysia & 0.59 & 0.84 & 1.50 & 2.59 & 0.52 \\
\hline 23 & HKG & Hong Kong, China & 0.69 & 0.83 & 2.02 & 2.67 & 0.95 \\
\hline 24 & CAM & Cambodia & 0.47 & 0.62 & 1.69 & 2.89 & 0.49 \\
\hline 25 & KAZ & Kazakhstan & 1.12 & 1.44 & 2.38 & 2.93 & 0.62 \\
\hline 26 & FIJ & Fiji & 1.12 & 1.33 & 2.40 & 3.09 & 2.49 \\
\hline 27 & KGZ & Kyrgyz Republic & 1.36 & 1.60 & 2.69 & 3.32 & 0.89 \\
\hline 28 & SAM & Samoa & 1.63 & 2.16 & 2.40 & 3.35 & 2.17 \\
\hline 29 & THA & Thailand & 0.96 & 1.42 & 2.79 & 3.40 & 1.01 \\
\hline 30 & TAP & Taipei,China & 1.28 & 1.67 & 2.70 & 3.40 & 1.27 \\
\hline 31 & $\mathrm{BHU}$ & Bhutan & 1.96 & 2.31 & 2.47 & 3.45 & 0.48 \\
\hline 32 & TKM & Turkmenistan & 1.75 & 2.27 & 3.08 & 3.62 & 0.30 \\
\hline 33 & SOL & Solomon Islands & 2.01 & 2.68 & 2.96 & 3.62 & 0.80 \\
\hline 34 & MLD & Maldives & 1.35 & 1.94 & 3.20 & 4.04 & 0.80 \\
\hline 35 & SIN & Singapore & 0.74 & 1.08 & 2.99 & 4.19 & 1.14 \\
\hline 36 & PNG & Papua New Guinea & 1.19 & 1.69 & 3.17 & 4.34 & 0.33 \\
\hline 37 & $\mathrm{BRU}$ & Brunei Darussalam & 2.64 & 3.46 & 3.61 & 4.39 & -8.04 \\
\hline 38 & PAL & Palau & 3.65 & 4.05 & 4.00 & 5.12 & 0.94 \\
\hline 39 & TIM & Timor-Leste & 2.36 & 3.98 & 3.53 & 5.14 & 0.37 \\
\hline 40 & AFG & Afghanistan & 2.49 & 3.48 & 3.56 & 5.30 & 0.94 \\
\hline 41 & AZE & Azerbaijan & 2.20 & 2.67 & 4.52 & 5.43 & 1.34 \\
\hline 42 & MON & Mongolia & 1.57 & 2.25 & 4.62 & 5.56 & 0.76 \\
\hline 43 & ARM & Armenia & 1.74 & 2.11 & 4.14 & 7.61 & 2.33 \\
\hline
\end{tabular}

$\mathrm{CoV}=$ coefficient of variation, GDP = gross domestic product, $\mathrm{ISO}=$ International Organization for Standardization, MAE = mean absolute error, RMSE = root mean squared error, WEOU = World Economic Outlook Update.

Source: Author's calculations. 
Table A1.5: ADO CPI Average Forecast Errors by Descending Degree of Accuracy on RMSE1

\begin{tabular}{|c|c|c|c|c|c|c|c|}
\hline \multirow[b]{2}{*}{ Rank } & \multirow[b]{2}{*}{ ISO } & \multirow[b]{2}{*}{ Economy } & \multicolumn{2}{|c|}{ Current Year } & \multicolumn{2}{|c|}{ Year Ahead } & \multirow[b]{2}{*}{$\mathrm{CoV}$} \\
\hline & & & MAEO & RMSEO & MAE1 & RMSE1 & \\
\hline 1 & BRU & Brunei Darussalam & 0.71 & 0.77 & 0.98 & 1.07 & 2.52 \\
\hline 2 & TAP & Taipei,China & 0.76 & 0.89 & 0.98 & 1.24 & 1.02 \\
\hline 3 & KOR & Republic of Korea & 0.65 & 0.76 & 1.14 & 1.29 & 0.56 \\
\hline 4 & MAL & Malaysia & 0.78 & 1.06 & 1.11 & 1.34 & 0.53 \\
\hline 5 & HKG & Hong Kong, China & 0.48 & 0.58 & 1.11 & 1.37 & 0.45 \\
\hline 6 & TUV & Tuvalu & 0.87 & 1.23 & 1.35 & 1.49 & 0.35 \\
\hline 7 & BAN & Bangladesh & 0.71 & 0.89 & 1.32 & 1.58 & 0.18 \\
\hline 8 & INO & Indonesia & 1.10 & 1.32 & 1.59 & 1.78 & 0.29 \\
\hline 9 & VAN & Vanuatu & 1.78 & 1.97 & 1.87 & 2.05 & 0.69 \\
\hline 10 & $\mathrm{PHI}$ & Philippines & 1.30 & 1.94 & 1.64 & 2.13 & 0.59 \\
\hline 11 & THA & Thailand & 0.71 & 0.84 & 1.82 & 2.24 & 1.01 \\
\hline 12 & PRC & People's Republic of China & 0.93 & 1.22 & 2.20 & 2.62 & 0.68 \\
\hline 13 & $\mathrm{BHU}$ & Bhutan & 1.44 & 2.02 & 2.49 & 2.63 & 0.29 \\
\hline 14 & FSM & Federated States of Micronesia & 1.57 & 2.11 & 2.70 & 2.70 & -5.57 \\
\hline 15 & SIN & Singapore & 1.04 & 1.26 & 2.28 & 2.74 & 0.99 \\
\hline 16 & NEP & Nepal & 0.87 & 1.19 & 2.05 & 2.75 & 0.21 \\
\hline 17 & ARM & Armenia & 2.28 & 2.77 & 2.12 & 2.78 & 0.67 \\
\hline 18 & TON & Tonga & 2.51 & 3.21 & 2.15 & 2.80 & 0.91 \\
\hline 19 & LAO & Lao People's Democratic Republic & 1.38 & 2.01 & 2.16 & 2.82 & 0.53 \\
\hline 20 & IND & India & 1.88 & 2.64 & 2.30 & 2.92 & 0.28 \\
\hline 21 & RMI & Marshall Islands & 2.47 & 2.90 & 2.93 & 2.99 & -2.15 \\
\hline 22 & FIJ & Fiji & 2.18 & 2.62 & 2.42 & 3.01 & 0.61 \\
\hline 23 & PAL & Palau & 1.93 & 2.06 & 2.38 & 3.22 & 4.51 \\
\hline 24 & PNG & Papua New Guinea & 1.93 & 2.59 & 2.51 & 3.36 & 0.49 \\
\hline 25 & MYA & Myanmar & 2.35 & 2.66 & 2.65 & 3.42 & 0.47 \\
\hline 26 & UZB & Uzbekistan & 2.19 & 2.40 & 3.17 & 3.52 & 0.20 \\
\hline 27 & SAM & Samoa & 2.32 & 2.68 & 3.18 & 3.66 & 1.28 \\
\hline 28 & SOL & Solomon Islands & 3.05 & 4.29 & 2.61 & 3.79 & 0.83 \\
\hline 29 & GEO & Georgia & 2.30 & 2.86 & 3.04 & 3.95 & 1.06 \\
\hline 30 & $\mathrm{KIR}$ & Kiribati & 3.19 & 4.65 & 3.11 & 4.05 & 2.95 \\
\hline 31 & KAZ & Kazakhstan & 1.59 & 2.13 & 3.18 & 4.39 & 0.45 \\
\hline 32 & TKM & Turkmenistan & 2.91 & 4.93 & 2.98 & 4.56 & 0.71 \\
\hline 33 & MLD & Maldives & 3.12 & 3.79 & 4.36 & 5.04 & 0.74 \\
\hline 34 & PAK & Pakistan & 1.28 & 1.68 & 4.45 & 5.85 & 0.51 \\
\hline 35 & TAJ & Tajikistan & 3.66 & 4.35 & 4.26 & 6.04 & 0.58 \\
\hline 36 & TIM & Timor-Leste & 3.58 & 4.48 & 5.48 & 6.13 & 1.02 \\
\hline 37 & SRI & Sri Lanka & 2.23 & 3.18 & 4.14 & 6.19 & 0.82 \\
\hline 38 & AZE & Azerbaijan & 3.80 & 5.15 & 5.92 & 6.91 & 0.95 \\
\hline 39 & CAM & Cambodia & 3.34 & 6.70 & 3.81 & 7.19 & 1.33 \\
\hline 40 & VIE & Viet Nam & 2.08 & 2.67 & 5.70 & 7.21 & 0.78 \\
\hline 41 & MON & Mongolia & 4.38 & 6.25 & 4.72 & 7.31 & 0.66 \\
\hline 42 & KGZ & Kyrgyz Republic & 4.72 & 6.14 & 5.86 & 7.90 & 0.77 \\
\hline 43 & AFG & Afghanistan & 5.74 & 8.49 & 7.38 & 10.29 & 1.48 \\
\hline
\end{tabular}

$\mathrm{ADO}=$ Asian Development Outlook, $\mathrm{CoV}=$ coefficient of variation, $\mathrm{CPI}=$ Consumer Price Index, ISO = International Organization for Standardization, $\mathrm{MAE}=$ mean absolute error, $\mathrm{RMSE}=$ root mean squared error .

Source: Author's calculations. 
Table A1.6: WEO CPI Average Forecast Errors by Descending Degree of Accuracy on RMSE1

\begin{tabular}{|c|c|c|c|c|c|c|c|}
\hline \multirow[b]{2}{*}{ Rank } & \multirow[b]{2}{*}{ ISO } & \multirow[b]{2}{*}{ Economy } & \multicolumn{2}{|c|}{ Current Year } & \multicolumn{2}{|c|}{ Year Ahead } & \multirow[b]{2}{*}{$\mathrm{CoV}$} \\
\hline & & & MAEO & RMSEO & MAE1 & RMSE1 & \\
\hline 1 & TUV & Tuvalu & 0.67 & 0.74 & 0.51 & 0.54 & 0.35 \\
\hline 2 & BRU & Brunei Darussalam & 0.84 & 0.87 & 0.86 & 1.06 & 2.52 \\
\hline 3 & TAP & Taipei,China & 0.82 & 0.96 & 0.91 & 1.30 & 1.02 \\
\hline 4 & MAL & Malaysia & 0.75 & 1.10 & 1.20 & 1.40 & 0.53 \\
\hline 5 & KOR & Republic of Korea & 0.69 & 0.83 & 1.20 & 1.43 & 0.56 \\
\hline 6 & VAN & Vanuatu & 1.25 & 1.46 & 1.49 & 1.67 & 0.69 \\
\hline 7 & INO & Indonesia & 1.01 & 1.31 & 1.31 & 1.78 & 0.29 \\
\hline 8 & HKG & Hong Kong, China & 0.38 & 0.45 & 1.52 & 1.97 & 0.45 \\
\hline 9 & BAN & Bangladesh & 0.75 & 1.00 & 1.72 & 1.97 & 0.18 \\
\hline 10 & THA & Thailand & 0.72 & 0.95 & 1.66 & 2.03 & 1.01 \\
\hline 11 & $\mathrm{PHI}$ & Philippines & 0.93 & 1.66 & 1.55 & 2.06 & 0.59 \\
\hline 12 & PRC & People's Republic of China & 0.65 & 0.96 & 1.98 & 2.41 & 0.68 \\
\hline 13 & PAL & Palau & 2.03 & 2.60 & 2.22 & 2.41 & 4.51 \\
\hline 14 & $\mathrm{SIN}$ & Singapore & 1.08 & 1.20 & 2.15 & 2.56 & 0.99 \\
\hline 15 & ARM & Armenia & 1.71 & 2.01 & 2.13 & 2.67 & 0.67 \\
\hline 16 & UZB & Uzbekistan & 1.21 & 1.36 & 2.14 & 2.72 & 0.20 \\
\hline 17 & $\mathrm{BHU}$ & Bhutan & 1.71 & 1.97 & 2.39 & 2.73 & 0.29 \\
\hline 18 & RMI & Marshall Islands & 0.70 & 0.95 & 2.43 & 2.76 & -2.15 \\
\hline 19 & FIJ & Fiji & 1.88 & 2.67 & 2.35 & 2.93 & 0.61 \\
\hline 20 & FSM & Federated States of Micronesia & 1.57 & 1.90 & 2.87 & 2.94 & -5.57 \\
\hline 21 & LAO & Lao People's Democratic Republic & 1.12 & 1.39 & 2.34 & 2.99 & 0.53 \\
\hline 22 & TON & Tonga & 3.02 & 3.93 & 2.65 & 3.09 & 0.91 \\
\hline 23 & PNG & Papua New Guinea & 2.21 & 2.86 & 2.41 & 3.15 & 0.49 \\
\hline 24 & IND & India & 1.65 & 1.90 & 2.93 & 3.49 & 0.28 \\
\hline 25 & SAM & Samoa & 1.72 & 2.33 & 3.04 & 3.49 & 1.28 \\
\hline 26 & SOL & Solomon Islands & 2.74 & 3.82 & 2.42 & 3.50 & 0.83 \\
\hline 27 & MYA & Myanmar & 2.32 & 2.60 & 2.82 & 3.53 & 0.47 \\
\hline 28 & NEP & Nepal & 0.88 & 1.17 & 2.60 & 3.62 & 0.21 \\
\hline 29 & MLD & Maldives & 1.78 & 2.63 & 3.25 & 3.85 & 0.74 \\
\hline 30 & $\mathrm{KIR}$ & Kiribati & 2.55 & 3.24 & 3.27 & 3.92 & 2.95 \\
\hline 31 & GEO & Georgia & 2.07 & 2.31 & 3.41 & 4.43 & 1.06 \\
\hline 32 & KAZ & Kazakhstan & 1.24 & 1.48 & 3.08 & 4.62 & 0.45 \\
\hline 33 & TKM & Turkmenistan & 2.22 & 3.97 & 3.07 & 5.07 & 0.71 \\
\hline 34 & TAJ & Tajikistan & 2.70 & 3.39 & 4.14 & 5.27 & 0.58 \\
\hline 35 & TIM & Timor-Leste & 3.51 & 4.37 & 4.99 & 5.61 & 1.02 \\
\hline 36 & PAK & Pakistan & 1.02 & 1.40 & 4.72 & 5.86 & 0.51 \\
\hline 37 & VIE & Viet Nam & 2.88 & 3.40 & 4.76 & 6.61 & 0.78 \\
\hline 38 & SRI & Sri Lanka & 2.40 & 3.89 & 4.96 & 6.70 & 0.82 \\
\hline 39 & CAM & Cambodia & 2.96 & 5.50 & 4.05 & 7.24 & 1.33 \\
\hline 40 & AZE & Azerbaijan & 2.35 & 2.75 & 5.51 & 7.37 & 0.95 \\
\hline 41 & MON & Mongolia & 4.20 & 6.13 & 5.11 & 7.73 & 0.66 \\
\hline 42 & KGZ & Kyrgyz Republic & 3.31 & 3.83 & 5.59 & 8.11 & 0.77 \\
\hline 43 & AFG & Afghanistan & 4.99 & 6.96 & 7.59 & 10.43 & 1.48 \\
\hline
\end{tabular}

$\mathrm{CoV}=$ coefficient of variation, $\mathrm{CPI}=$ Consumer Price Index, ISO = International Organization for Standardization, $\mathrm{MAE}=$ mean absolute error, $\mathrm{RMSE}=$ root mean squared error, $\mathrm{WEO}=$ World Economic Outlook.

Source: Author's calculations. 
Table A1.7: ADOU CPI Average Forecast Errors by Descending Degree of Accuracy on RMSE1

\begin{tabular}{|c|c|c|c|c|c|c|c|}
\hline \multirow[b]{2}{*}{ Rank } & \multirow[b]{2}{*}{ ISO } & \multirow[b]{2}{*}{ Economy } & \multicolumn{2}{|c|}{ Current Year } & \multicolumn{2}{|c|}{ Year Ahead } & \multirow[b]{2}{*}{$\mathrm{CoV}$} \\
\hline & & & MAEO & RMSEO & MAE1 & RMSE1 & \\
\hline 1 & BRU & Brunei Darussalam & 0.45 & 0.51 & 0.85 & 1.01 & 2.52 \\
\hline 2 & TUV & Tuvalu & 0.97 & 1.11 & 1.01 & 1.12 & 0.35 \\
\hline 3 & KOR & Republic of Korea & 0.29 & 0.39 & 1.14 & 1.25 & 0.56 \\
\hline 4 & TAP & Taipei,China & 0.20 & 0.24 & 1.12 & 1.47 & 1.02 \\
\hline 5 & BAN & Bangladesh & 0.50 & 0.61 & 1.26 & 1.52 & 0.18 \\
\hline 6 & HKG & Hong Kong, China & 0.29 & 0.37 & 1.31 & 1.71 & 0.45 \\
\hline 7 & MAL & Malaysia & 0.23 & 0.28 & 1.36 & 1.71 & 0.53 \\
\hline 8 & INO & Indonesia & 0.27 & 0.37 & 1.49 & 1.80 & 0.29 \\
\hline 9 & $\mathrm{BHU}$ & Bhutan & 0.55 & 0.91 & 1.79 & 1.87 & 0.29 \\
\hline 10 & NEP & Nepal & 0.10 & 0.19 & 1.50 & 1.97 & 0.21 \\
\hline 11 & VAN & Vanuatu & 1.44 & 1.64 & 1.74 & 1.97 & 0.69 \\
\hline 12 & FSM & Federated States of Micronesia & 1.10 & 1.37 & 2.17 & 2.26 & -5.57 \\
\hline 13 & PRC & People's Republic of China & 0.33 & 0.46 & 1.87 & 2.51 & 0.68 \\
\hline 14 & PAK & Pakistan & 0.02 & 0.06 & 2.11 & 2.56 & 0.51 \\
\hline 15 & FIJ & Fiji & 1.12 & 1.54 & 2.02 & 2.57 & 0.61 \\
\hline 16 & THA & Thailand & 0.32 & 0.53 & 1.97 & 2.63 & 1.01 \\
\hline 17 & SIN & Singapore & 0.55 & 0.64 & 2.25 & 2.65 & 0.99 \\
\hline 18 & $\mathrm{PHI}$ & Philippines & 0.35 & 0.50 & 2.15 & 2.81 & 0.59 \\
\hline 19 & IND & India & 1.51 & 2.14 & 2.05 & 2.85 & 0.28 \\
\hline 20 & TON & Tonga & 1.52 & 1.90 & 2.19 & 2.89 & 0.91 \\
\hline 21 & PAL & Palau & 1.73 & 1.96 & 2.18 & 2.94 & 4.51 \\
\hline 22 & RMI & Marshall Islands & 1.37 & 2.09 & 2.93 & 2.99 & -2.15 \\
\hline 23 & UZB & Uzbekistan & 1.96 & 2.08 & 2.69 & 3.10 & 0.20 \\
\hline 24 & ARM & Armenia & 1.27 & 1.56 & 2.64 & 3.12 & 0.67 \\
\hline 25 & PNG & Papua New Guinea & 1.44 & 2.02 & 2.30 & 3.31 & 0.49 \\
\hline 26 & MYA & Myanmar & 2.33 & 2.76 & 2.55 & 3.35 & 0.47 \\
\hline 27 & SAM & Samoa & 0.97 & 1.76 & 3.09 & 3.45 & 1.28 \\
\hline 28 & SOL & Solomon Islands & 1.44 & 1.88 & 2.63 & 3.91 & 0.83 \\
\hline 29 & GEO & Georgia & 1.31 & 1.55 & 3.04 & 3.95 & 1.06 \\
\hline 30 & KAZ & Kazakhstan & 1.00 & 1.31 & 3.08 & 4.10 & 0.45 \\
\hline 31 & LAO & Lao People's Democratic Republic & 0.78 & 1.09 & 2.80 & 4.24 & 0.53 \\
\hline 32 & TKM & Turkmenistan & 2.78 & 4.91 & 2.96 & 4.42 & 0.71 \\
\hline 33 & MLD & Maldives & 1.34 & 1.69 & 4.06 & 4.79 & 0.74 \\
\hline 34 & TAJ & Tajikistan & 2.18 & 2.78 & 3.89 & 5.04 & 0.58 \\
\hline 35 & KIR & Kiribati & 2.88 & 4.36 & 3.81 & 5.11 & 2.95 \\
\hline 36 & TIM & Timor-Leste & 1.76 & 1.99 & 5.34 & 5.81 & 1.02 \\
\hline 37 & SRI & Sri Lanka & 0.98 & 1.12 & 4.49 & 6.77 & 0.82 \\
\hline 38 & MON & Mongolia & 1.85 & 2.30 & 5.27 & 7.18 & 0.66 \\
\hline 39 & AZE & Azerbaijan & 2.38 & 2.92 & 5.87 & 7.25 & 0.95 \\
\hline 40 & VIE & Viet Nam & 0.42 & 0.70 & 5.25 & 7.40 & 0.78 \\
\hline 41 & $K G Z$ & Kyrgyz Republic & 2.60 & 3.31 & 6.05 & 8.08 & 0.77 \\
\hline 42 & CAM & Cambodia & 0.46 & 0.75 & 4.88 & 8.56 & 1.33 \\
\hline 43 & AFG & Afghanistan & 3.35 & 4.00 & 7.37 & 10.72 & 1.48 \\
\hline
\end{tabular}

$\mathrm{ADOU}=$ Asian Development Outlook Update, $\mathrm{CoV}=$ coefficient of variation, $\mathrm{CPI}=$ Consumer Price Index, ISO = International Organization for Standardization, MAE = mean absolute error, RMSE = root mean squared error

Source: Author's calculations. 
Table A1.8: WEOU CPI Average Forecast Errors by Descending Degree of Accuracy on RMSE1

\begin{tabular}{|c|c|c|c|c|c|c|c|}
\hline \multirow[b]{2}{*}{ Rank } & \multirow[b]{2}{*}{ ISO } & \multirow[b]{2}{*}{ Economy } & \multicolumn{2}{|c|}{ Current Year } & \multicolumn{2}{|c|}{ Year Ahead } & \multirow[b]{2}{*}{$\mathrm{CoV}$} \\
\hline & & & MAEO & RMSEO & MAE1 & RMSE1 & \\
\hline 1 & TUV & Tuvalu & 0.65 & 0.87 & 0.55 & 0.69 & 0.35 \\
\hline 2 & BRU & Brunei Darussalam & 0.68 & 0.76 & 0.84 & 1.00 & 2.52 \\
\hline 3 & KOR & Republic of Korea & 0.15 & 0.21 & 1.06 & 1.19 & 0.56 \\
\hline 4 & TAP & Taipei,China & 0.43 & 0.46 & 1.11 & 1.53 & 1.02 \\
\hline 5 & VAN & Vanuatu & 0.91 & 0.98 & 1.46 & 1.60 & 0.69 \\
\hline 6 & HKG & Hong Kong, China & 0.43 & 0.61 & 1.34 & 1.67 & 0.45 \\
\hline 7 & MAL & Malaysia & 0.28 & 0.37 & 1.47 & 1.89 & 0.53 \\
\hline 8 & INO & Indonesia & 0.25 & 0.36 & 1.60 & 2.04 & 0.29 \\
\hline 9 & UZB & Uzbekistan & 0.86 & 1.04 & 1.78 & 2.05 & 0.20 \\
\hline 10 & THA & Thailand & 0.17 & 0.20 & 1.66 & 2.09 & 1.01 \\
\hline 11 & BAN & Bangladesh & 0.67 & 0.79 & 1.80 & 2.12 & 0.18 \\
\hline 12 & IND & India & 1.48 & 1.68 & 1.82 & 2.19 & 0.28 \\
\hline 13 & NEP & Nepal & 0.16 & 0.31 & 1.87 & 2.24 & 0.21 \\
\hline 14 & PRC & People's Republic of China & 0.27 & 0.32 & 1.84 & 2.31 & 0.68 \\
\hline 15 & FIJ & Fiji & 1.12 & 1.41 & 2.04 & 2.37 & 0.61 \\
\hline 16 & PAL & Palau & 1.78 & 2.25 & 2.22 & 2.41 & 4.51 \\
\hline 17 & $\mathrm{PHI}$ & Philippines & 0.38 & 0.43 & 1.93 & 2.46 & 0.59 \\
\hline 18 & SIN & Singapore & 0.40 & 0.61 & 2.25 & 2.52 & 0.99 \\
\hline 19 & PAK & Pakistan & 0.02 & 0.06 & 2.16 & 2.59 & 0.51 \\
\hline 20 & ARM & Armenia & 0.69 & 0.79 & 2.15 & 2.70 & 0.67 \\
\hline 21 & RMI & Marshall Islands & 1.43 & 1.60 & 2.43 & 2.76 & -2.15 \\
\hline 22 & $\mathrm{BHU}$ & Bhutan & 1.15 & 1.38 & 2.41 & 2.85 & 0.29 \\
\hline 23 & LAO & Lao People's Democratic Republic & 1.27 & 1.86 & 2.36 & 2.87 & 0.53 \\
\hline 24 & FSM & Federated States of Micronesia & 1.57 & 1.90 & 2.80 & 2.88 & -5.57 \\
\hline 25 & PNG & Papua New Guinea & 1.57 & 2.48 & 2.35 & 3.10 & 0.49 \\
\hline 26 & MLD & Maldives & 0.92 & 1.24 & 2.65 & 3.30 & 0.74 \\
\hline 27 & SAM & Samoa & 0.74 & 1.35 & 2.89 & 3.51 & 1.28 \\
\hline 28 & MYA & Myanmar & 1.73 & 2.08 & 2.82 & 3.55 & 0.47 \\
\hline 29 & GEO & Georgia & 0.77 & 0.89 & 3.11 & 3.76 & 1.06 \\
\hline 30 & KAZ & Kazakhstan & 0.62 & 0.90 & 2.77 & 3.90 & 0.45 \\
\hline 31 & SOL & Solomon Islands & 1.69 & 2.01 & 2.97 & 4.11 & 0.83 \\
\hline 32 & TON & Tonga & 1.97 & 2.96 & 3.67 & 4.30 & 0.91 \\
\hline 33 & KIR & Kiribati & 2.41 & 3.19 & 3.71 & 4.54 & 2.95 \\
\hline 34 & TKM & Turkmenistan & 1.00 & 1.09 & 2.91 & 4.93 & 0.71 \\
\hline 35 & TIM & Timor-Leste & 1.76 & 2.14 & 4.41 & 5.22 & 1.02 \\
\hline 36 & TAJ & Tajikistan & 1.65 & 2.26 & 4.72 & 5.37 & 0.58 \\
\hline 37 & VIE & Viet Nam & 0.97 & 1.13 & 4.85 & 6.82 & 0.78 \\
\hline 38 & CAM & Cambodia & 0.80 & 1.61 & 3.96 & 7.03 & 1.33 \\
\hline 39 & SRI & Sri Lanka & 0.79 & 0.91 & 5.42 & 7.43 & 0.82 \\
\hline 40 & AZE & Azerbaijan & 1.18 & 1.35 & 5.77 & 7.67 & 0.95 \\
\hline 41 & KGZ & Kyrgyz Republic & 1.50 & 1.88 & 6.13 & 7.87 & 0.77 \\
\hline 42 & MON & Mongolia & 1.22 & 1.41 & 5.97 & 8.24 & 0.66 \\
\hline 43 & AFG & Afghanistan & 2.44 & 3.24 & 6.64 & 9.92 & 1.48 \\
\hline
\end{tabular}

$\mathrm{CoV}=$ coefficient of variation, $\mathrm{CPI}=$ Consumer Price Index, ISO = International Organization for Standardization, $\mathrm{MAE}=$ mean absolute error, RMSE = root mean squared error WEOU = World Economic Outlook Update.

Source: Author's calculations. 
Appendix 2: G3 Growth Forecast Errors, 2007-2016

Table A2.1: ADO GDP Average Forecast Errors by Descending Degree of Accuracy on RMSE1

\begin{tabular}{lllccccc}
\hline & & \multicolumn{2}{c}{ Current } & \multicolumn{3}{c}{ Year } & \multicolumn{3}{c}{ Ahead } \\
\cline { 4 - 7 } Rank & ISO & Economy & MAE0 & RMSE0 & MAE1 & RMSE1 & CoV \\
\hline 1 & USA & United States & 0.62 & 0.69 & 1.29 & 1.85 & 1.03 \\
2 & EUA & Euro area & 0.49 & 0.65 & 1.41 & 2.19 & 3.22 \\
3 & JPN & Japan & 1.17 & 1.51 & 1.83 & 2.66 & 5.64 \\
\hline
\end{tabular}

$\mathrm{ADO}=$ Asian Development Outlook, $\mathrm{CoV}=$ coefficient of variation, GDP = gross domestic product, ISO = International Organization for Standardization, $\mathrm{MAE}=$ mean absolute error, $\mathrm{RMSE}=$ root mean squared error.

Source: Author's calculations.

Table A2.2: WEO GDP Average Forecast Errors by Descending Degree of Accuracy on RMSE1

\begin{tabular}{lllccccc}
\hline & & \multicolumn{2}{c}{ Current Year } & \multicolumn{3}{c}{ Year Ahead } \\
\cline { 4 - 6 } Rank & ISO & Economy & MAE0 & RMSE0 & MAE1 & RMSE1 & CoV \\
\hline 1 & USA & United States & 0.44 & 0.54 & 1.36 & 1.75 & 1.03 \\
2 & EUA & Euro area & 0.33 & 0.40 & 1.38 & 2.07 & 3.22 \\
3 & JPN & Japan & 1.01 & 1.32 & 1.80 & 2.73 & 5.64 \\
\hline
\end{tabular}

$\mathrm{CoV}=$ coefficient of variation, GDP = gross domestic product, ISO = International Organization for Standardization, MAE = mean absolute error, RMSE = root mean squared error, WEO = World Economic Outlook.

Source: Author's calculations.

Table A2.3: ADOU GDP Average Forecast Errors by Descending Degree of Accuracy on RMSE1

\begin{tabular}{lllccccc}
\hline & & & \multicolumn{2}{c}{ Current Year } & \multicolumn{2}{c}{ Year Ahead } & \\
\cline { 4 - 6 } Rank & ISO & Economy & MAEO & RMSE0 & MAE1 & RMSE1 & CoV \\
\hline 1 & USA & United States & 0.33 & 0.46 & 1.13 & 1.53 & 1.03 \\
2 & EUA & Euro area & 0.24 & 0.32 & 1.34 & 2.00 & 3.22 \\
3 & JPN & Japan & 0.65 & 0.85 & 1.82 & 2.53 & 5.64 \\
\hline
\end{tabular}

ADOU = Asian Development Outlook Update, $\mathrm{CoV}=$ coefficient of variation, GDP = gross domestic product, ISO = International Organization for Standardization, $\mathrm{MAE}=$ mean absolute error, $\mathrm{RMSE}=$ root mean squared error

Source: Author's calculations.

Table A2.4: WEOU GDP Average Forecast Errors by Descending Degree of Accuracy on RMSE1

\begin{tabular}{lllccccc}
\hline & & & \multicolumn{2}{c}{ Current Year } & \multicolumn{2}{c}{ Year Ahead } & \\
\cline { 4 - 6 } Rank & ISO & Economy & MAEO & RMSEO & MAE1 & RMSE1 & CoV \\
\hline 1 & USA & United States & 0.36 & 0.50 & 1.02 & 1.26 & 1.03 \\
2 & EUA & Euro area & 0.17 & 0.24 & 1.09 & 1.62 & 3.22 \\
3 & JPN & Japan & 0.55 & 0.71 & 1.49 & 2.25 & 5.64 \\
\hline
\end{tabular}

$\mathrm{CoV}=$ coefficient of variation, GDP = gross domestic product, ISO = International Organization for Standardization, MAE = mean absolute error, $\mathrm{RMSE}=$ root mean squared error, $\mathrm{WEOU}=$ World Economic Outlook Update.

Source: Author's calculations. 
Appendix 3: Growth and Inflation Count Scores

Table A3.1: Gross Domestic Product Growth

\begin{tabular}{|c|c|c|c|c|}
\hline & \multicolumn{2}{|c|}{ Estimates } & \multicolumn{2}{|c|}{ Forecasts } \\
\hline & ADO & ADOU & ADO & ADOU \\
\hline Afghanistan & -0.3 & 0.2 & 0.5 & -0.1 \\
\hline Armenia & -0.4 & -0.3 & -0.3 & 0.0 \\
\hline Azerbaijan & -0.3 & 0.2 & -0.2 & 0.2 \\
\hline Bangladesh & 0.3 & 0.3 & -0.3 & -0.8 \\
\hline Bhutan & 0.0 & 0.6 & 0.4 & 0.2 \\
\hline Brunei Darussalam & 0.1 & 0.1 & 0.7 & 0.7 \\
\hline Cambodia & 0.0 & 0.4 & 0.0 & -0.4 \\
\hline Fiji & 0.0 & -0.2 & 0.0 & 0.0 \\
\hline Georgia & 0.0 & 0.1 & 0.1 & -0.1 \\
\hline Hong Kong, China & 0.1 & 0.2 & 0.1 & -0.5 \\
\hline India & -0.3 & 0.0 & -0.4 & -0.4 \\
\hline Indonesia & -0.5 & 0.4 & -0.4 & -0.5 \\
\hline Kazakhstan & 0.3 & -0.2 & -0.2 & -0.3 \\
\hline Kiribati & 0.0 & -0.4 & 0.3 & 0.1 \\
\hline Republic of Korea & 0.0 & -0.6 & 0.0 & 0.0 \\
\hline Kyrgyz Republic & -0.5 & -0.1 & -0.2 & 0.4 \\
\hline Lao People's Democratic Republic & 0.3 & 0.1 & 0.9 & -0.1 \\
\hline Malaysia & -0.2 & 0.1 & 0.0 & -0.3 \\
\hline Maldives & -0.5 & 0.0 & -0.3 & -0.2 \\
\hline Marshall Islands & -0.3 & -0.3 & 0.3 & 0.3 \\
\hline Federated States of Micronesia & -0.3 & 0.3 & -1.0 & -1.0 \\
\hline Mongolia & 0.0 & -0.1 & -0.5 & 0.4 \\
\hline Myanmar & 0.2 & 0.0 & 0.7 & 0.3 \\
\hline Nepal & 0.3 & 0.0 & -0.4 & 0.2 \\
\hline People's Republic of China & -0.4 & -0.3 & 0.2 & -0.4 \\
\hline Pakistan & 0.0 & -0.1 & 0.2 & 0.0 \\
\hline Palau & 0.0 & 1.0 & -1.0 & -1.0 \\
\hline Papua New Guinea & 0.3 & 0.1 & 0.2 & 0.2 \\
\hline Philippines & 0.1 & 0.0 & 0.1 & -0.1 \\
\hline Samoa & 0.7 & 0.3 & 0.1 & -0.1 \\
\hline Singapore & 0.1 & -0.4 & 0.0 & -0.2 \\
\hline Solomon Islands & 0.5 & 0.4 & 0.1 & 0.0 \\
\hline Sri Lanka & 0.2 & 0.2 & -0.4 & -0.3 \\
\hline Taipei,China & 0.0 & -0.4 & 0.3 & -0.2 \\
\hline Tajikistan & 0.2 & -0.2 & 0.1 & 0.2 \\
\hline Thailand & 0.0 & -0.4 & 0.0 & -0.4 \\
\hline Timor-Leste & 0.3 & -0.1 & 0.2 & -0.3 \\
\hline Tonga & 0.3 & 0.3 & 0.1 & -0.1 \\
\hline Turkmenistan & 0.0 & 0.1 & 0.3 & 0.1 \\
\hline Tuvalu & 0.4 & 0.2 & 0.0 & 0.0 \\
\hline Uzbekistan & 0.5 & 0.6 & 0.4 & 0.5 \\
\hline Vanuatu & -0.1 & -0.1 & 0.4 & 0.4 \\
\hline Viet Nam & 0.4 & -0.1 & 0.4 & 0.0 \\
\hline
\end{tabular}

ADO = Asian Development Outlook, ADOU = Asian Development Outlook Update.

Source: Author's calculations. 
Table A3.2: Inflation (Consumer Price Index)

\begin{tabular}{|c|c|c|c|c|}
\hline & \multicolumn{2}{|c|}{ Estimates } & \multicolumn{2}{|c|}{ Forecasts } \\
\hline & ADO & ADOU & ADO & ADOU \\
\hline Afghanistan & -0.3 & -0.6 & 0.3 & -0.5 \\
\hline Armenia & -0.3 & -0.3 & -0.1 & -0.4 \\
\hline Azerbaijan & 0.0 & -0.6 & -0.3 & -0.1 \\
\hline Bangladesh & 0.1 & 0.2 & 0.8 & 0.8 \\
\hline Bhutan & 0.1 & 0.7 & 0.0 & 0.5 \\
\hline Brunei Darussalam & 0.4 & 0.6 & -0.6 & 0.0 \\
\hline Cambodia & 0.2 & 0.1 & 0.1 & -0.4 \\
\hline Fiji & -0.5 & 0.1 & -0.2 & -0.1 \\
\hline Georgia & -0.1 & -0.4 & 0.3 & -0.4 \\
\hline Hong Kong, China & -0.4 & 0.1 & 0.4 & -0.2 \\
\hline India & 0.0 & 0.4 & 0.4 & 0.1 \\
\hline Indonesia & -0.6 & 0.1 & -0.4 & 0.0 \\
\hline Kazakhstan & -0.3 & -0.4 & 0.2 & -0.4 \\
\hline Kiribati & 0.0 & 0.1 & 0.4 & -0.1 \\
\hline Republic of Korea & -0.1 & -0.2 & 0.4 & -0.4 \\
\hline Kyrgyz Republic & -0.3 & -0.2 & 0.0 & 0.0 \\
\hline Lao People's Democratic Republic & 0.3 & 0.3 & 0.3 & 0.1 \\
\hline Malaysia & 0.1 & 0.0 & 0.3 & 0.2 \\
\hline Maldives & -0.6 & -0.2 & -0.5 & -0.5 \\
\hline Marshall Islands & -0.3 & 0.3 & -0.3 & -0.3 \\
\hline Federated States of Micronesia & 0.3 & 0.3 & 0.0 & 0.3 \\
\hline Mongolia & 0.0 & -0.1 & 0.5 & 0.1 \\
\hline Myanmar & 0.2 & -0.2 & 0.5 & 0.3 \\
\hline Nepal & -0.4 & 0.4 & 0.2 & 0.3 \\
\hline People's Republic of China & -0.8 & 0.0 & -0.1 & -0.3 \\
\hline Pakistan & -0.4 & 0.0 & 0.2 & -0.1 \\
\hline Palau & 0.0 & 0.0 & 0.0 & 0.0 \\
\hline Papua New Guinea & 0.2 & 0.0 & 0.0 & 0.1 \\
\hline Philippines & -0.5 & 0.2 & 0.0 & -0.3 \\
\hline Samoa & -0.4 & -0.3 & 0.1 & 0.0 \\
\hline Singapore & 0.2 & -0.3 & 0.0 & -0.2 \\
\hline Solomon Islands & 0.0 & 0.0 & 0.0 & 0.6 \\
\hline Sri Lanka & 0.0 & -0.3 & 0.6 & 0.3 \\
\hline Taipei,China & 0.4 & 0.8 & -0.3 & -0.2 \\
\hline Tajikistan & -0.2 & 0.0 & 0.0 & 0.5 \\
\hline Thailand & -0.2 & -0.2 & 0.0 & -0.1 \\
\hline Timor-Leste & -0.2 & -0.1 & -0.3 & -0.6 \\
\hline Tonga & 0.2 & 0.0 & 0.2 & 0.4 \\
\hline Turkmenistan & -0.6 & -0.2 & -0.1 & 0.2 \\
\hline Tuvalu & 0.0 & -0.2 & -1.0 & -0.4 \\
\hline Uzbekistan & -0.5 & -0.7 & -0.6 & -0.6 \\
\hline Vanuatu & -0.7 & -0.4 & -0.4 & -0.2 \\
\hline Viet Nam & 0.5 & 0.8 & -0.6 & -0.2 \\
\hline
\end{tabular}

ADO = Asian Development Outlook, ADOU = Asian Development Outlook Update. Source: Author's calculations. 
Table A3.3: Asia-43 Average Count Scores by Years-Growth and Inflation

\begin{tabular}{lcccc|crrr}
\hline & \multicolumn{4}{c}{ GDP Growth } & \multicolumn{4}{c}{ CPI Inflation } \\
\cline { 2 - 9 } Year & \multicolumn{2}{c}{ Estimates } & \multicolumn{2}{c|}{ Forecasts } & \multicolumn{2}{c}{ Estimates } & \multicolumn{2}{c}{ Forecasts } \\
\cline { 2 - 8 } & ADO & ADOU & ADO & ADOU & ADO & ADOU & ADO & ADOU \\
\hline 2007 & 0.0 & -0.2 & 0.1 & -0.2 & -0.1 & 0.0 & -0.2 & -0.4 \\
2008 & -0.0 & -0.1 & -0.2 & -0.4 & -0.3 & -0.2 & 0.0 & -0.3 \\
2009 & 0.3 & 0.1 & -0.2 & -0.2 & -0.5 & -0.0 & -0.1 & 0.2 \\
2010 & -0.0 & -0.1 & 0.5 & 0.3 & -0.0 & -0.1 & 0.3 & 0.1 \\
2011 & 0.2 & 0.1 & -0.1 & -0.1 & 0.0 & 0.2 & 0.1 & -0.2 \\
2012 & 0.1 & 0.1 & 0.3 & -0.1 & -0.4 & -0.2 & 0.2 & -0.1 \\
2013 & -0.2 & 0.1 & -0.1 & 0.2 & 0.0 & 0.2 & -0.1 & -0.1 \\
2014 & 0.0 & -0.1 & 0.4 & -0.0 & -0.1 & -0.2 & 0.1 & 0.2 \\
2015 & 0.1 & 0.2 & -0.0 & -0.1 & -0.0 & -0.0 & -0.1 & 0.0 \\
2016 & -0.1 & 0.2 & -0.1 & -0.1 & -0.0 & 0.2 & -0.1 & 0.0 \\
\hline
\end{tabular}

$\mathrm{ADO}=$ Asian Development Outlook, $\mathrm{ADOU}=$ Asian Development Outlook Update, $\mathrm{CPI}=$ Consumer Price Index, GDP = gross domestic product.

Source: Author's calculations.

Table A3.4: Asia-11 Average Count Scores by Years-Growth and Inflation

\begin{tabular}{ccccc|cccc}
\hline & \multicolumn{4}{c}{ GDP Growth } & \multicolumn{4}{c}{ CPI Inflation } \\
\cline { 2 - 9 } Year & \multicolumn{2}{c}{ Estimates } & \multicolumn{2}{c|}{ Forecasts } & \multicolumn{2}{c}{ Estimates } & \multicolumn{2}{c}{ Forecasts } \\
\cline { 2 - 8 } & ADO & ADOU & \multicolumn{1}{c}{ ADO } & ADOU & ADO & ADOU & ADO & ADOU \\
\hline 2007 & -0.1 & -0.1 & 0.1 & -0.2 & -0.2 & 0.1 & -0.5 & -0.8 \\
2008 & -0.6 & -0.6 & -0.4 & -1.0 & 0.0 & -0.2 & 0.3 & -0.4 \\
2009 & 0.8 & -0.1 & -0.5 & -1.0 & -0.5 & 0.5 & -0.4 & -0.2 \\
2010 & 0.1 & -0.4 & 1.0 & 0.1 & -0.1 & 0.3 & -0.1 & 0.0 \\
2011 & 0.2 & -0.2 & -0.1 & -0.1 & -0.3 & 0.5 & 0.3 & -0.3 \\
2012 & -0.4 & 0.1 & 0.1 & -0.6 & 0.2 & 0.2 & -0.3 & -0.3 \\
2013 & -0.4 & -0.3 & 0.0 & 0.3 & 0.0 & 0.3 & -0.1 & 0.1 \\
2014 & -0.2 & -0.5 & 0.5 & 0.3 & 0.1 & -0.4 & 0.5 & 0.4 \\
2015 & -0.1 & 0.5 & -0.3 & -0.1 & -0.2 & 0.1 & 0.0 & 0.0 \\
2016 & 0.0 & 0.2 & -0.2 & -0.4 & -0.3 & 0.2 & 0.4 & 0.0 \\
\hline
\end{tabular}

$\mathrm{ADO}=$ Asian Development Outlook, $\mathrm{ADOU}=$ Asian Development Outlook Update, $\mathrm{CPI}=$ Consumer Price Index, GDP = gross domestic product.

Source: Author's calculations. 
Appendix 4: Asia-43-Gross Domestic Product Forecast Optimism, 2011-2016

Table A4.1: Asian Development Outlook Optimism

\begin{tabular}{|c|c|c|c|c|c|c|}
\hline \multirow[b]{2}{*}{ Rank } & \multirow[b]{2}{*}{ ISO } & \multirow[b]{2}{*}{ Economy } & \multicolumn{2}{|c|}{ Current Year } & \multicolumn{2}{|c|}{ Year Ahead } \\
\hline & & & Size & Count & Size & Count \\
\hline 1 & AZE & Azerbaijan & -1.92 & 0.83 & -3.82 & 0.83 \\
\hline 2 & BRU & Brunei Darussalam & -1.80 & 0.67 & -2.43 & 0.83 \\
\hline 3 & FSM & Federated States of Micronesia & -1.72 & 1.00 & -2.32 & 0.67 \\
\hline 4 & THA & Thailand & -1.33 & 0.67 & -2.00 & 0.83 \\
\hline 5 & TAP & Taipei,China & -1.07 & 0.83 & -1.83 & 1.00 \\
\hline 6 & VAN & Vanuatu & -0.67 & 0.83 & -1.83 & 1.00 \\
\hline 7 & PNG & Papua New Guinea & -0.79 & 0.50 & -1.44 & 0.33 \\
\hline 8 & $\mathrm{SIN}$ & Singapore & -0.47 & 0.80 & -1.42 & 1.00 \\
\hline 9 & $\mathrm{BHU}$ & Bhutan & -1.08 & 0.83 & -1.42 & 0.67 \\
\hline 10 & MON & Mongolia & -0.26 & 0.67 & -1.41 & 0.67 \\
\hline 11 & TIM & Timor-Leste & -1.26 & 0.67 & -1.41 & 0.83 \\
\hline 12 & AFG & Afghanistan & -0.08 & 0.50 & -1.38 & 0.83 \\
\hline 13 & IND & India & -0.72 & 0.83 & -1.35 & 0.67 \\
\hline 14 & SRI & Sri Lanka & -0.77 & 0.67 & -1.33 & 0.83 \\
\hline 15 & HKG & Hong Kong, China & -0.61 & 1.00 & -1.26 & 0.83 \\
\hline 16 & KAZ & Kazakhstan & -0.19 & 0.50 & -1.24 & 0.83 \\
\hline 17 & KOR & Republic of Korea & -0.55 & 0.67 & -1.18 & 1.00 \\
\hline 18 & NEP & Nepal & -0.37 & 0.33 & -1.05 & 0.67 \\
\hline 19 & INO & Indonesia & -0.38 & 0.83 & -0.78 & 0.83 \\
\hline 20 & MLD & Maldives & -0.45 & 0.50 & -0.77 & 0.67 \\
\hline 21 & PRC & People's Republic of China & -0.33 & 0.83 & -0.64 & 0.83 \\
\hline 22 & GEO & Georgia & -0.07 & 0.33 & -0.53 & 0.50 \\
\hline 23 & KGZ & Kyrgyz Republic & 0.25 & 0.33 & -0.38 & 0.67 \\
\hline 24 & RMI & Marshall Islands & -1.53 & 0.67 & -0.37 & 0.67 \\
\hline 25 & VIE & Viet Nam & 0.00 & 0.50 & -0.32 & 0.60 \\
\hline 26 & ARM & Armenia & 0.25 & 0.50 & -0.27 & 0.67 \\
\hline 27 & SAM & Samoa & 0.28 & 0.83 & -0.08 & 0.67 \\
\hline 28 & MAL & Malaysia & 0.33 & 0.40 & -0.03 & 0.40 \\
\hline 29 & LAO & Lao People's Democratic Republic & 0.15 & 0.00 & -0.02 & 0.50 \\
\hline 30 & PAK & Pakistan & 0.31 & 0.20 & 0.01 & 0.40 \\
\hline 31 & UZB & Uzbekistan & 0.42 & 0.17 & 0.02 & 0.33 \\
\hline 32 & CAM & Cambodia & 0.21 & 0.20 & 0.11 & 0.50 \\
\hline 33 & MYA & Myanmar & -0.25 & 0.40 & 0.17 & 0.40 \\
\hline 34 & BAN & Bangladesh & 0.37 & 0.17 & 0.21 & 0.17 \\
\hline 35 & TKM & Turkmenistan & 0.63 & 0.50 & 0.30 & 0.33 \\
\hline 36 & SOL & Solomon Islands & -0.17 & 0.50 & 0.49 & 0.50 \\
\hline 37 & $\mathrm{PHI}$ & Philippines & 0.37 & 0.50 & 0.50 & 0.33 \\
\hline 38 & TUV & Tuvalu & 0.09 & 0.33 & 0.67 & 0.00 \\
\hline 39 & $\mathrm{KIR}$ & Kiribati & 0.44 & 0.33 & 0.79 & 0.17 \\
\hline 40 & TON & Tonga & 0.83 & 0.00 & 0.83 & 0.17 \\
\hline 41 & FIJ & Fiji & 0.95 & 0.17 & 1.15 & 0.17 \\
\hline 42 & TAJ & Tajikistan & 1.55 & 0.00 & 1.22 & 0.00 \\
\hline \multirow[t]{2}{*}{43} & PAL & Palau & 0.15 & 0.50 & 1.65 & 0.50 \\
\hline & Average & Asia-43 & -0.24 & 0.52 & -0.63 & 0.59 \\
\hline
\end{tabular}

ISO = International Organization for Standardization.

Source: Author's calculations. 
Table A4.2: Asian Development Outlook Update Optimism

\begin{tabular}{|c|c|c|c|c|c|c|}
\hline \multirow[b]{2}{*}{ Rank } & \multirow[b]{2}{*}{ ISO } & \multirow[b]{2}{*}{ Economy } & \multicolumn{2}{|c|}{ Current Year } & \multicolumn{2}{|c|}{ Year Ahead } \\
\hline & & & Size & Count & Size & Count \\
\hline 1 & AZE & Azerbaijan & -1.17 & 0.83 & -2.57 & 0.83 \\
\hline 2 & BRU & Brunei Darussalam & -1.57 & 0.67 & -2.23 & 0.83 \\
\hline 3 & FSM & Federated States of Micronesia & -0.78 & 0.67 & -1.95 & 0.67 \\
\hline 4 & VAN & Vanuatu & -0.30 & 0.67 & -1.83 & 1.00 \\
\hline 5 & THA & Thailand & -0.68 & 0.60 & -1.80 & 0.83 \\
\hline 6 & $\mathrm{BHU}$ & Bhutan & -1.10 & 0.83 & -1.48 & 0.83 \\
\hline 7 & TAP & Taipei,China & -0.23 & 0.67 & -1.45 & 0.80 \\
\hline 8 & TIM & Timor-Leste & -1.17 & 0.67 & -1.44 & 0.83 \\
\hline 9 & KAZ & Kazakhstan & 0.33 & 0.50 & -1.21 & 0.83 \\
\hline 10 & AFG & Afghanistan & 0.20 & 0.67 & -1.20 & 0.83 \\
\hline 11 & SRI & Sri Lanka & -0.52 & 0.67 & -1.12 & 0.67 \\
\hline 12 & PNG & Papua New Guinea & 0.56 & 0.40 & -1.11 & 0.33 \\
\hline 13 & SIN & Singapore & -0.12 & 0.67 & -1.08 & 0.83 \\
\hline 14 & HKG & Hong Kong, China & -0.08 & 0.75 & -1.06 & 0.83 \\
\hline 15 & KOR & Republic of Korea & -0.25 & 0.67 & -1.00 & 1.00 \\
\hline 16 & IND & India & -0.15 & 0.50 & -0.98 & 0.67 \\
\hline 17 & NEP & Nepal & -0.08 & 0.33 & -0.92 & 0.67 \\
\hline 18 & MLD & Maldives & -0.63 & 0.67 & -0.82 & 0.67 \\
\hline 19 & INO & Indonesia & -0.08 & 0.80 & -0.60 & 0.83 \\
\hline 20 & KGZ & Kyrgyz Republic & 1.08 & 0.33 & -0.47 & 0.67 \\
\hline 21 & GEO & Georgia & 0.27 & 0.33 & -0.45 & 0.50 \\
\hline 22 & PRC & People's Republic of China & 0.01 & 0.40 & -0.38 & 0.80 \\
\hline 23 & ARM & Armenia & 0.37 & 0.50 & -0.37 & 0.67 \\
\hline 24 & RMI & Marshall Islands & -1.53 & 0.67 & -0.37 & 0.67 \\
\hline 25 & VIE & Viet Nam & 0.22 & 0.00 & -0.27 & 0.67 \\
\hline 26 & SAM & Samoa & -0.01 & 0.67 & -0.04 & 0.67 \\
\hline 27 & LAO & Lao People's Democratic Republic & 0.15 & 0.20 & 0.07 & 0.50 \\
\hline 28 & MAL & Malaysia & 0.40 & 0.00 & 0.08 & 0.50 \\
\hline 29 & MON & Mongolia & 1.49 & 0.17 & 0.09 & 0.67 \\
\hline 30 & BAN & Bangladesh & 0.02 & 0.33 & 0.11 & 0.17 \\
\hline 31 & UZB & Uzbekistan & 0.48 & 0.17 & 0.13 & 0.33 \\
\hline 32 & PAL & Palau & -0.35 & 1.00 & 0.15 & 0.50 \\
\hline 33 & MYA & Myanmar & -0.27 & 0.33 & 0.17 & 0.33 \\
\hline 34 & TKM & Turkmenistan & 1.03 & 0.33 & 0.22 & 0.33 \\
\hline 35 & CAM & Cambodia & 0.23 & 0.00 & 0.24 & 0.50 \\
\hline 36 & PAK & Pakistan & 0.16 & 0.50 & 0.34 & 0.25 \\
\hline 37 & SOL & Solomon Islands & 0.79 & 0.17 & 0.49 & 0.50 \\
\hline 38 & $\mathrm{PHI}$ & Philippines & 0.17 & 0.50 & 0.55 & 0.40 \\
\hline 39 & TUV & Tuvalu & 0.23 & 0.25 & 0.65 & 0.00 \\
\hline 40 & TON & Tonga & 0.63 & 0.20 & 0.68 & 0.33 \\
\hline 41 & KIR & Kiribati & 0.44 & 0.17 & 0.83 & 0.17 \\
\hline 42 & FIJ & Fiji & 0.62 & 0.17 & 0.90 & 0.17 \\
\hline \multirow[t]{2}{*}{43} & TAJ & Tajikistan & 1.38 & 0.00 & 1.23 & 0.00 \\
\hline & Average & Asia-43 & 0.04 & 0.44 & -0.49 & 0.59 \\
\hline
\end{tabular}

ISO = International Organization for Standardization. 
Table A4.3: World Economic Outlook Optimism

\begin{tabular}{|c|c|c|c|c|c|c|}
\hline \multirow[b]{2}{*}{ Rank } & \multirow[b]{2}{*}{ ISO } & \multirow[b]{2}{*}{ Economy } & \multicolumn{2}{|c|}{ Current Year } & \multicolumn{2}{|c|}{ Year Ahead } \\
\hline & & & Size & Count & Size & Count \\
\hline 1 & BRU & Brunei Darussalam & -2.42 & 1.00 & -3.52 & 0.83 \\
\hline 2 & TAP & Taipei,China & -1.18 & 0.80 & -2.22 & 1.00 \\
\hline 3 & THA & Thailand & -1.37 & 0.67 & -2.18 & 0.83 \\
\hline 4 & VAN & Vanuatu & -0.45 & 0.83 & -2.13 & 1.00 \\
\hline 5 & $\mathrm{BHU}$ & Bhutan & -0.90 & 0.67 & -1.68 & 0.67 \\
\hline 6 & TIM & Timor-Leste & -1.07 & 0.67 & -1.68 & 0.67 \\
\hline 7 & AZE & Azerbaijan & -0.68 & 0.67 & -1.57 & 0.83 \\
\hline 8 & AFG & Afghanistan & -0.18 & 0.50 & -1.43 & 0.83 \\
\hline 9 & SIN & Singapore & -0.22 & 0.67 & -1.38 & 1.00 \\
\hline 10 & HKG & Hong Kong, China & -0.57 & 1.00 & -1.31 & 0.83 \\
\hline 11 & KOR & Republic of Korea & -0.53 & 0.67 & -1.18 & 1.00 \\
\hline 12 & $K G Z$ & Kyrgyz Republic & -0.13 & 0.33 & -1.07 & 0.50 \\
\hline 13 & RMI & Marshall Islands & -1.10 & 0.67 & -1.03 & 1.00 \\
\hline 14 & IND & India & -0.60 & 0.67 & -1.00 & 0.67 \\
\hline 15 & KAZ & Kazakhstan & 0.01 & 0.50 & -0.94 & 0.80 \\
\hline 16 & NEP & Nepal & -0.25 & 0.50 & -0.82 & 0.67 \\
\hline 17 & PRC & People's Republic of China & -0.18 & 0.67 & -0.74 & 0.83 \\
\hline 18 & FSM & Federated States of Micronesia & -0.62 & 0.33 & -0.72 & 0.67 \\
\hline 19 & INO & Indonesia & -0.13 & 0.50 & -0.62 & 0.83 \\
\hline 20 & PNG & Papua New Guinea & -1.07 & 0.33 & -0.49 & 0.33 \\
\hline 21 & SRI & Sri Lanka & -0.38 & 0.67 & -0.47 & 0.67 \\
\hline 22 & GEO & Georgia & -0.07 & 0.33 & -0.28 & 0.67 \\
\hline 23 & VIE & Viet Nam & 0.07 & 0.50 & -0.15 & 0.50 \\
\hline 24 & MLD & Maldives & -0.42 & 0.50 & -0.03 & 0.50 \\
\hline 25 & SOL & Solomon Islands & -0.11 & 0.67 & -0.01 & 0.67 \\
\hline 26 & LAO & $\begin{array}{l}\text { Lao People's Democratic } \\
\text { Republic }\end{array}$ & -0.13 & 0.83 & 0.03 & 0.50 \\
\hline 27 & BAN & Bangladesh & 0.29 & 0.00 & 0.04 & 0.50 \\
\hline 28 & SAM & Samoa & 0.49 & 0.67 & 0.04 & 0.67 \\
\hline 29 & PAK & Pakistan & 0.34 & 0.20 & 0.08 & 0.33 \\
\hline 30 & MAL & Malaysia & 0.20 & 0.50 & 0.08 & 0.33 \\
\hline 31 & CAM & Cambodia & 0.33 & 0.40 & 0.23 & 0.50 \\
\hline 32 & MYA & Myanmar & -0.28 & 0.40 & 0.28 & 0.33 \\
\hline 33 & ARM & Armenia & 0.68 & 0.50 & 0.35 & 0.50 \\
\hline 34 & TON & Tonga & 0.28 & 0.33 & 0.37 & 0.33 \\
\hline 35 & MON & Mongolia & -1.03 & 0.67 & 0.51 & 0.67 \\
\hline 36 & TUV & Tuvalu & -0.03 & 0.50 & 0.63 & 0.00 \\
\hline 37 & TKM & Turkmenistan & 1.88 & 0.33 & 0.68 & 0.33 \\
\hline 38 & $\mathrm{KIR}$ & Kiribati & 0.28 & 0.17 & 0.79 & 0.33 \\
\hline 39 & $\mathrm{PHI}$ & Philippines & 0.40 & 0.50 & 0.80 & 0.33 \\
\hline 40 & FIJ & Fiji & 0.93 & 0.17 & 1.02 & 0.33 \\
\hline 41 & UZB & Uzbekistan & 1.53 & 0.00 & 1.40 & 0.00 \\
\hline 42 & TAJ & Tajikistan & 1.82 & 0.00 & 1.67 & 0.00 \\
\hline \multirow[t]{2}{*}{43} & PAL & Palau & 3.55 & 0.50 & 3.20 & 0.50 \\
\hline & Average & Asia-43 & -0.11 & 0.50 & -0.46 & 0.59 \\
\hline
\end{tabular}

ISO = International Organization for Standardization. Source: Author's calculations. 
Table A4.4: World Economic Outlook Update Optimism

\begin{tabular}{|c|c|c|c|c|c|c|}
\hline \multirow[b]{2}{*}{ Rank } & \multirow[b]{2}{*}{ ISO } & \multirow[b]{2}{*}{ Economy } & \multicolumn{2}{|c|}{ Current Year } & \multicolumn{2}{|c|}{ Year Ahead } \\
\hline & & & Size & Count & Size & Count \\
\hline 1 & BRU & Brunei Darussalam & -2.58 & 0.83 & -3.53 & 0.83 \\
\hline 2 & $\mathrm{BHU}$ & Bhutan & -1.18 & 0.83 & -2.63 & 0.83 \\
\hline 3 & AZE & Azerbaijan & -0.87 & 0.83 & -2.58 & 0.83 \\
\hline 4 & VAN & Vanuatu & -0.30 & 0.80 & -2.00 & 1.00 \\
\hline 5 & THA & Thailand & -0.42 & 0.60 & -1.90 & 0.80 \\
\hline 6 & KGZ & Kyrgyz Republic & 0.42 & 0.50 & -1.73 & 0.67 \\
\hline 7 & TAP & Taipei,China & -0.35 & 0.60 & -1.70 & 1.00 \\
\hline 8 & HKG & Hong Kong, China & -0.24 & 0.83 & -1.11 & 0.83 \\
\hline 9 & RMI & Marshall Islands & -1.07 & 0.67 & -1.03 & 1.00 \\
\hline 10 & KOR & Republic of Korea & -0.20 & 0.67 & -1.02 & 1.00 \\
\hline 11 & MON & Mongolia & 0.66 & 0.67 & -0.94 & 0.67 \\
\hline 12 & AFG & Afghanistan & 0.55 & 0.50 & -0.93 & 0.83 \\
\hline 13 & FSM & Federated States of Micronesia & -0.45 & 0.33 & -0.88 & 1.00 \\
\hline 14 & NEP & Nepal & -0.17 & 0.50 & -0.85 & 0.50 \\
\hline 15 & TIM & Timor-Leste & 0.06 & 0.67 & -0.82 & 0.50 \\
\hline 16 & $\operatorname{SIN}$ & Singapore & -0.13 & 0.67 & -0.67 & 0.67 \\
\hline 17 & KAZ & Kazakhstan & 0.48 & 0.50 & -0.59 & 0.67 \\
\hline 18 & IND & India & 0.10 & 0.50 & -0.55 & 0.67 \\
\hline 19 & SRI & Sri Lanka & -0.27 & 0.67 & -0.50 & 0.67 \\
\hline 20 & PRC & People's Republic of China & -0.03 & 0.50 & -0.33 & 0.80 \\
\hline 21 & PNG & Papua New Guinea & -0.11 & 0.67 & -0.31 & 0.33 \\
\hline 22 & LAO & Lao People's Democratic Republic & -0.33 & 1.00 & -0.28 & 0.83 \\
\hline 23 & INO & Indonesia & 0.13 & 0.17 & -0.27 & 0.83 \\
\hline 24 & ARM & Armenia & -0.00 & 0.33 & -0.23 & 0.67 \\
\hline 25 & GEO & Georgia & 0.28 & 0.50 & -0.18 & 0.67 \\
\hline 26 & VIE & Viet Nam & 0.18 & 0.00 & -0.17 & 0.67 \\
\hline 27 & SOL & Solomon Islands & 0.33 & 0.50 & -0.02 & 0.67 \\
\hline 28 & TUV & Tuvalu & -0.27 & 0.80 & 0.03 & 0.50 \\
\hline 29 & MYA & Myanmar & -0.43 & 0.60 & 0.07 & 0.33 \\
\hline 30 & MAL & Malaysia & 0.23 & 0.40 & 0.15 & 0.60 \\
\hline 31 & SAM & Samoa & 0.41 & 0.50 & 0.16 & 0.67 \\
\hline 32 & CAM & Cambodia & 0.23 & 0.25 & 0.18 & 0.50 \\
\hline 33 & TON & Tonga & 0.25 & 0.50 & 0.18 & 0.33 \\
\hline 34 & BAN & Bangladesh & 0.17 & 0.00 & 0.19 & 0.17 \\
\hline 35 & TKM & Turkmenistan & 0.82 & 0.33 & 0.30 & 0.50 \\
\hline 36 & PAK & Pakistan & 0.13 & 0.50 & 0.41 & 0.20 \\
\hline 37 & MLD & Maldives & 0.42 & 0.17 & 0.42 & 0.33 \\
\hline 38 & $\mathrm{KIR}$ & Kiribati & 0.06 & 0.40 & 0.59 & 0.17 \\
\hline 39 & $\mathrm{PHI}$ & Philippines & 0.32 & 0.50 & 0.67 & 0.33 \\
\hline 40 & FIJ & Fiji & 0.27 & 0.33 & 0.75 & 0.17 \\
\hline 41 & UZB & Uzbekistan & 1.18 & 0.00 & 1.32 & 0.00 \\
\hline 42 & TAJ & Tajikistan & 1.22 & 0.00 & 1.62 & 0.00 \\
\hline \multirow[t]{2}{*}{43} & PAL & Palau & 3.65 & 0.00 & 3.20 & 0.50 \\
\hline & Average & Asia-43 & 0.04 & 0.50 & -0.46 & 0.59 \\
\hline
\end{tabular}

ISO = International Organization for Standardization.

Source: Author's calculations. 
Appendix 5: Asia-43 Forecast Errors and Brier Scores by Years

Figure A5.1: Asia-43 Gross Domestic Product Growth, Current Year and Year Ahead
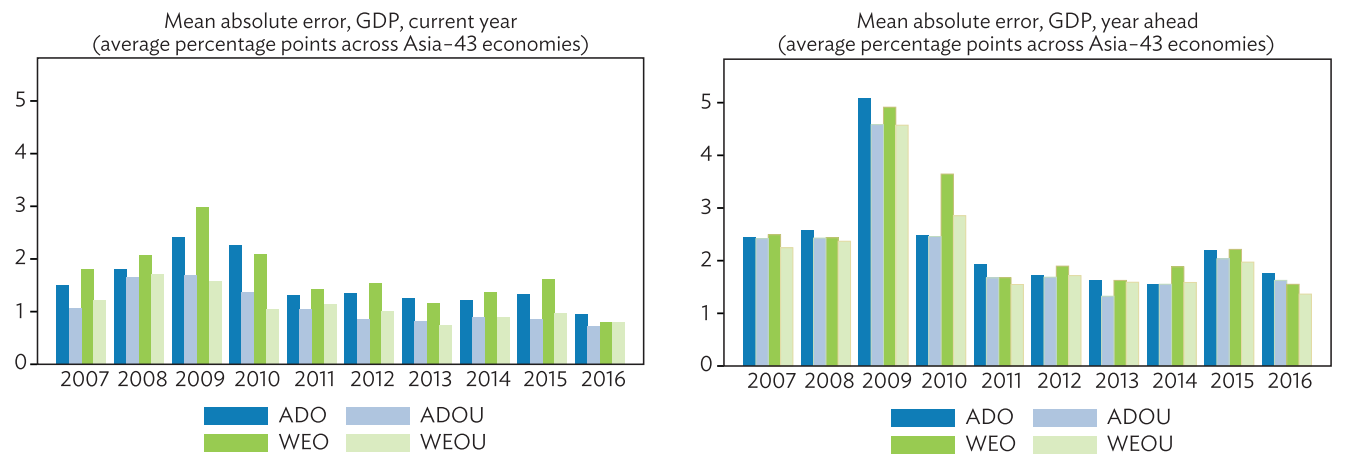

Root mean squared error, GDP, current year
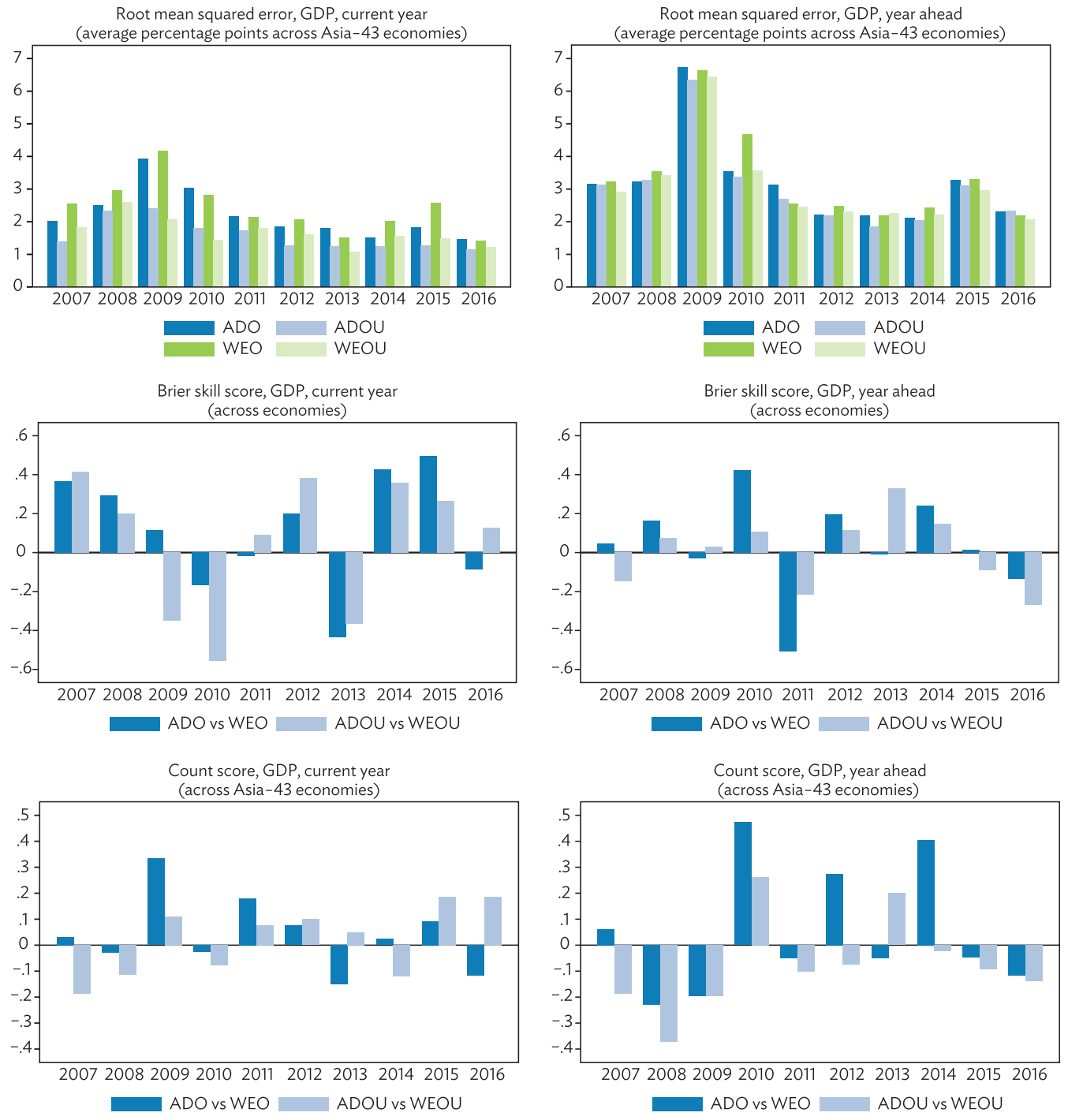

$\mathrm{ADO}=$ Asian Development Outlook, $\mathrm{ADOU}=$ Asian Development Outlook Update, GDP = gross domestic product, $\mathrm{vs}=$ versus, $\mathrm{WEO}=$ World Economic Outlook, WEOU $=$ World Economic Outlook Update.

Source: Author's calculations. 
Figure A5.2: Asia-43 Inflation (Consumer Price Index) Current Year and Year Ahead
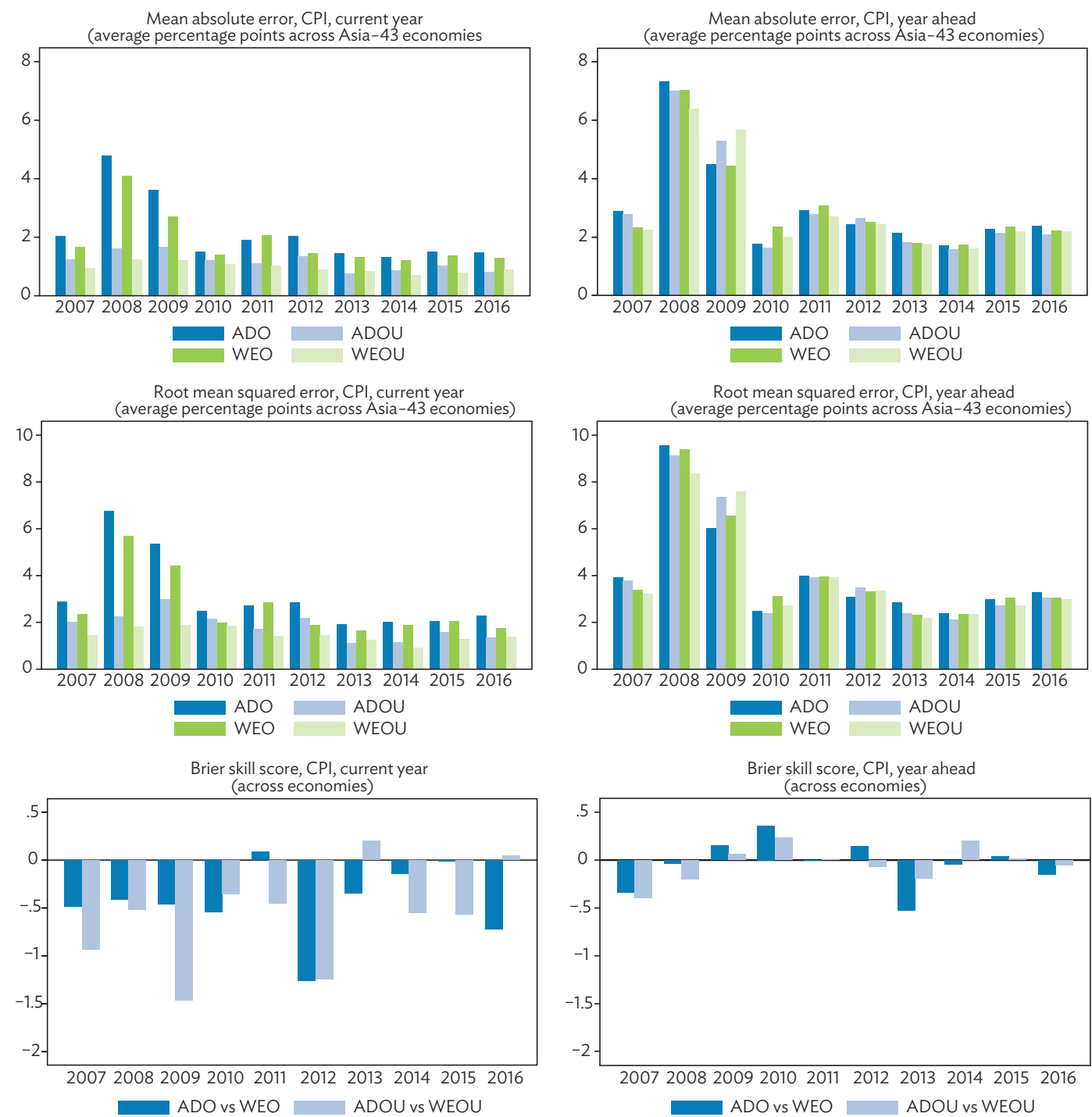

Count score, $\mathrm{CPI}$, current year
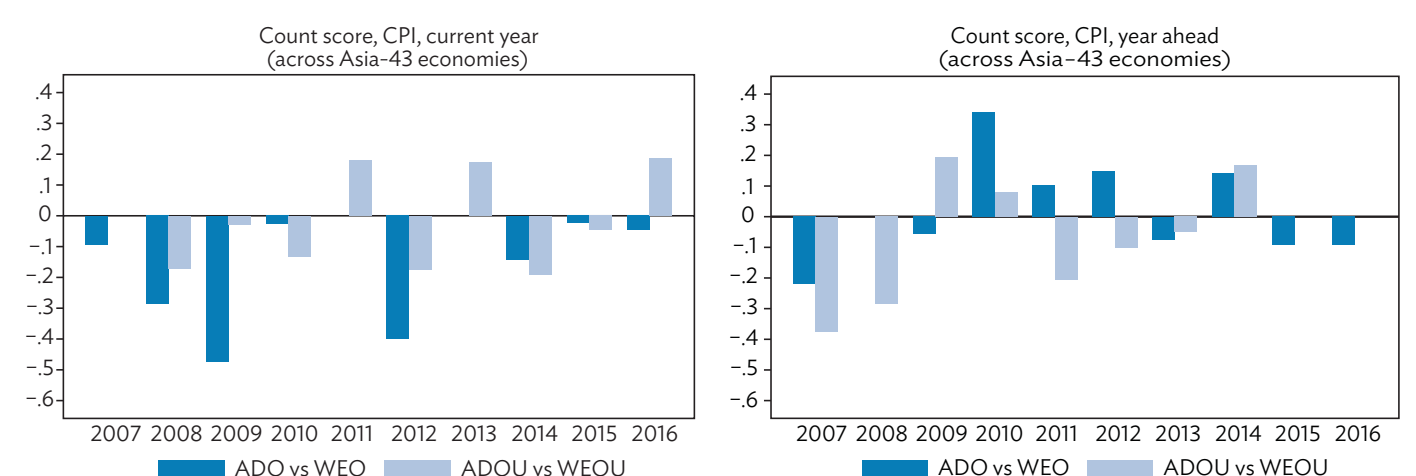

$\mathrm{ADO}=$ Asian Development Outlook, $\mathrm{ADOU}=$ Asian Development Outlook Update, $\mathrm{CPI}=$ Consumer Price Index, $\mathrm{vs}=$ versus, $\mathrm{WEO}=$ World Economic Outlook, WEOU $=$ World Economic Outlook Update.

Source: Author's calculations. 


\section{Appendix 6: Asia-43 Forecast Errors and Brier Scores by Economies}

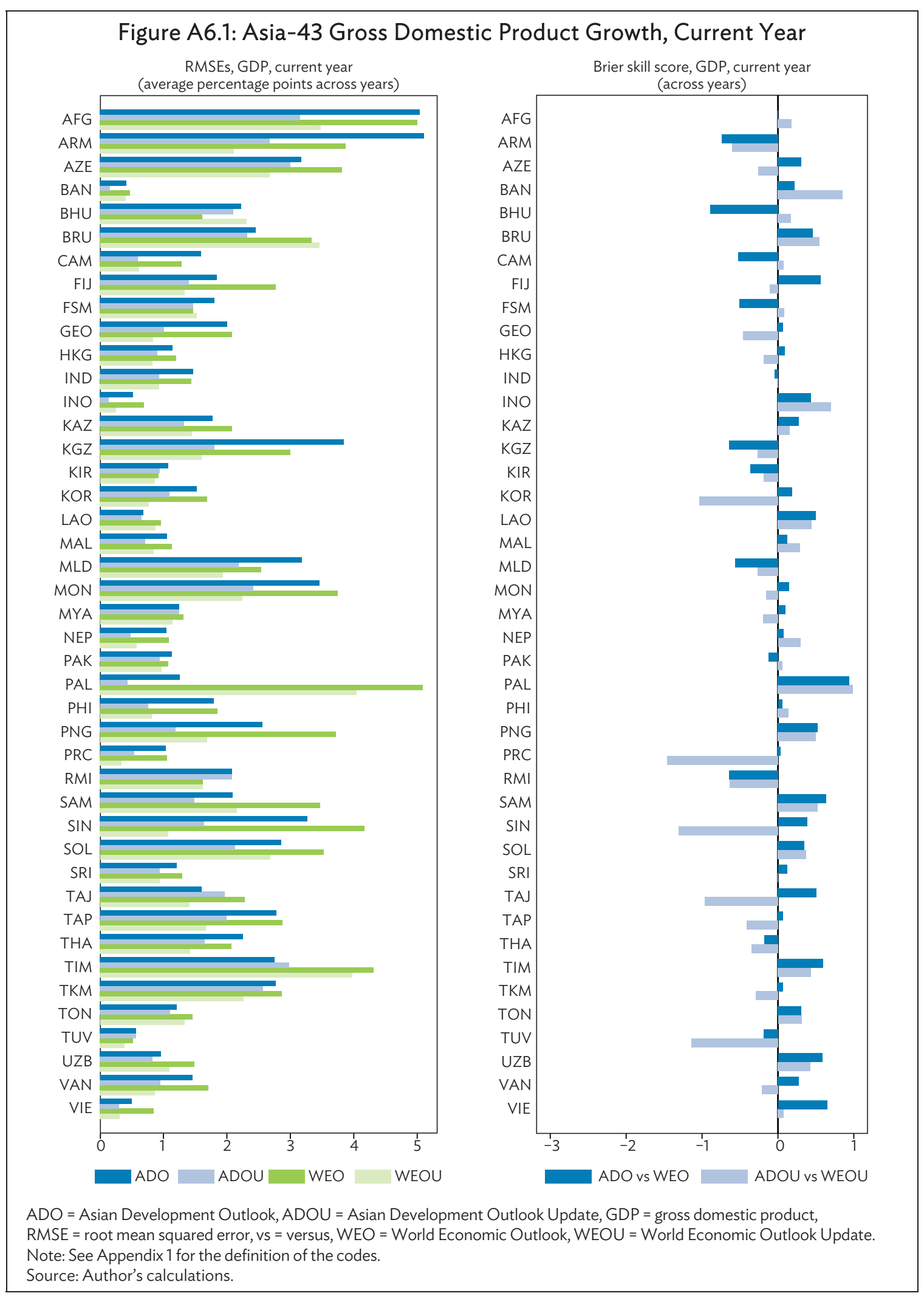




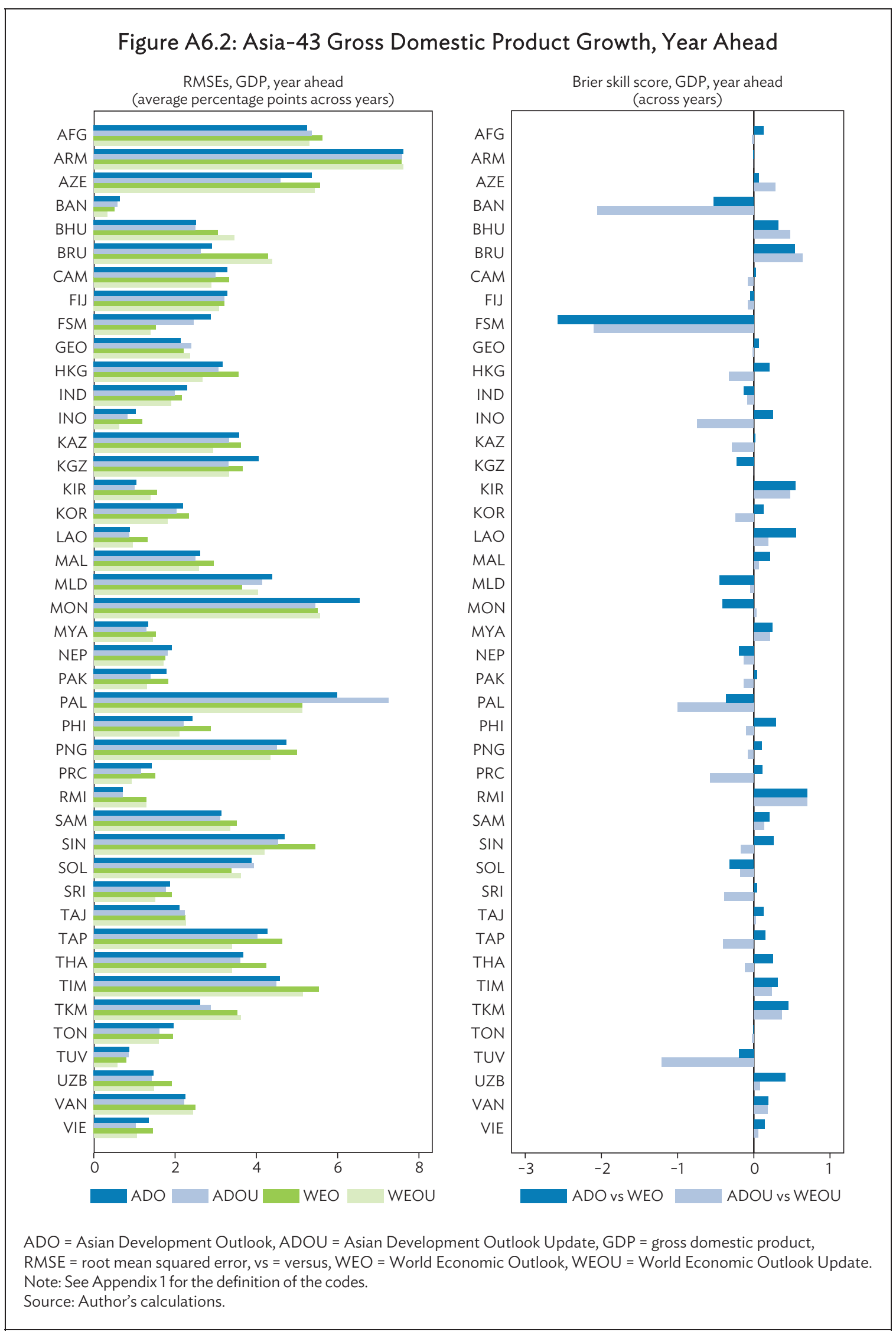




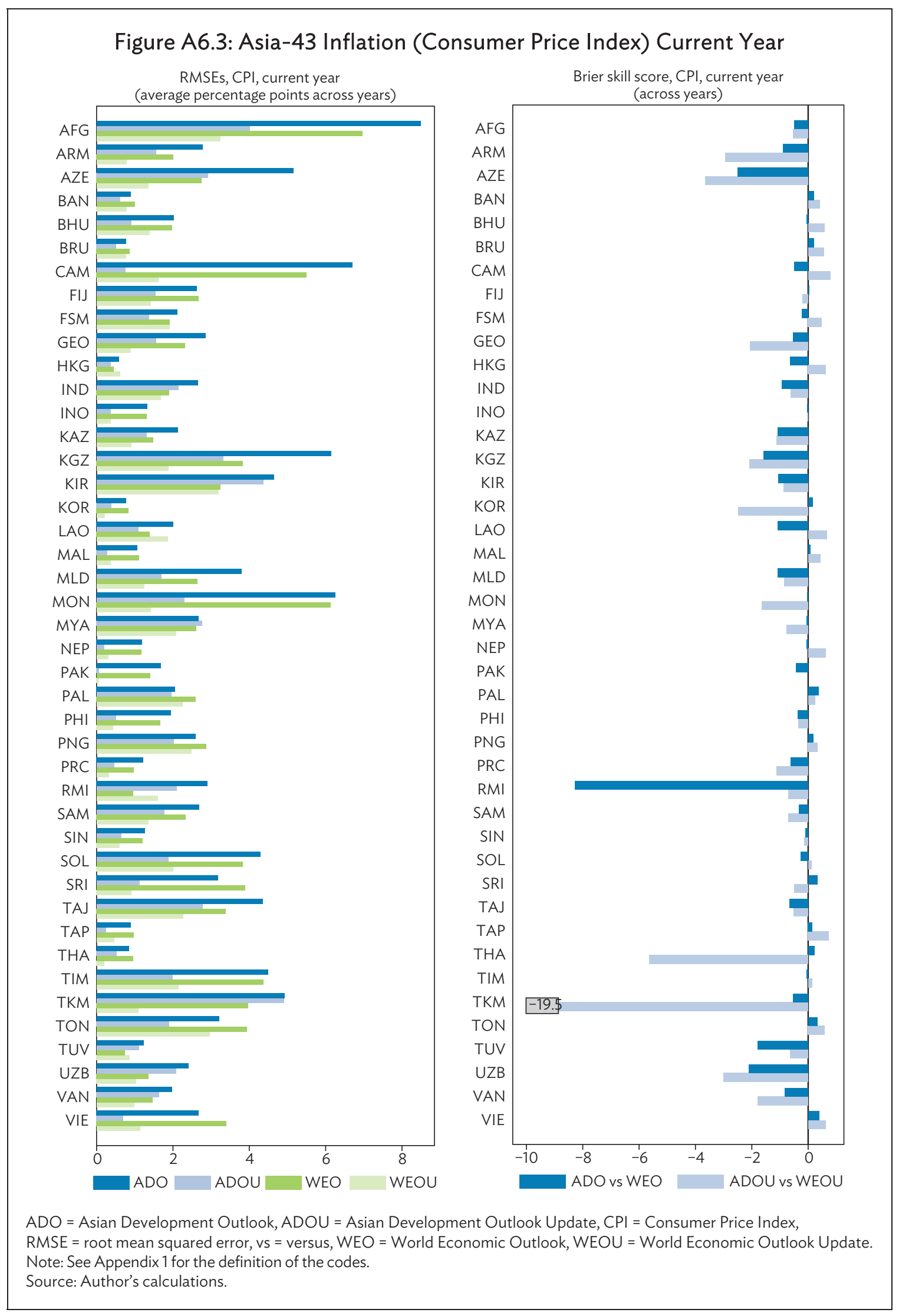




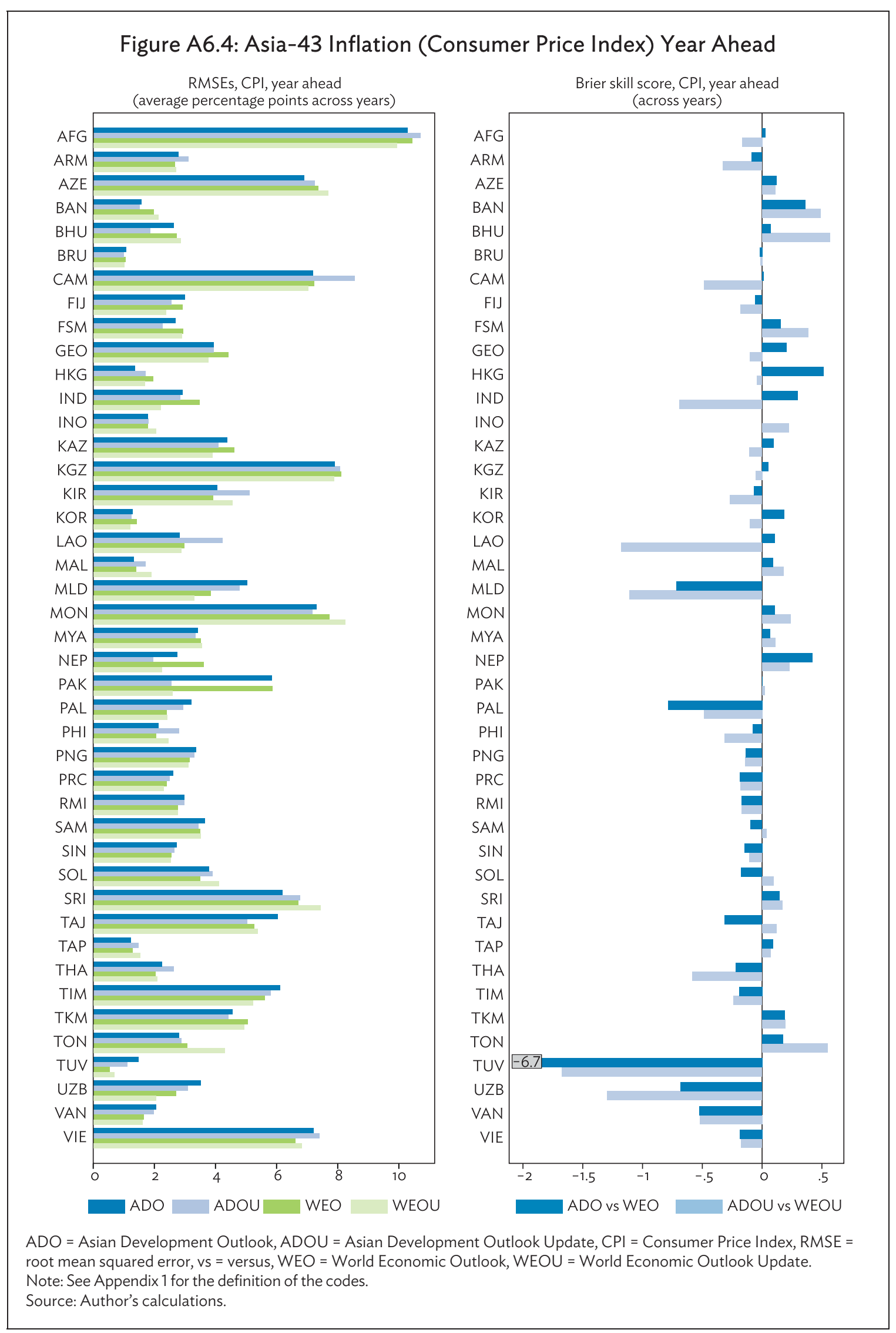


Appendix 7: Asia-11 Growth and Inflation Forecast Errors by Economies, Reports, and Years

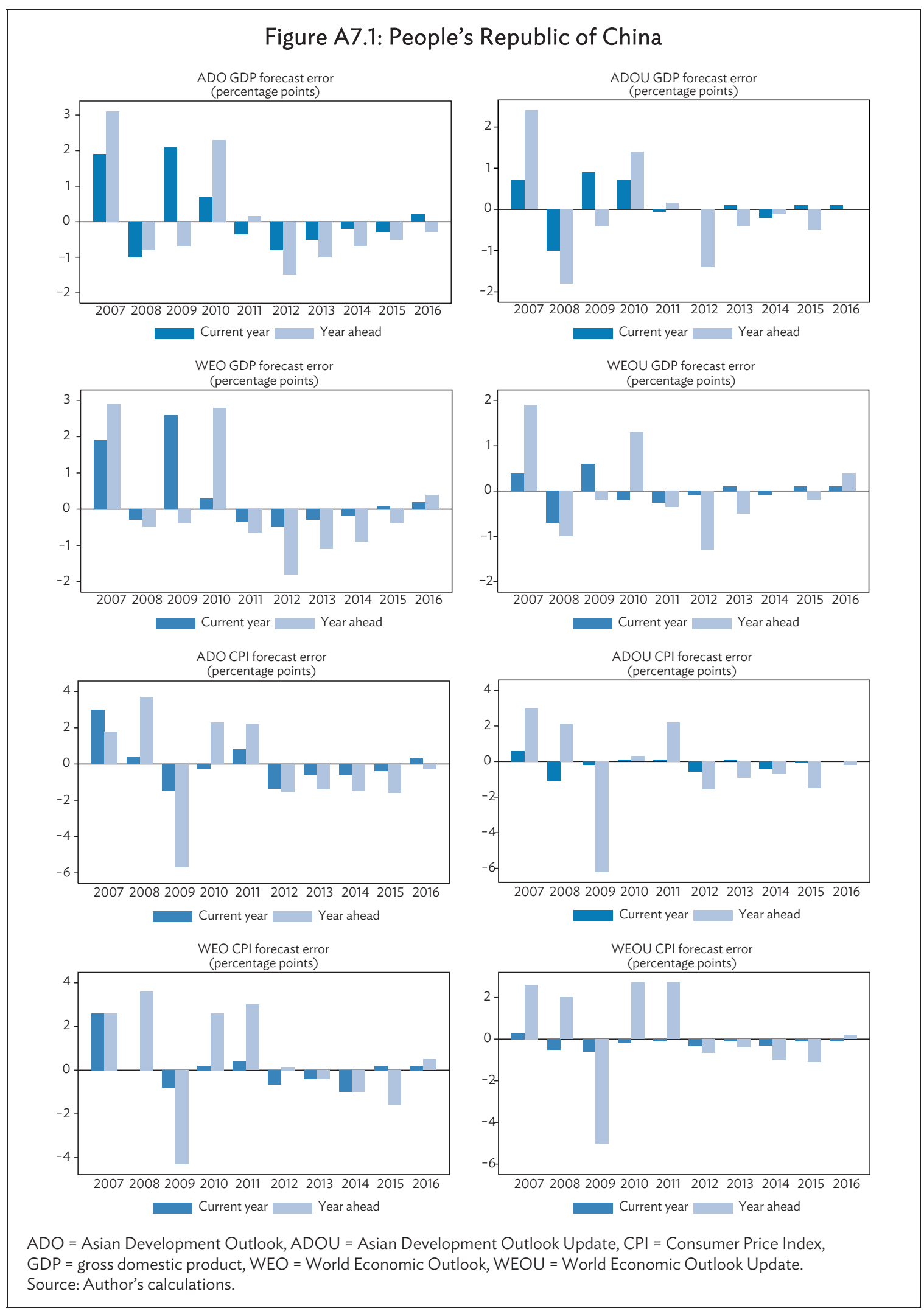




\section{Figure A7.2: Hong Kong, China}
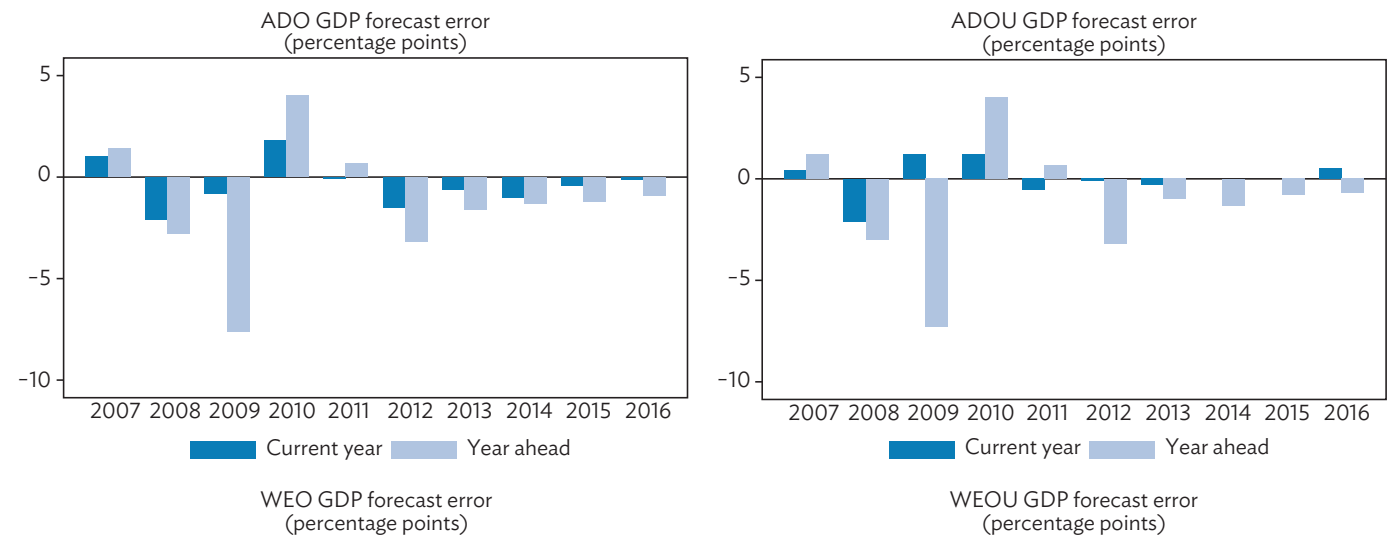

2007200820092010201120122013201420152016

Current year Year ahead (percentage points)
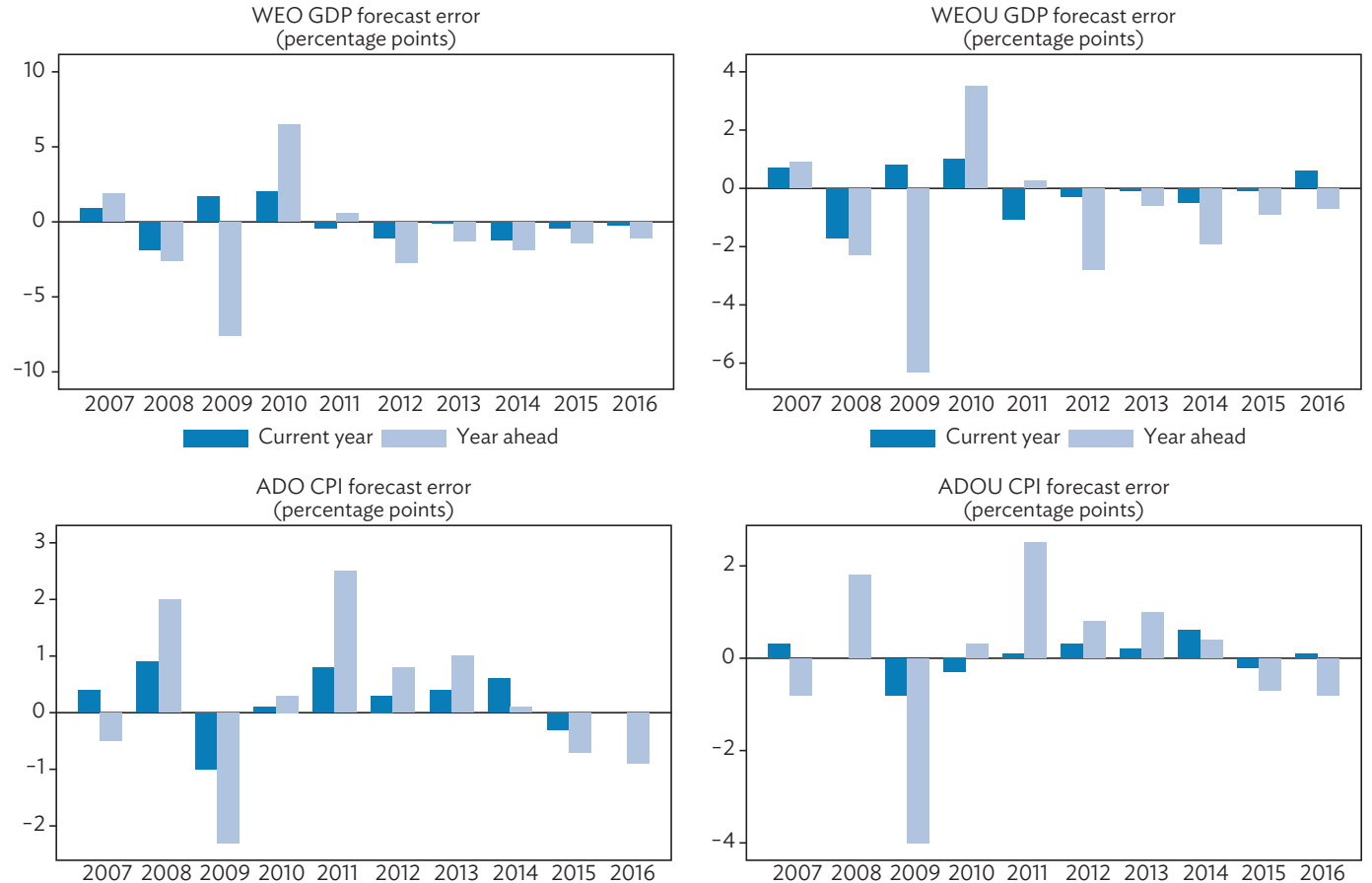
(percentage points)

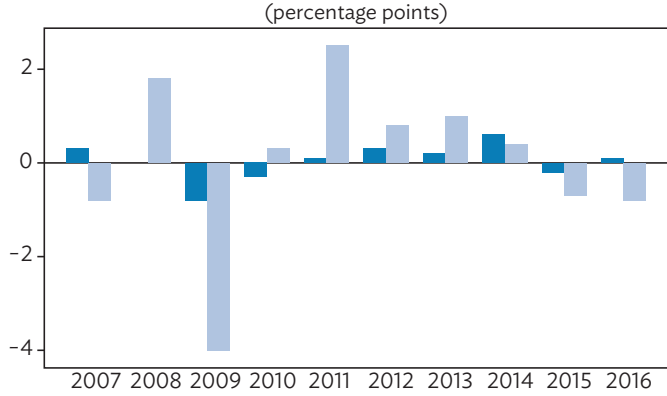

Current year Year ahead

Current year Year ahead WEO CPI forecast error

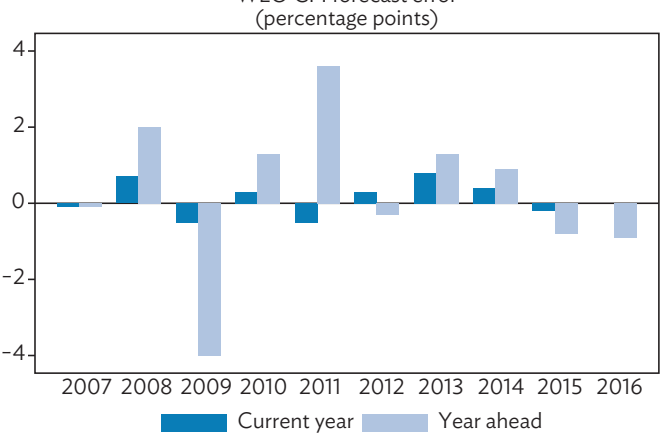
WEOU CPI forecast error (percentage points)

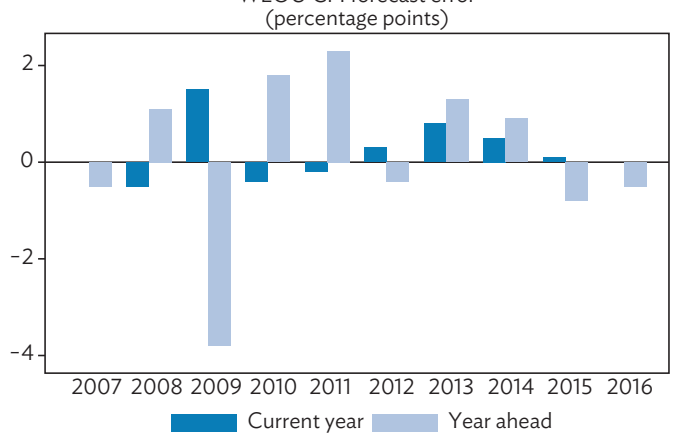

$\mathrm{ADO}=$ Asian Development Outlook, $\mathrm{ADOU}=$ Asian Development Outlook Update, $\mathrm{CPI}=$ Consumer Price Index $\mathrm{GDP}=$ gross domestic product, $\mathrm{WEO}=$ World Economic Outlook, $\mathrm{WEOU}=$ World Economic Outlook Update. Source: Author's calculations. 
Figure A7.3: Indonesia
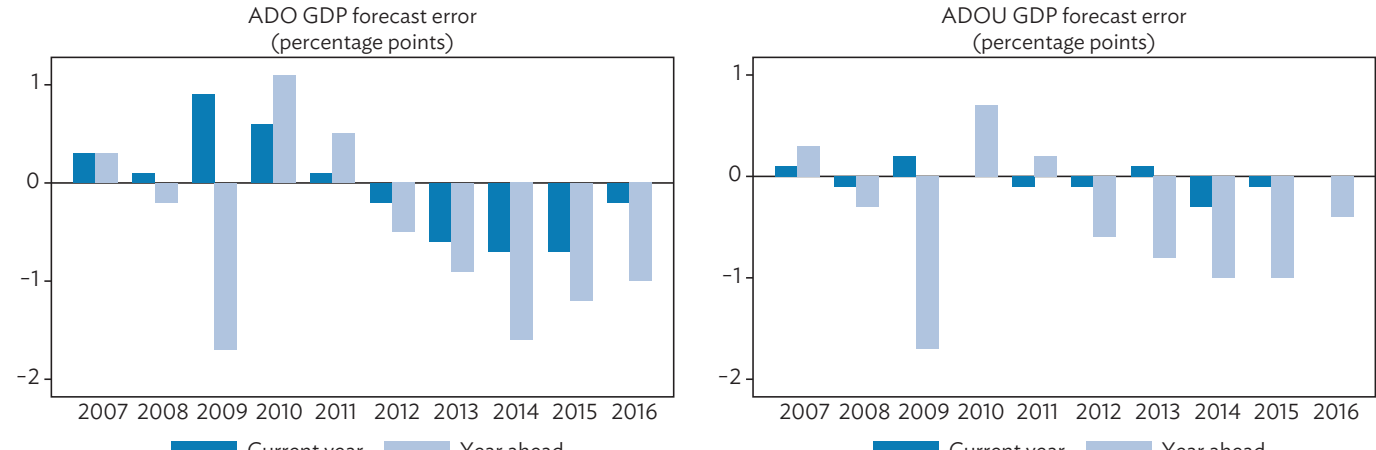

Current year Year ahead

Current year Year ahead

WEO GDP forecast error

(percentage points)
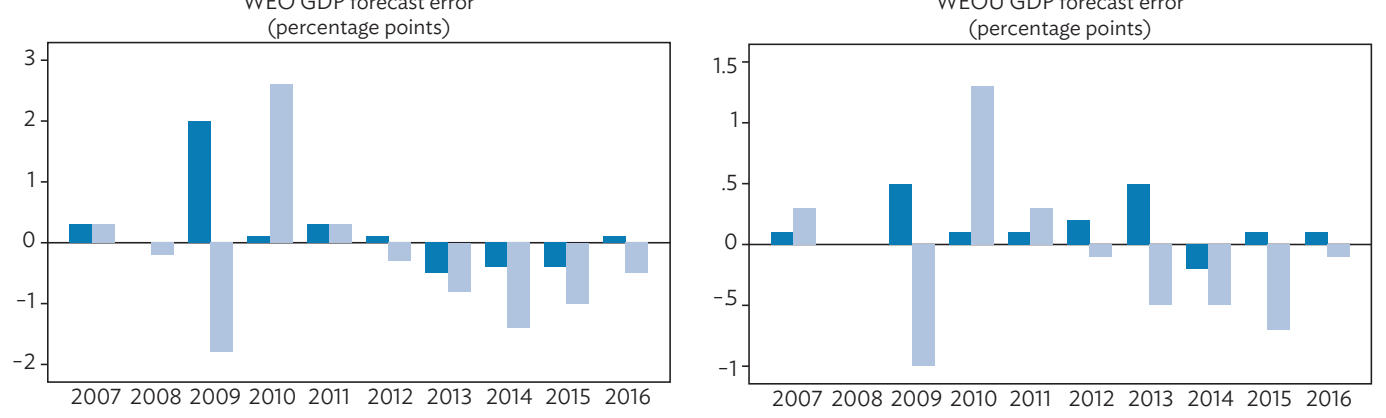

Current year Year ahead

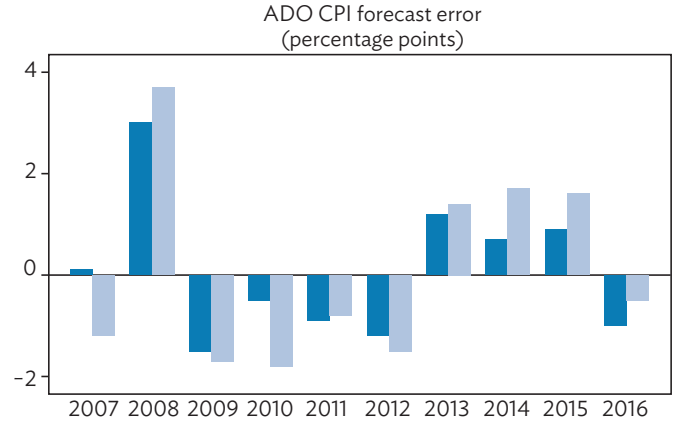

Current year $\quad$ Year ahead
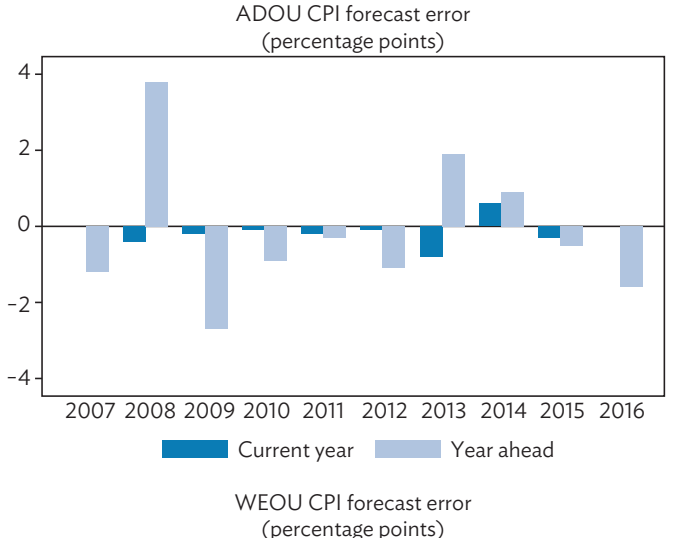

WEO CPI forecast error (percentage points)
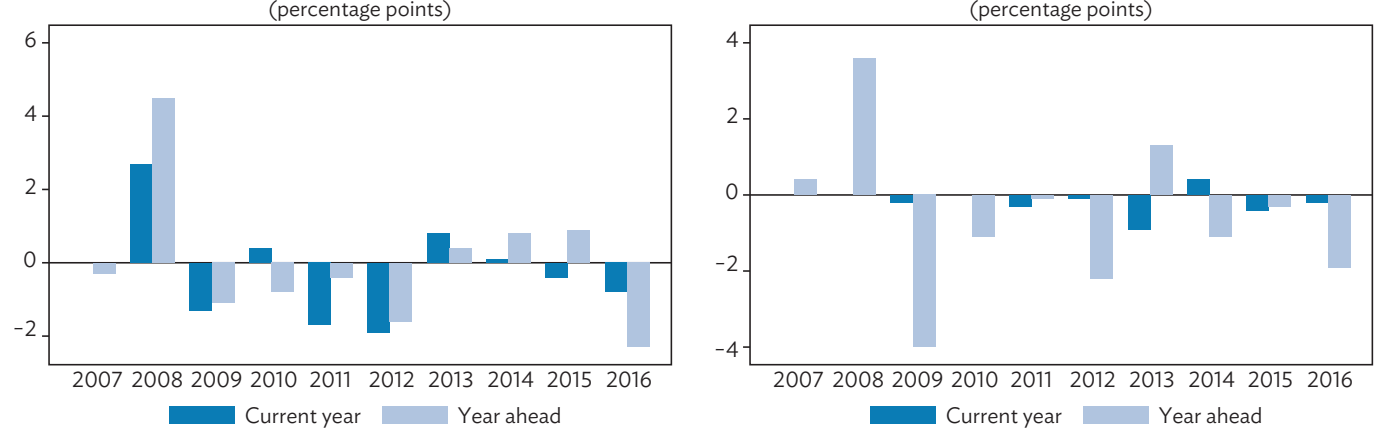

$\mathrm{ADO}=$ Asian Development Outlook, $\mathrm{ADOU}=$ Asian Development Outlook Update, $\mathrm{CPI}=$ Consumer Price Index, GDP = gross domestic product, $\mathrm{WEO}=$ World Economic Outlook, $\mathrm{WEOU}=$ World Economic Outlook Update.

Source: Author's calculations. 
Figure A7.4: India
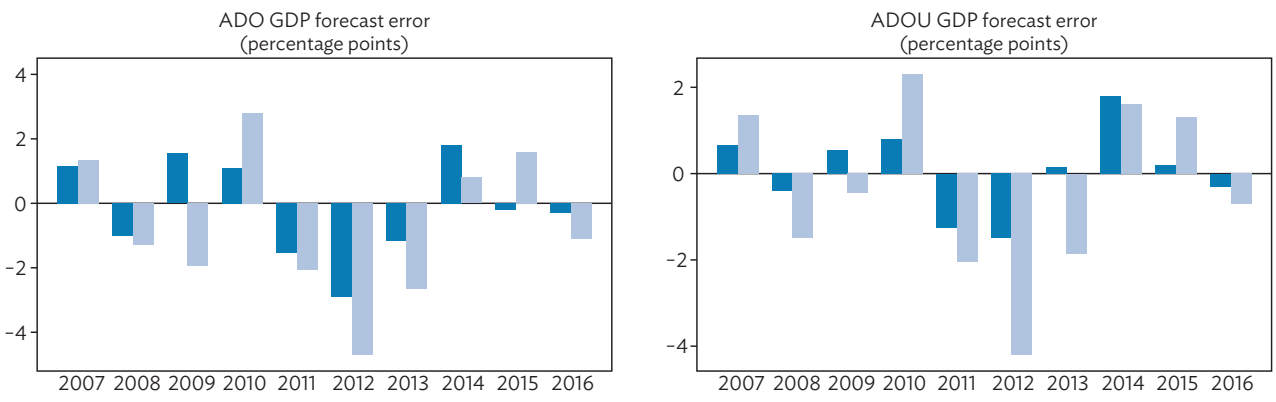

Current year Year ahead

Current year Year ahead

WEO GDP forecast erro

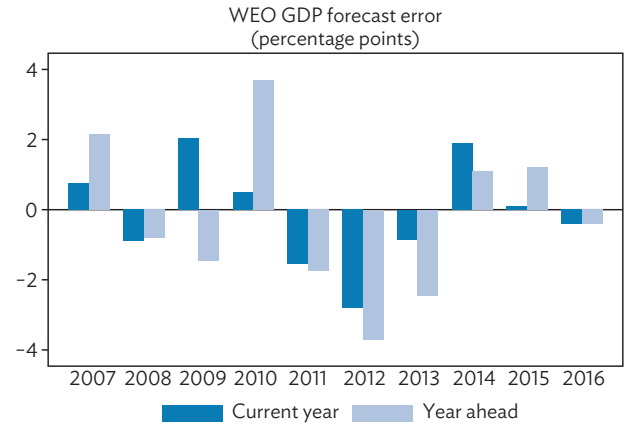

WEOU GDP forecast erro

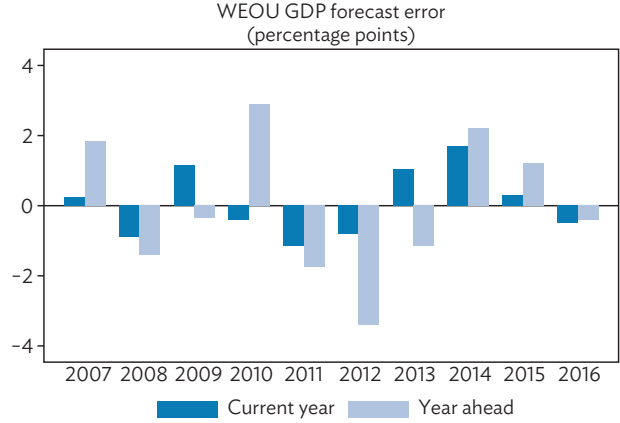

ADO CPI forecast error

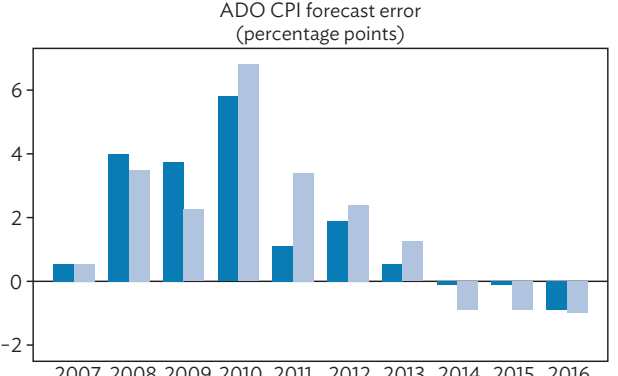

ADOU CPI forecast erro

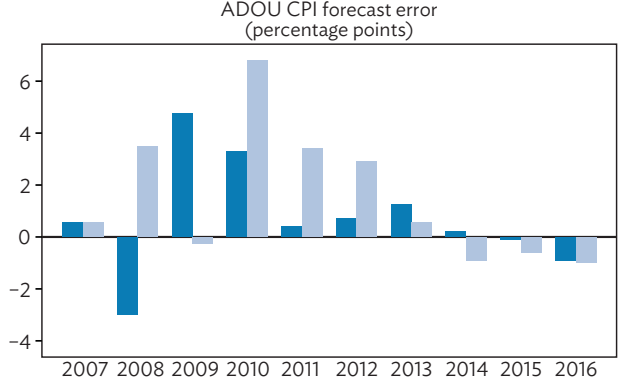

Current year Year ahead

Current year Year ahead

WEO CPI forecast error

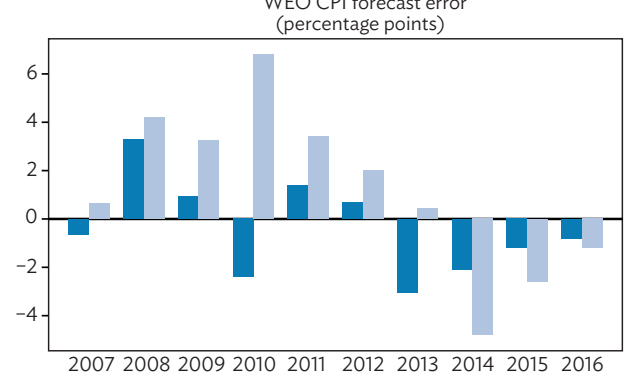

WEOU CPI forecast error

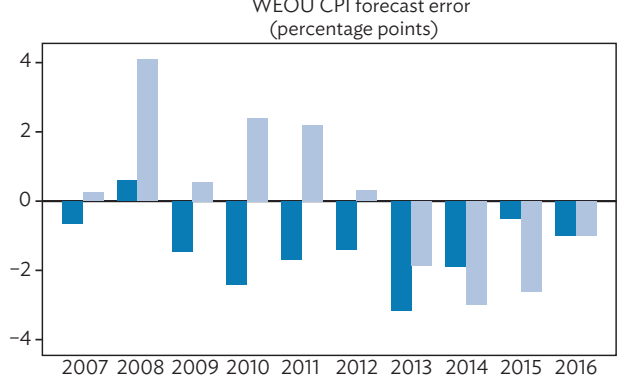

Current year Year ahead

Current year Year ahead

$\mathrm{ADO}=$ Asian Development Outlook, $\mathrm{ADOU}=$ Asian Development Outlook Update, $\mathrm{CPI}=$ Consumer Price Index GDP = gross domestic product, $\mathrm{WEO}=$ World Economic Outlook, WEOU = World Economic Outlook Update . Source: Author's calculations. 


\section{Figure A7.5: Republic of Korea}
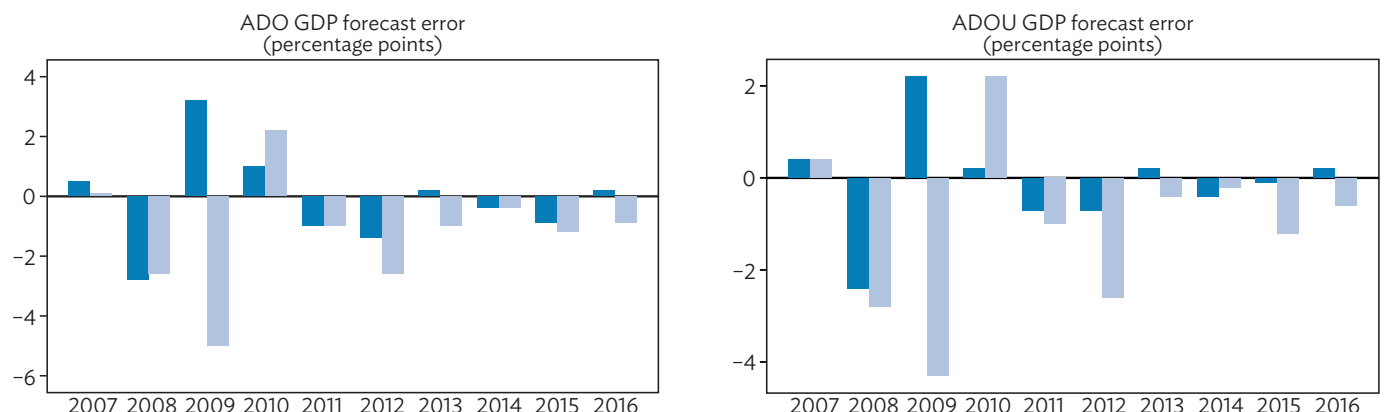

Current year Year ahead

— Current year Year ahead

WEO GDP forecast error

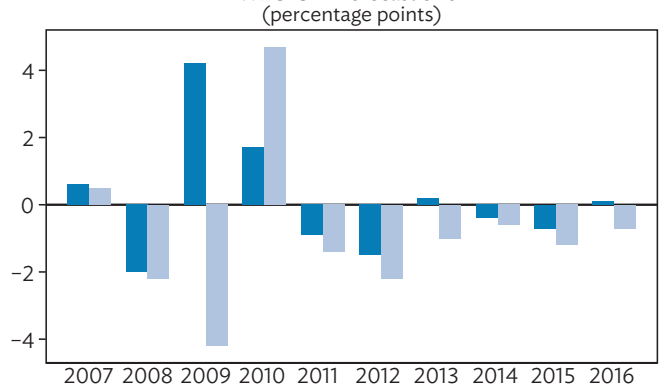

Current year Year ahead

ADO CPI forecast erro
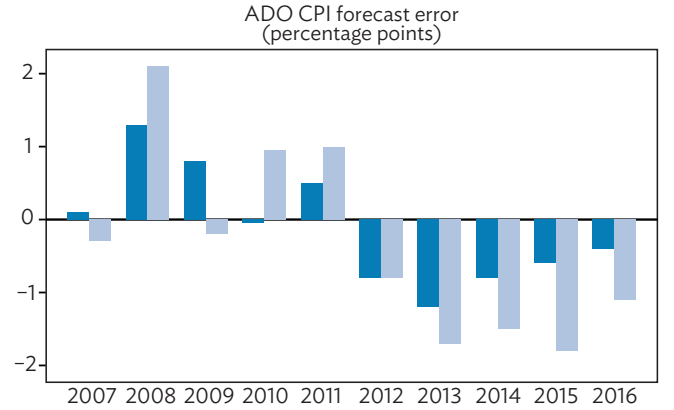

Current year Year ahead

WEO CPI forecast error

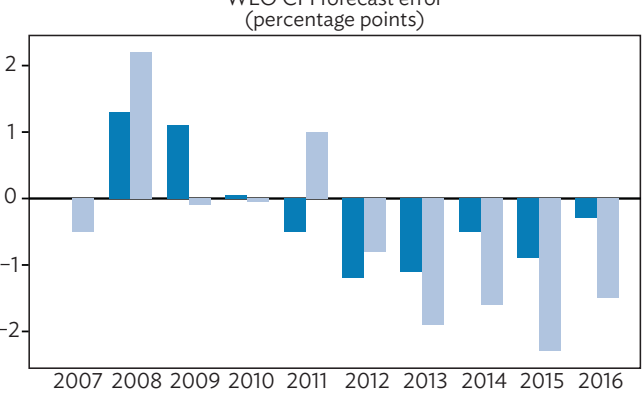

Current year Year ahead

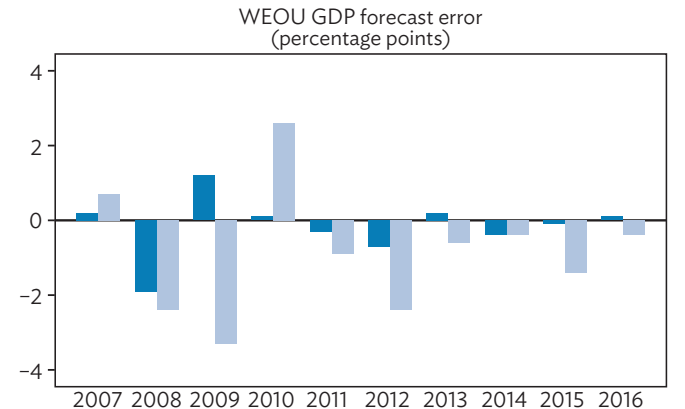

2007200820092010201120122013201420152016

Current year Year ahead ADOU CPI forecast error

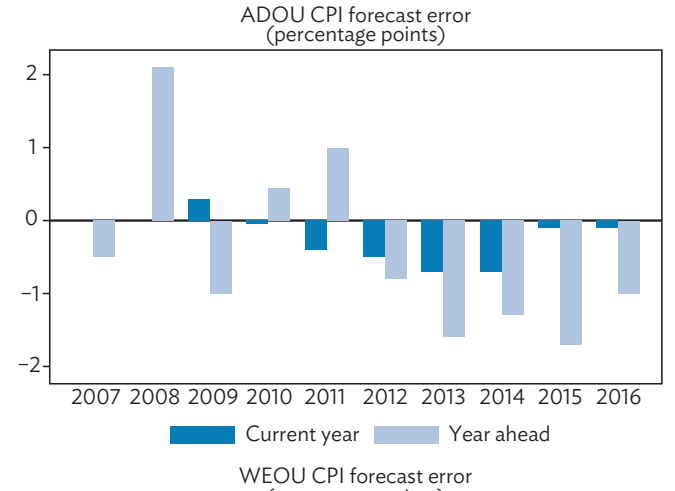
(percentage points)

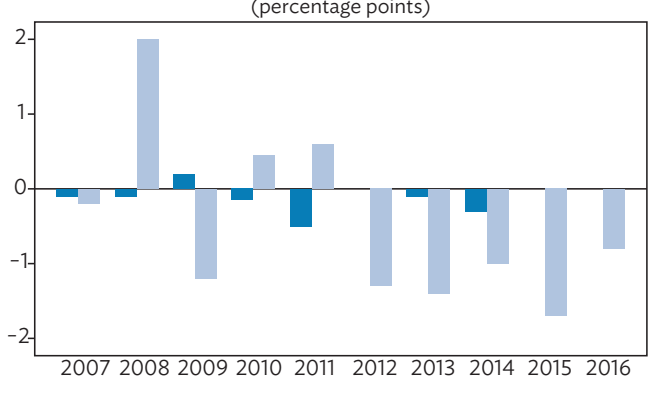

Current year Year ahead

$\mathrm{ADO}=$ Asian Development Outlook, $\mathrm{ADOU}=$ Asian Development Outlook Update, $\mathrm{CPI}=$ Consumer Price Index, GDP $=$ gross domestic product, $\mathrm{WEO}=$ World Economic Outlook, WEOU $=$ World Economic Outlook Update. Source: Author's calculations. 
Figure A7.6: Malaysia
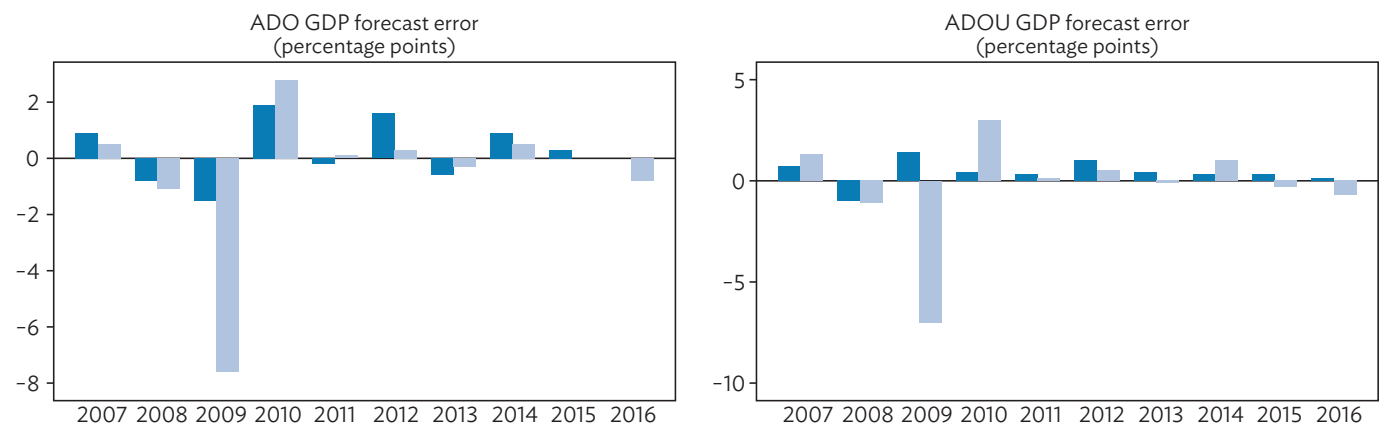

Current year Year ahead

Current year Year ahead

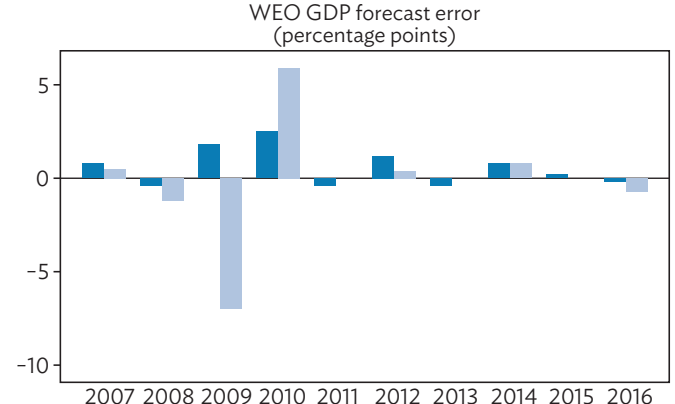

GDP forecast error

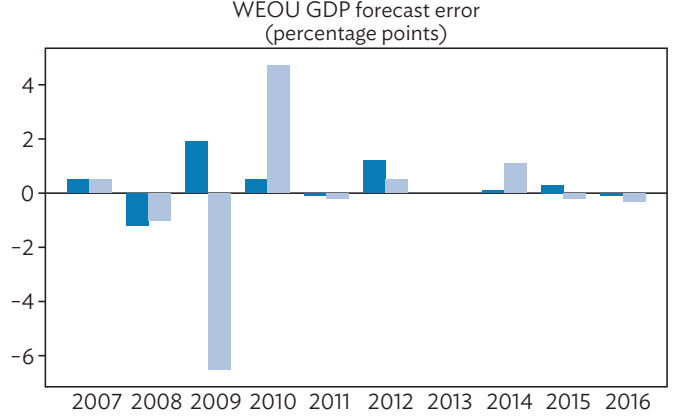

Current year Year ahead

ADO CPI forecast error

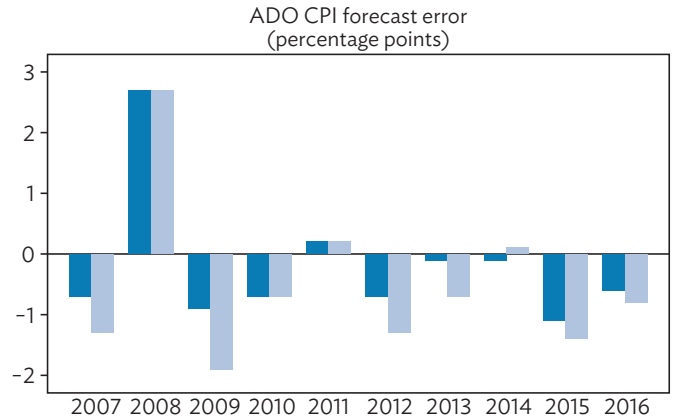

Current year Year ahead

ADOU CPI forecast error

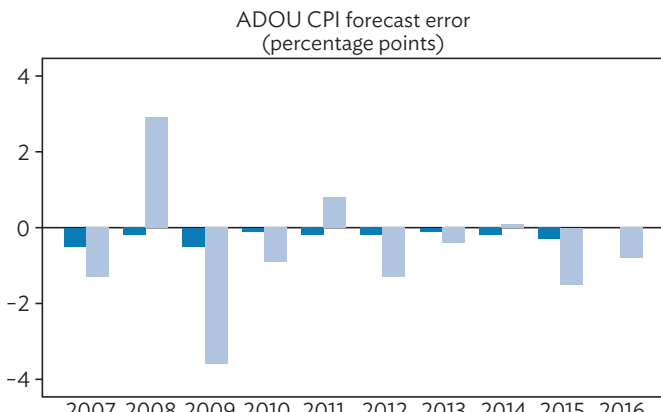

Current year Year ahead

WEO CPI forecast error

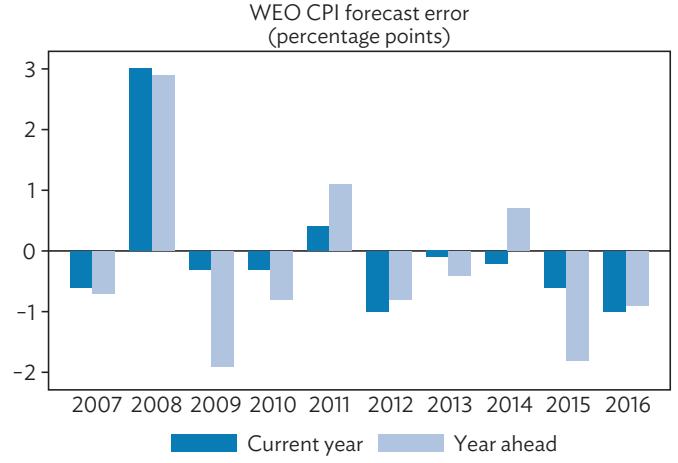

2007200820092010201120122013201420152016

Current year Year ahead

WEOU CPI forecast error (percentage points)

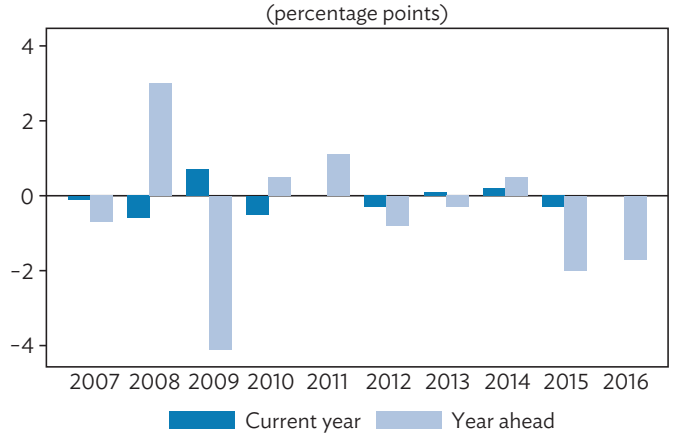

$\mathrm{ADO}=$ Asian Development Outlook, $\mathrm{ADOU}=$ Asian Development Outlook Update, $\mathrm{CPI}=$ Consumer Price Index, $\mathrm{GDP}=$ gross domestic product, $\mathrm{WEO}=$ World Economic Outlook, WEOU = World Economic Outlook Update. Source: Author's calculations. 
Figure A7.7: Philippines
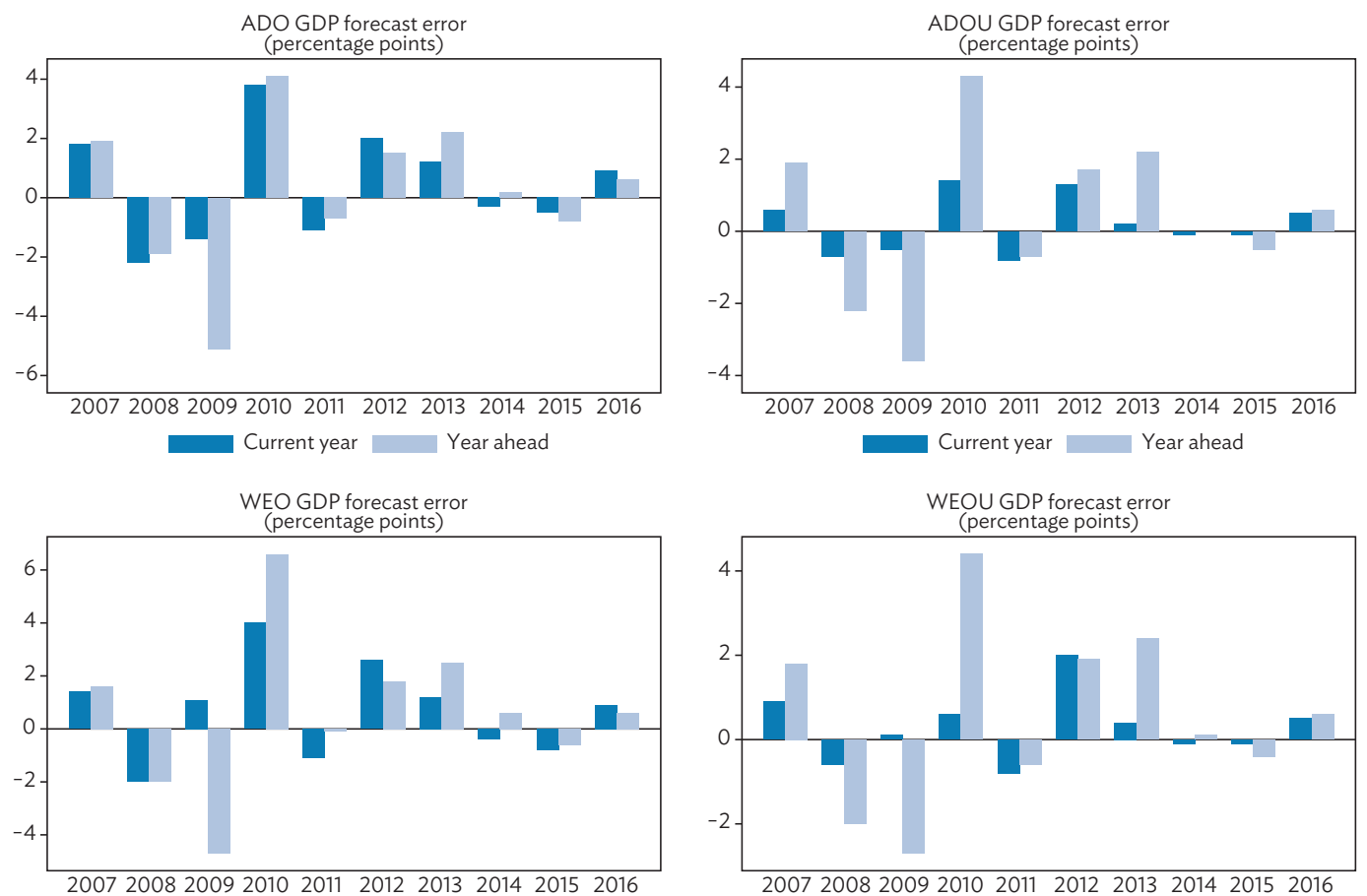

Current year Year ahead

Current year Year ahead
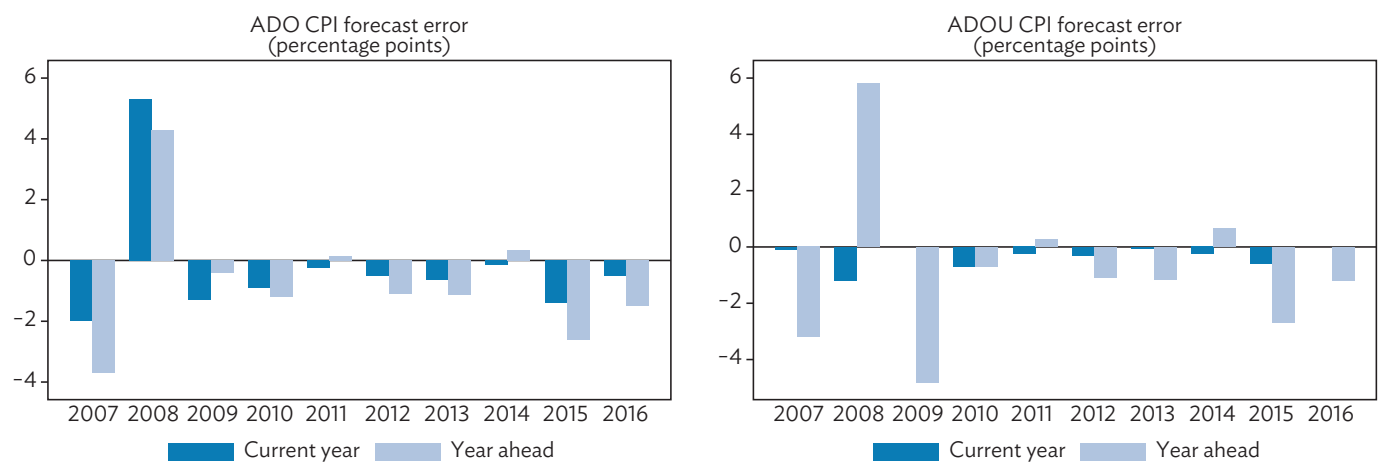

2007200820092010201120122013201420152016

Current year Year ahead
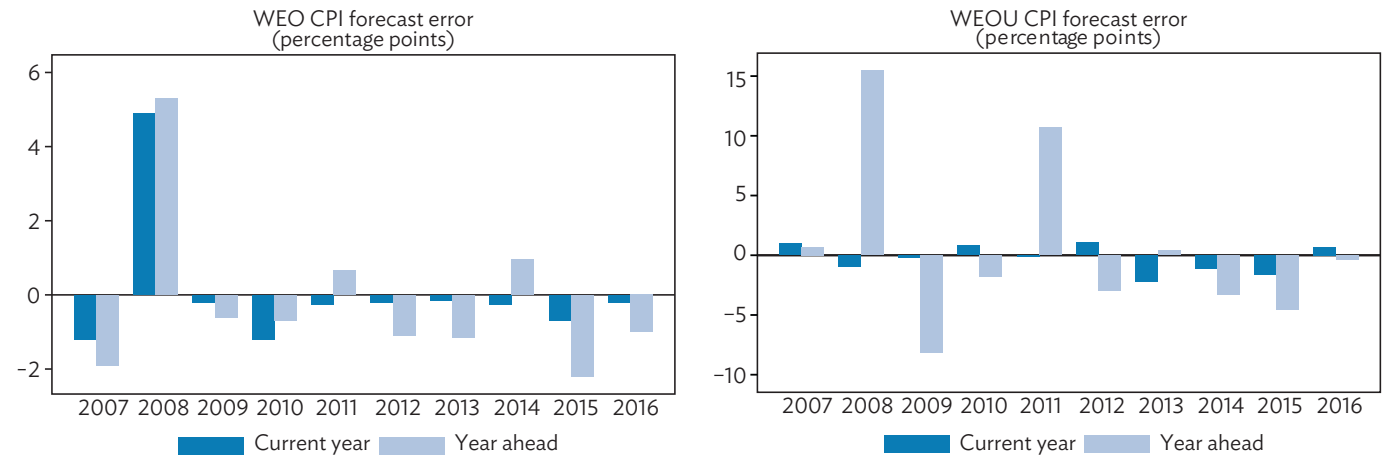

$\mathrm{ADO}=$ Asian Development Outlook, $\mathrm{ADOU}=$ Asian Development Outlook Update, $\mathrm{CPI}=$ Consumer Price Index, GDP $=$ gross domestic product, $\mathrm{WEO}=$ World Economic Outlook, WEOU = World Economic Outlook Update. Source: Author's calculations. 
Figure A7.8: Singapore
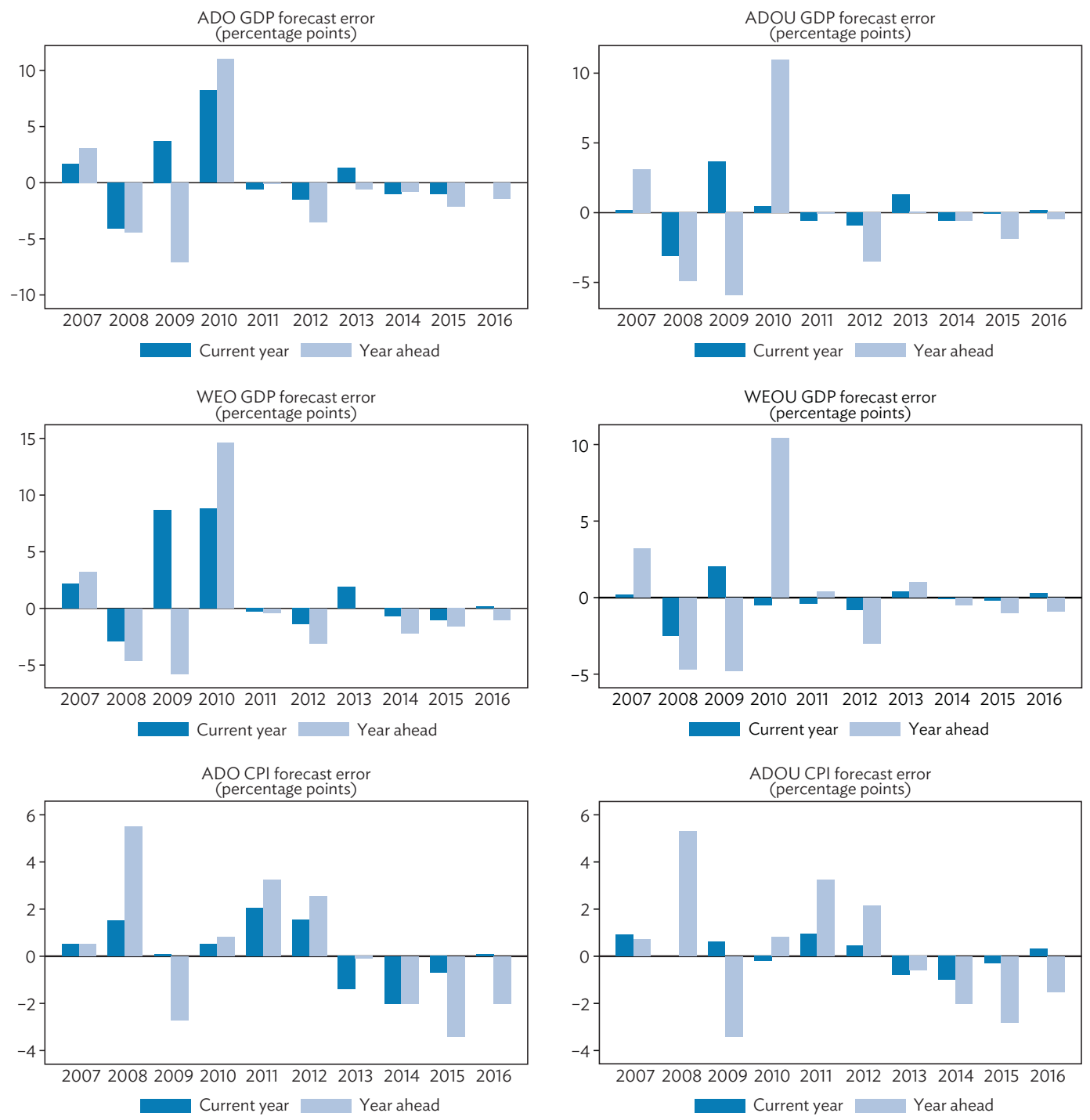

WEO CPI forecast error
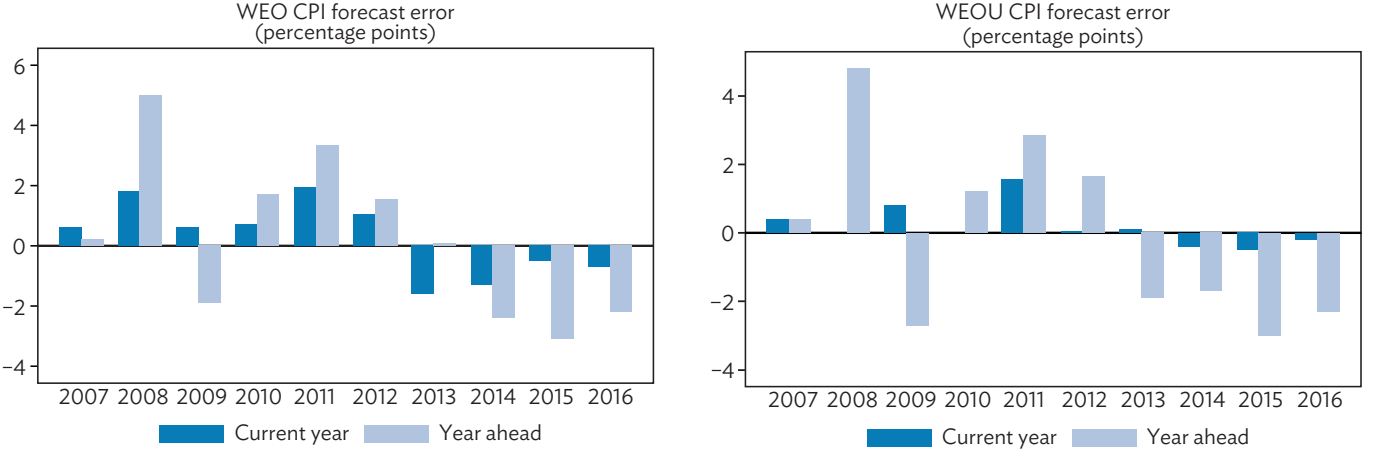

$\mathrm{ADO}=$ Asian Development Outlook, $\mathrm{ADOU}=$ Asian Development Outlook Update, $\mathrm{CPI}=$ Consumer Price Index $\mathrm{GDP}=$ gross domestic product, $\mathrm{WEO}=$ World Economic Outlook, WEOU = World Economic Outlook Update . Source: Author's calculations. 


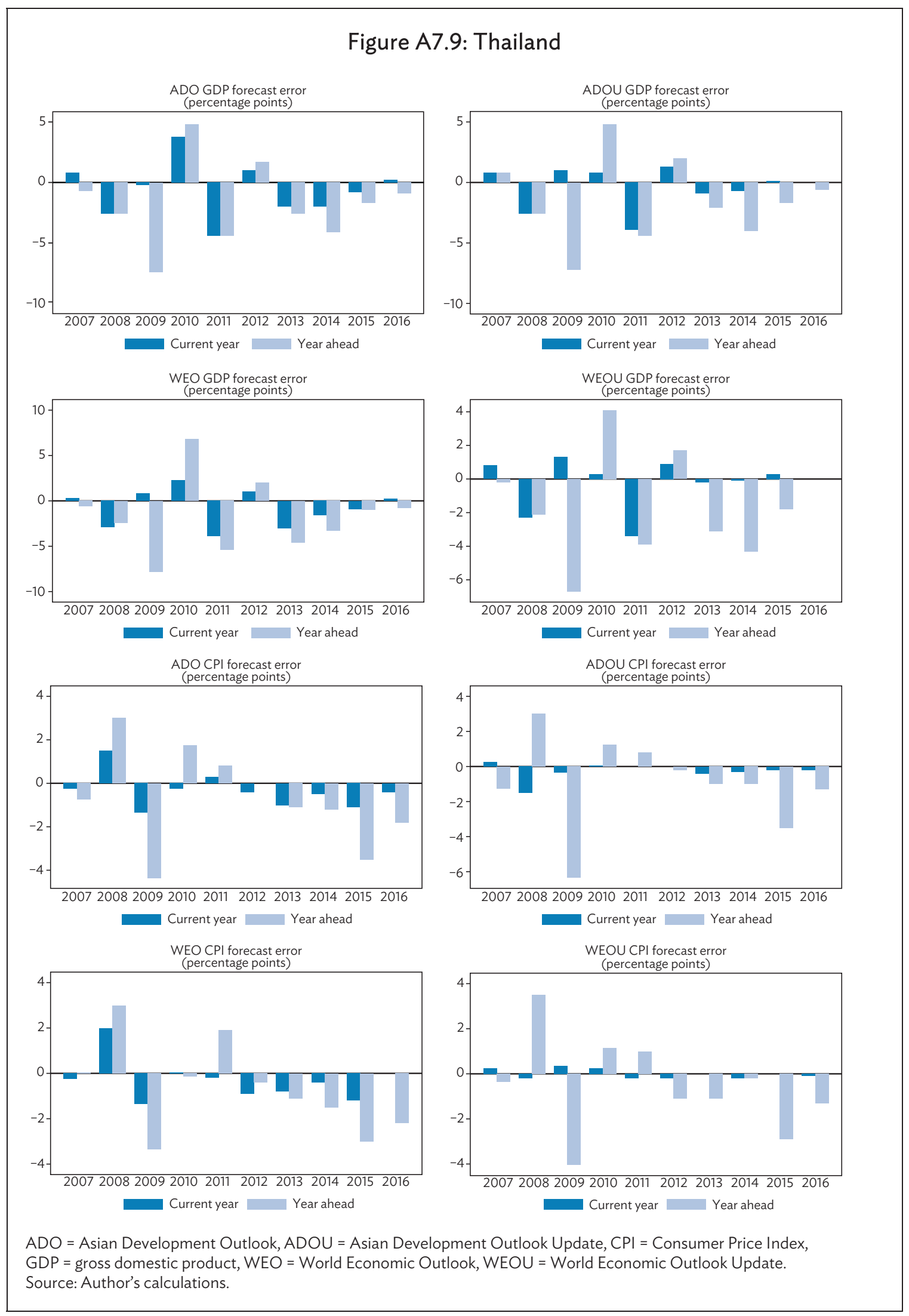


Figure A7.10: Taipei,China
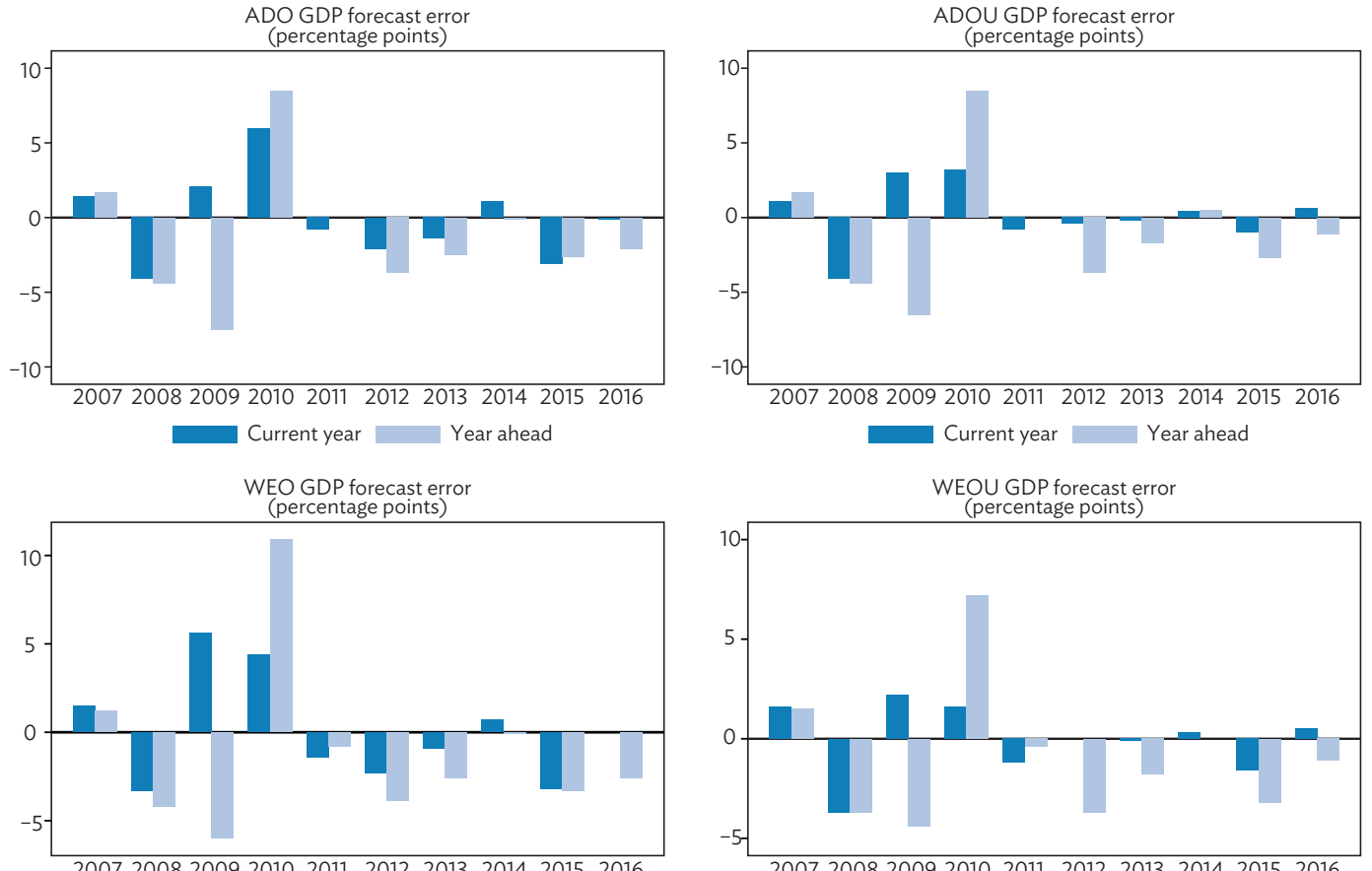

2007200820092010201120122013201420152016

Current year Year ahead

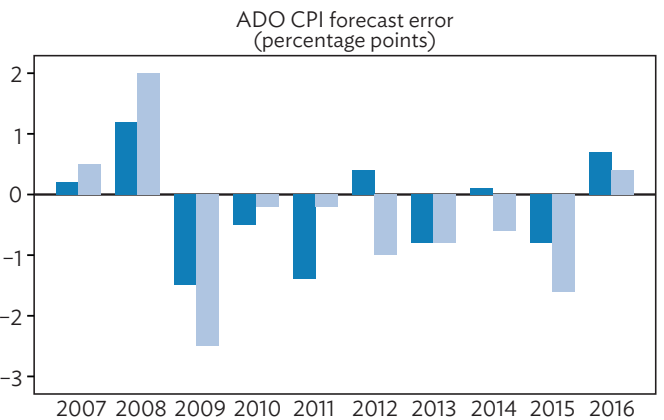

2007200820092010201120122013201420152016

Current year Year ahead

WEO CPI forecast error
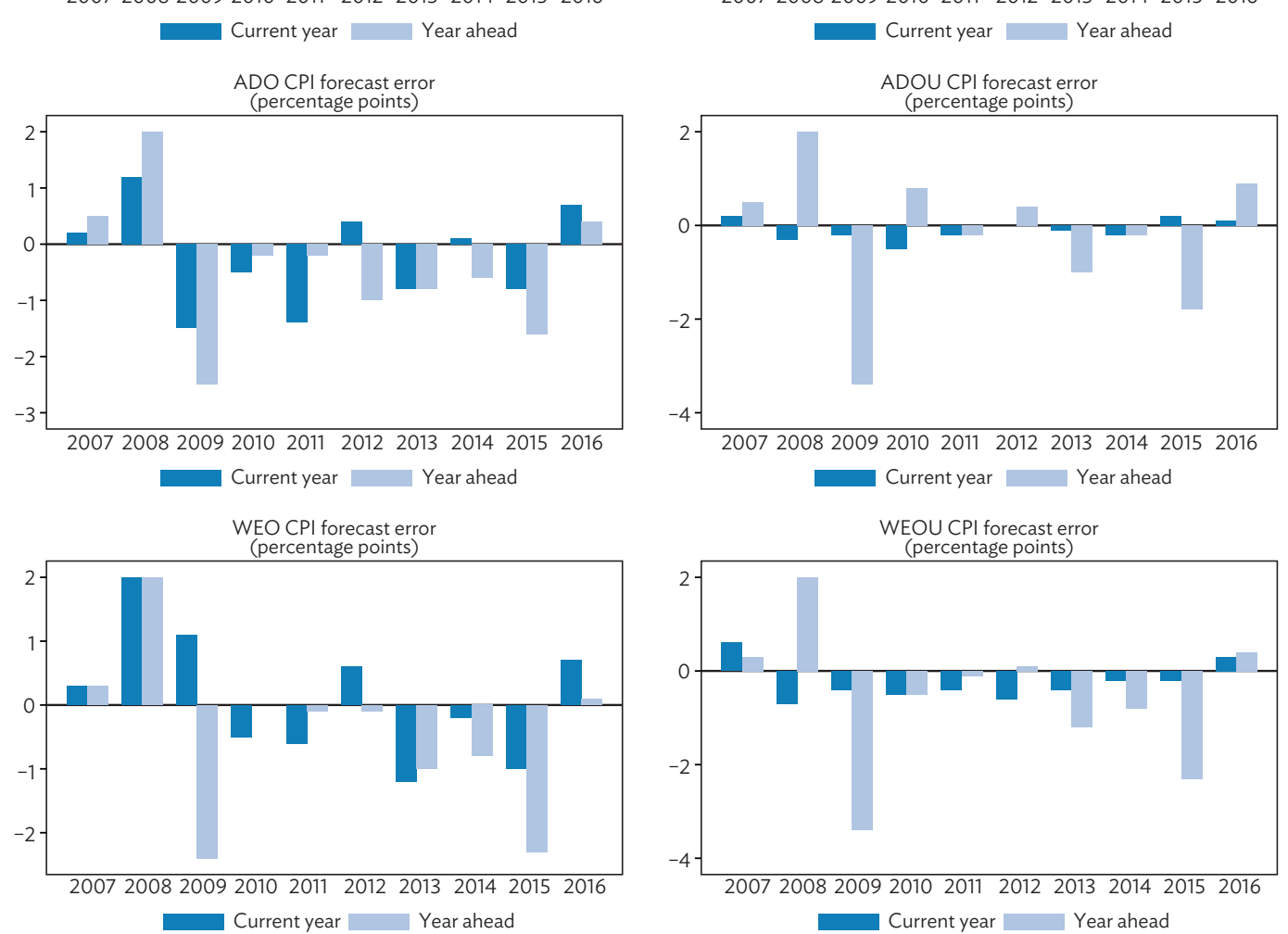

$\mathrm{ADO}=$ Asian Development Outlook, $\mathrm{ADOU}=$ Asian Development Outlook Update, $\mathrm{CPI}=$ Consumer Price Index, $\mathrm{GDP}=$ gross domestic product, WEO = World Economic Outlook, WEOU = World Economic Outlook Update.

Source: Author's calculations. 


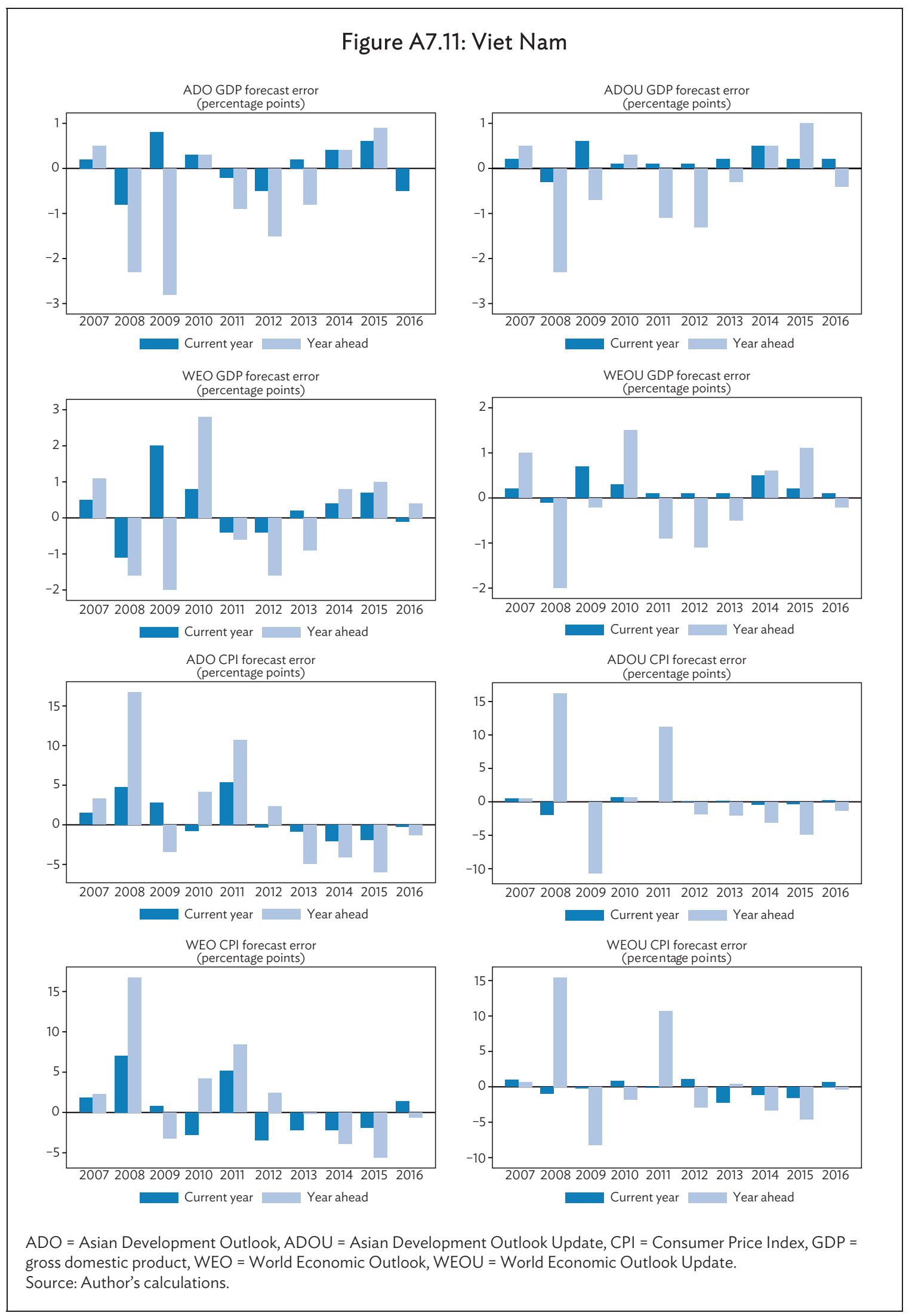




\section{Appendix 8: G3 Growth and Inflation Forecast Errors}

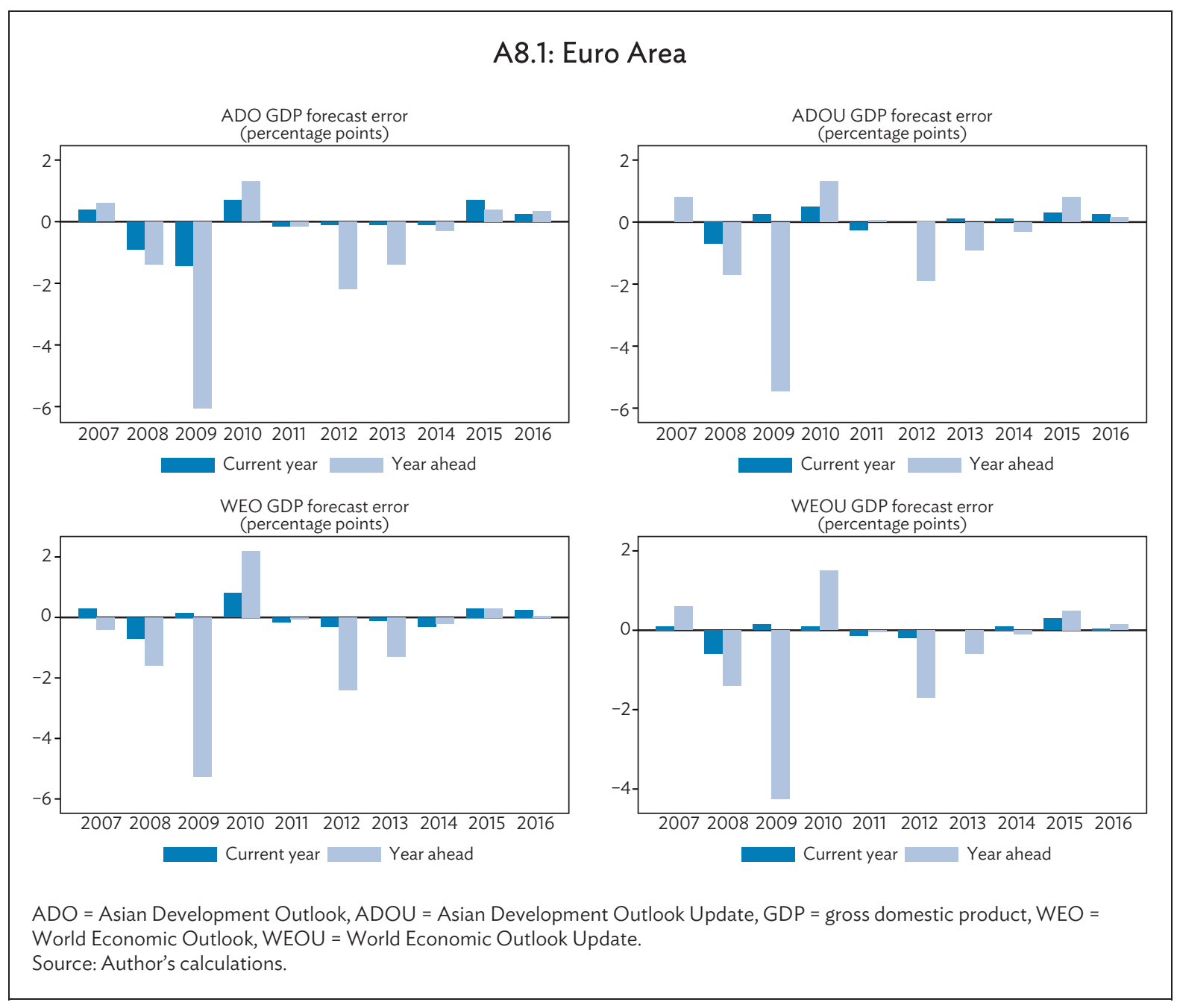




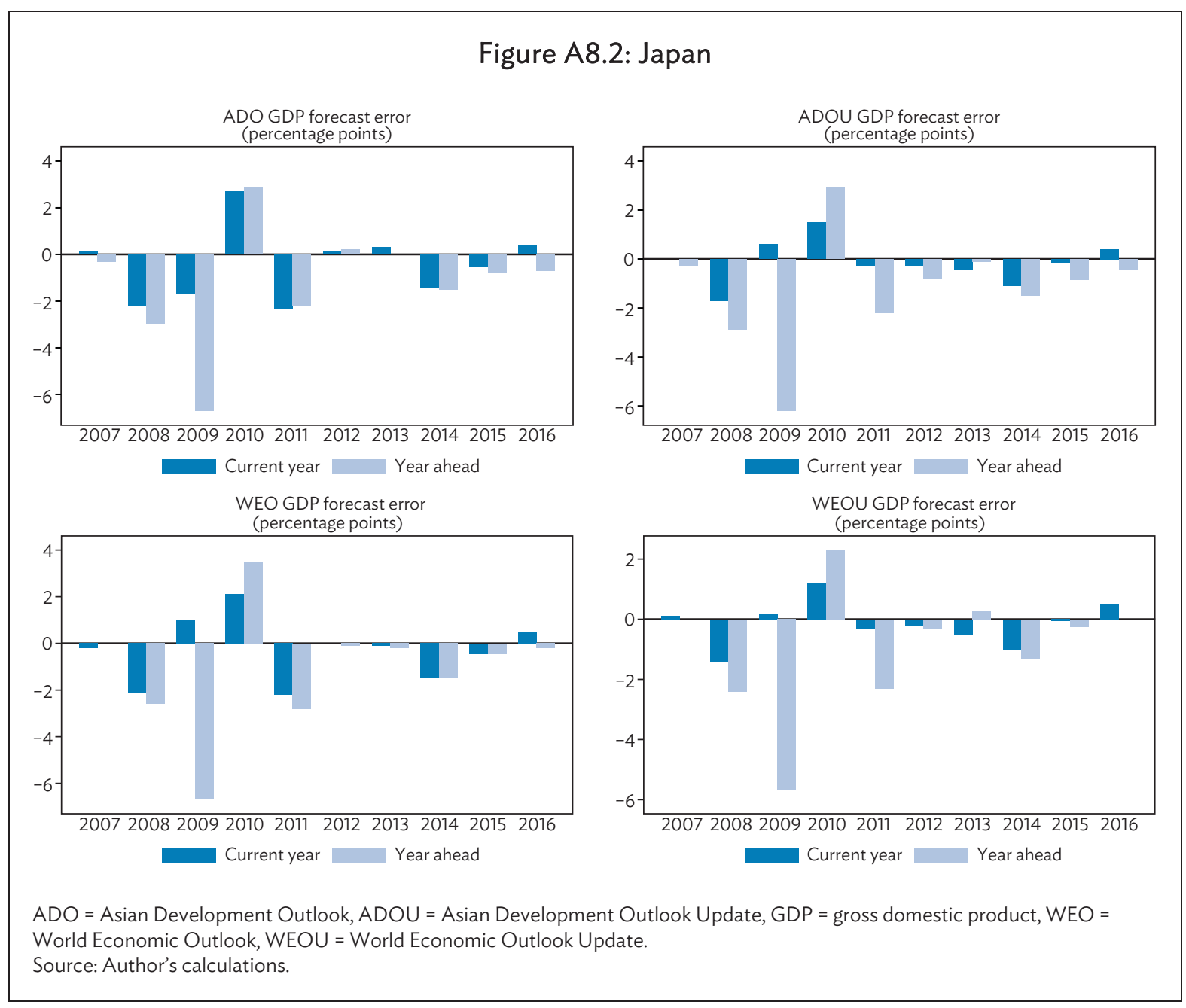


Figure A8.3: United States
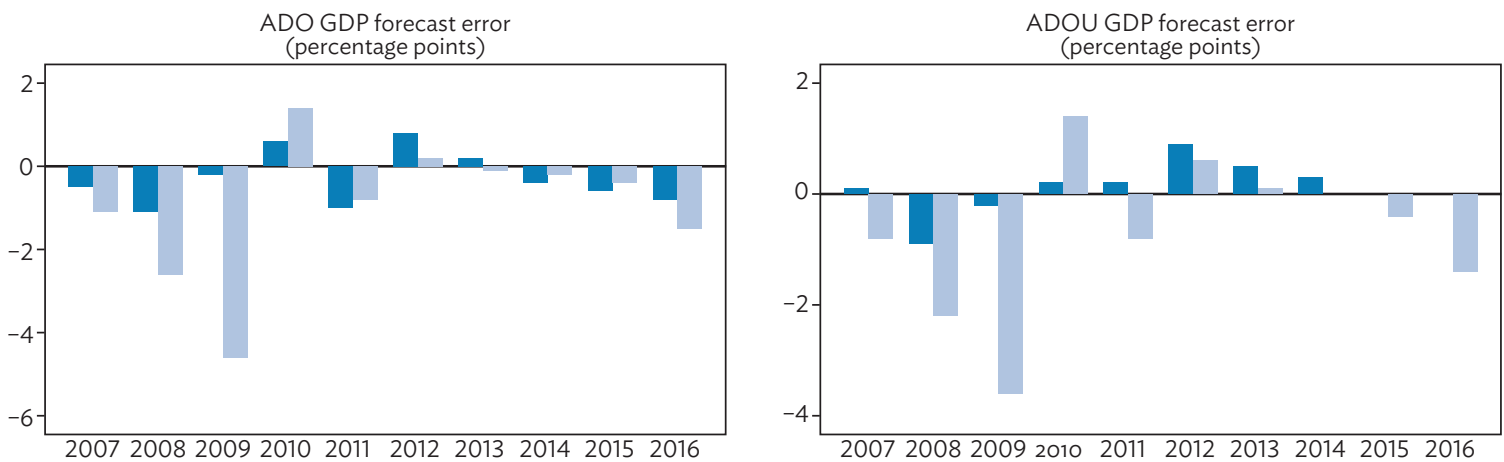

Current year Year ahead 2007200820092010201120122013201420152016
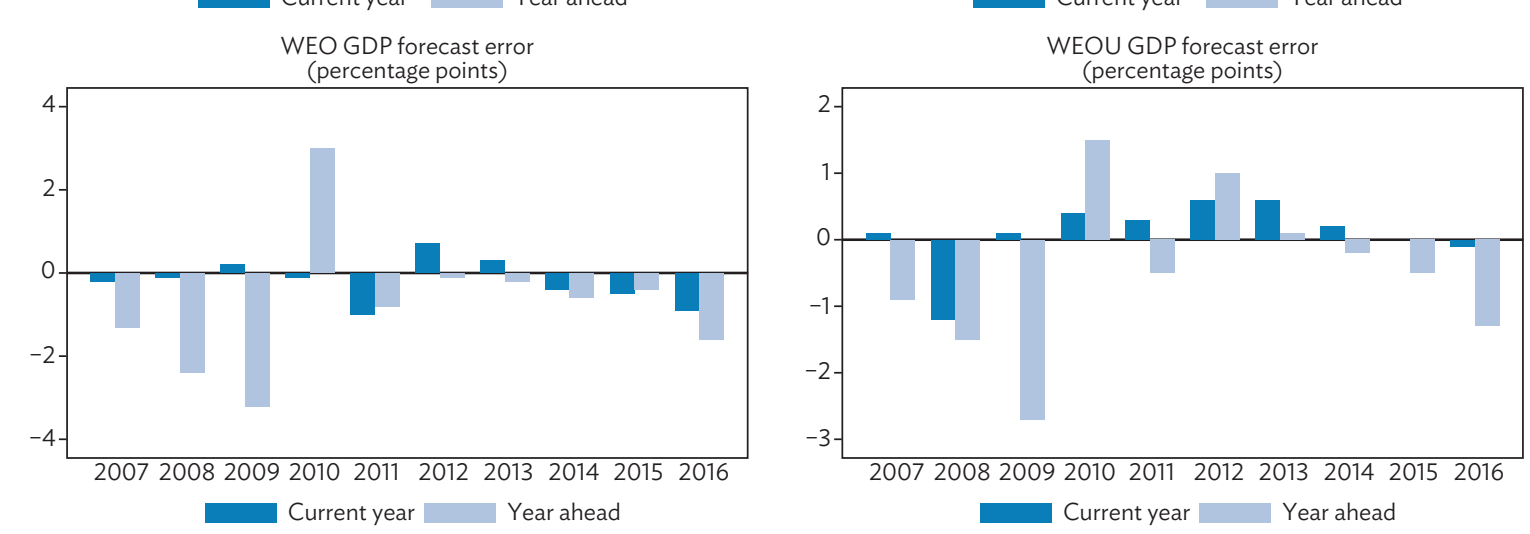

$\mathrm{ADO}=$ Asian Development Outlook, $\mathrm{ADOU}=$ Asian Development Outlook Update, $\mathrm{GDP}=$ gross domestic product, $\mathrm{WEO}=\mathrm{World}$ Economic Outlook, WEOU = World Economic Outlook Update.

Source: Author's calculations. 


\section{Appendix 9: ADO Quarterly Updated GDP Forecast Errors, 2013-2016 Averages}
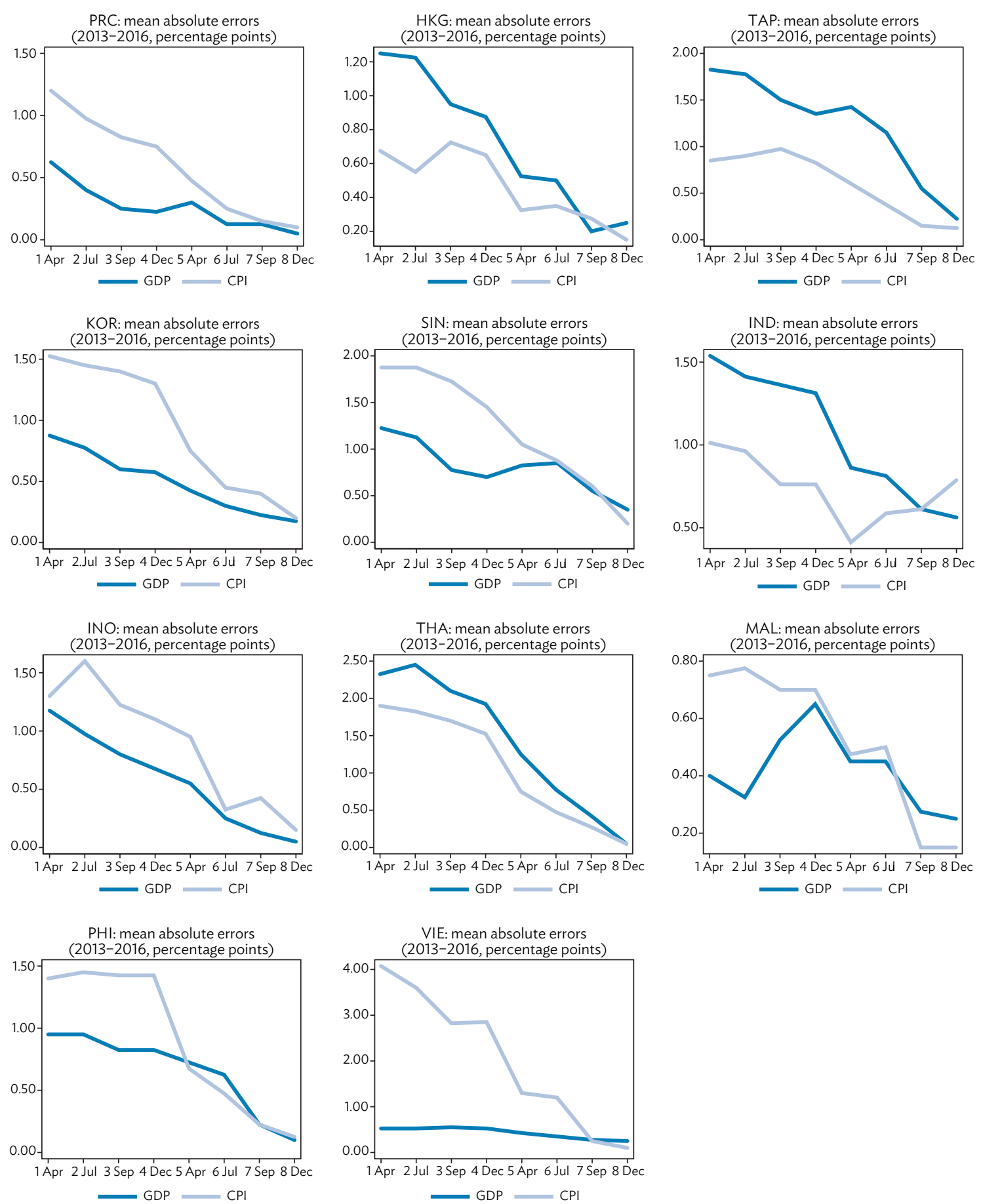

$\mathrm{ADO}=$ Asian Development Outlook; $\mathrm{CPI}=$ Consumer Price Index; GDP = gross domestic product; HKG = Hong Kong, China; IND = India; INO = Indonesia; $\mathrm{KOR}=$ Republic of Korea; $\mathrm{MAL}=$ Malaysia; $\mathrm{PHI}=$ Philippines; $\mathrm{PRC}=$ People's Republic of China; $\mathrm{SIN}=$ Singapore; TAP = Taipei,China; THA = Thailand; VIE = Viet Nam.

Source: Author's calculations. 


\section{REFERENCES}

Brier, Glenn W. 1950. "Verification of Forecasts Expressed in Terms of Probability." Monthly Weather Review 78 (1): 1-3.

Ferrarini, Benno. 2014. “Asian Development Outlook Forecast Skill.” ADB Economics Working Paper Series Number 386. Manila: Asian Development Bank. 


\section{Asian Development Outlook Forecast Accuracy 2007-2016}

This report assesses the accuracy of the Asian Development Outlook (ADO) growth and inflation forecasts for 43 Asian economies from 2007 to 2016. This is done in relation to the benchmark of World Economic Outlook (WEO) projections by the International Monetary Fund. Amid much heterogeneity across countries and years, it has been found that ADO and WEO projections overlap quite closely. Both are inaccurate, especially during crisis years, suggesting that forecasters struggle to come up with reliable forecasts. Projections only sharpen when additional data and evidence become available over time and are incorporated during quarterly revisions.

\section{About the Asian Development Bank}

ADB is committed to achieving a prosperous, inclusive, resilient, and sustainable Asia and the Pacific, while sustaining its efforts to eradicate extreme poverty. Established in 1966, it is owned by 67 members48 from the region. Its main instruments for helping its developing member countries are policy dialogue, loans, equity investments, guarantees, grants, and technical assistance. 